\title{
Tank Farm 100.1991 Surveillance and Waste Status Report for July 1991
}

Prepared for the U.S. Department of Energy Office of Environmental Restoration and Waste Management

\section{(2) Westinghouse \\ Hanford Company Richland, Washington}

Hanford Operations and Engineering Contractor for the

U.S. Department of Energy under Contract DE. AC06-87RL10930 


\section{LEGAL DISCLAIMER}

This report was prepared as an account of work sponsored by an agency of the United States Government. Neither the United States Government nor any agency thereof, nor any of their employees, nor any of their contractors, subcontractors or their employees, makes any warranty, express or implied, or assumes any legal liability or responsibility for the accuracy, completeness, or any third party's use or the results of such use of any information, apparatus, product, or process disclosed, or represents that its use would not infringe privately owned rights. Reference herein to any specific commercial product, process, or service by trade name, trademark, manufacturer, or otherwise, does not necessarily constitute or imply its endorsement, recommendation, or favoring by the United States Government or any agency thereof or its contractors or subcontractors. The views and opinions of authors expressed herein do not necessarily state or reflect those of the United States Government or any agency thereot.

This report has been reproduced from the best available copy. Available in paper copy and microliche.

Available to the U.S. Department of Energy

and its contractors from

Office of Scientific and Technical Information

P.O. Box 62

Oak Ridge, TN 37831

(615) 576.8401

Available to the public from the U.S. Department of Commerce National Technical Information Service

5285 Port Royal Road

Springfield, VA 22161

(703) 487.4650

Pinted in the United Stales of America 
WHC-EP- $-0182-40$

DE92 002234

\section{Tank Farm Surveillance and Waste Status Report for July 1991}

B. M. Hanlon

Date Published

September 1991

Prepared for the U.S. Department of Energy Office of Environmental Restoration and Waste Management

(2) Westinghouse

P.O. Box 1970

Hanford Compamy Richland, Washington 99352

Hanford Operations and Engineering Contractor for the

U.S. Department of Energy under Contract DE-AC06-87RL10930

Approved for Public Release 


\section{APPROVAL}

Prepared by: B. B. Hanlow $\frac{8 / 14 / 91}{\text { B. M. Hanton }}$ Engineer

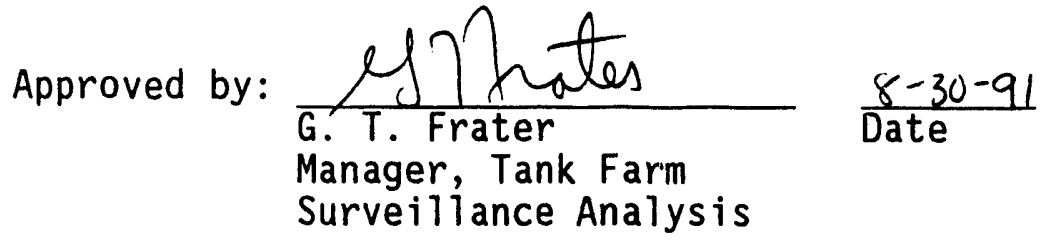




\title{
TANK FARM SURVEILLANCE AND WASTE STATUS
} SUMMARY REPORT FOR JULY 1991

\author{
B. M. Hanlon
}

\begin{abstract}
This report is the official inventory for radioactive waste stored in underground tanks in the 200 Areas at the Hanford Site. Data that depict the status of stored radioactive waste and tank vessel integrity are contained within the report. The intent of the report is to provide data on each of the existing 177 large underground waste storage tanks and 49 smaller catch tanks and special surveillance facilities, and to provide supplemental information regarding tank surveillance anomalies and ongoing investigations.
\end{abstract}


WHC-EP-0182-40

This page intentionally left blank. 


\section{CONTENTS}

SUMMARY

TANK STATUS

TANK INVESTIGATIONS

HIGHLIGHTS

Appendixes:

A. TANK AND EQUIPMENT CODE/STATUS DEFINITIONS ........... A-1

Tank and Equipment Code and Status Definitions . . . . . . A-3

B. TANK FARM CONFIGURATION, STATUS AND FACILITY CHARTS . . . . . . B-1

1 High-Level Waste Tank Configuration ........... B-3

2 Double-Shell Tank Instrumentation Configuration . . . . . . B-4

3 Single-Shell Tank Instrumentation Configuration ....... B-5

4 Double-Shell Tank Status ............... . B-7

5200 E Single-Shell Tank Status .............. . B-9

$6200 \mathrm{~W}$ Single-She11 Tank Status ............. B-11

7 Hanford Tank Farms Facilities Chart . . . . . . . . . . . B-13

c. MONTHLY SUMMARY ..................... c-1

1 Monthly Summary . . . . . . . . . . . . . . . . C C-3

2 Tank Use Summary . . . . . . . . . . . . . . . C-4

3 Inventory Summary by Tank Farm ............ C-5

4 Inventory and Status by Tank - Double-Sheli Tanks . . . . . . C C-6

5 Inventory and Status by Tank - Single-Shtil Tanks . . . . . . C-9

D. PERfORMANCE SUMMARY ................ D-1

1 Performance Summary ................. . . . D-3

E. LIQUID STATUS AND PUMPABLE LIQUID REMAINING IN TANKS . . . . . . . E-1

1 Liquid Status and Pumpable Liquid Remaining in Tanks . . . . . E-3

F. PUMPING RECORD ...................FF-1

1 Pumping Record ................... F-3

G. CATCH TANKS AND SPECIAL SURVEILLANCE FACILITIES ......... G-1

1 East and West Area Catch Tanks (Active) .......... G-3

2 East Area Catch Tanks (Inactive) ............. G-4

3 West Area Catch Tanks (Inactive) ............ G-5

H. LEAK VOLUME ESTIMATES . . . . . . . . . . . . . . H-1

1 Leak Volumes Estimated and Reported

Before 1989 (39 Tanks) . . . . . . . . . . . H-3

2 Leak Volumes Estimated in 1989 (27 Tanks) ......... H-5 


\section{LIST OF FIGURES}

1 Tank 101-SY Surface Level Readings . . . . . . . . . . . .

\section{LIST OF TABLES}

1 Watch List Tanks

2 Tanks Containing $>1,000$ gram mole of Ferrocyanide (Watch List Tanks) . . . . . . . . 5

3 Single-Shell Tanks with High Heat Loads $(>40,000 \mathrm{BTU} / \mathrm{hr}) \ldots 6$

4 Tanks with Potential for Hydrogen or Flammable Gas Accumulation Above the Flammability Limit (Watch List Tanks) . . . 7

5 Tanks Containing Potentially High Concentrations of Organic Salts $\geq 10$ Weight $\%$ TOC (Watch List Tanks) . . . . . . 8

6 Single-Shell Tanks Interim Stabilization and Isolations Schedule ...................... 9

7 Interim Stabilizations Status for Watch List Tanks . . . . . . 11

8 Double-Shell Tank Waste Type and Space Allocation . . . . . . . 12

\begin{tabular}{|l|c|c|}
\hline \multicolumn{2}{|c|}{ METRIC CONVERION CHART } \\
\hline 1 inch & $=2.54$ centimeters \\
\hline 1 foot & $=30.48$ centimeters \\
\hline 1 gallon & $=3.80$ liters \\
\hline 1 ton & $=0.90$ metric tons \\
\hline $1{ }^{\circ} \mathrm{F}$ & $=\left(\frac{9}{5}{ }^{\circ} \mathrm{C}\right)+32$ \\
\hline & $\begin{array}{r}\text { Btu/h }=2.930711 \text { E-01 watts } \\
\text { (International Table) }\end{array}$ \\
\hline
\end{tabular}


WHC-EP-0182-40

TANK FARM SURVEILLANCE AND WASTE STATUS SUMMARY

REPORT FOR JULY 1991

SUMMARY

Note: Changes from the previous month are in bold print.

TANK STATUS

\begin{tabular}{|c|c|c|}
\hline Category & Quantity & Date of Last Change \\
\hline In-Service Tanks ${ }^{c}$ & 28 double-she 11 & $10 / 86$ \\
\hline Out-of-Service Tanks ${ }^{\mathbf{a}}$ & 149 single-shell & $07 / 88$ \\
\hline Assumed-Leaker Tanks & 66 single-sine 11 & $09 / 88$ \\
\hline Interim-Stabilized Tanks $s^{b, d}$ & 105 single-shell & $09 / 90$ \\
\hline Interim-Isolated Tankse & 94 single-shell & $09 / 90$ \\
\hline
\end{tabular}

a A11 149 single-shell tanks were removed from service (i.e., no longer authorized to receive waste) as of November 21, 1980.

b of the 105 tanks classified as interim stabilized, 56 have been 1isted as "questionab?e integrity" or "confirmed leakers" in past documents.

"Five double-shell tanks listed as "in service" are currently not receiving waste because of inclusion on the Hydrogen Watch List.

of the 48 single-shell tanks on Watch Lists, 21 have been Interim Stabilized. Isolated.

ef the 48 single-shell tanks on Watch Lists, 16 have been Interim

\section{TANK INVESTIGATIONS}

Tank 241-SY-101. The surface level within this tank continues to fluctuate. The surface level increase/decrease phenomena has been observed since 1981 , and is attributed to the buildup and release of gas beneath the crusted surface. An investigation into solutions to the slurry growth problems is ongoing. Multiple Event Fact Sheets, a Critique Report, Occurrence Reports Nos. 77-64, 77-92, 77-175, 77-207, 78-16, 79-11, Discrepancy Reports, and Unusual Occurrence Reports have been issued. The Food Instrument Corporation (FIC) gauge, manual tape, and radar gauge measurement devices showed an upward trend in the surface level measurement during the month of June. The FIC and manual tape surface level measurement anomalies were seen June 11 to June 14 and June 19 to June 22, 1991. The radar gauge did not show these apparent anomalies, and is most likely the best representation of the surface level during the later part of June. The FIC surface level measurement showed 407.8 in. On July 7, and 409.45 in. on July 8,1991 . This increase is attributed to the uneven crust where the FIC surface level measurements are being taken. Photographs of the FIC show measurements being taken in and out of dimples in the uneven curst. The radar gauge also did not show these apparent anomalies. There was a very slow increase to 409.5 in. on July 31 , 1991. 
WHC-EP-0182-40

\section{Potential or Assumed Leaks}

Catch Tank 241-S-302-A. Surface level measurement decreases have been observed after noted increases attributed to rain. The decreases in this tank could not be accounted for and were assumed to be indicative of a leak. Event Fact Sheet TF-EFS-90-042 was issued June 8, 1990. Pumping of the tank commenced June 14, 1990, and Unusual Occurrence Report WHC-U0-90-23-TF-05 was issued June 21, 1990. Pumping was completed on July 13, 1990. At that time the surface level measurement device was touching on solids (surface level was 14.20 in.), and less than $400 \mathrm{gal}$ of liquid remained in a visible pool. Total gallons pumped was 2,660. Occurrence Report WHC-90-B013-TFarm, an update to WHC-U0-90-23-TF-05 (TF-EFS-90-042), was issued November 12, 1990. The Westinghouse Hanford Company and U.S. Army Corps of Engineers developed a plan to perform a temporary repair of this tank in order to support required transfers of facilities waste to the tank farms. This temporary repair, involving grout being added to the tank, would allow near-term transfers to proceed pending planned replacement with a new tank. The pouring of the first of three layers of grout was accomplished on February 26, 1991. The remaining pours were completed and 4,400 gal of water were added on March 20 to facilitate leak testing. Upon completion of the leak testing, the ultrasonic leak test data and the FIC gauge data was analyzed, and it was determined that the slow decrease in the liquid level was not the effect of temperature variations or evaporation. It was concluded that the catch tank is still leaking. On April 16, 1991, the tank was pumped to remove water that was added to perform the leak test. New criteria limits have been established for the tank, and the surface level will not be allowed to increase more than $0.5 \mathrm{in}$. from the baseline of $54.0 \mathrm{in}$. without attempting to pump. On June 4 , 1991, the surface level increased to $54.7 \mathrm{in.}$, exceeding the 0.5 -in. increase criteria by 0.2 in. Occurrence Report RL-WHC-TANKFARM-191-1018 was issued June 5, 1991. The increase was attributed to an intrusion of approximately $90 \mathrm{gal}$ of water that had leaked from a faulty hose connection to a diversion box which drains directly into S-302-A. This occurred during maintenance activities to install a replacement catch tank for S-302-A. On June 12, 1991, the tank was pumped. The surface level measurement remained stable at 54.5 in. through July 1991. Preliminary work is in progress to replace this catch tank. The new tank is expected to be in service before September 30, 1991 .

\section{Potential or Assumed Intrusions:}

The following tanks are on report for potential in-leakage (intrusions) from known/unknown sources.

Tank 241-TX-115. The Liquid Observation Well (LOW) scans revealed an Interstitial Liquid Leve 7 (ILL) increase in excess of the established $0.4 \mathrm{ft}$. increase criteria in May 1987. Comparison of past and present in-tank photographs show no significant change in surface conditions or obvious evidence of intrusion. An Event Fact Sheet was issued on January 9, 1990. The ILL showed an increase of $0.4 \mathrm{ft}$ on March 1, 1991. The increase was verified on March 11, 1991. Engineering Testing is conducting an intrusion investigation for this tank. These LOWs are monitored quarterly, alternating every six weeks with the neutron and gamma probes. The ILL showed no further increase on the scan taken June 7, 1991. 
Tank 241-S-107. A slow increase in the surface level has been observed since May 1987, but it has not exceeded the 2.00-in. increase criteria. This tank now appears on the. Alert List.

\section{HIGHLIGHTS}

\section{Saltwell Pumping}

Jet pumping in Tanks 102-BY and 109-BY continues. Changes in liquids and solids can be found in Appendix C (Inventory and Status by Tank, Single-Shell Tanks) and the Changes section immediately following Appendix $C$.

Changes to the Summary Report:

1. Monthiy Summary

Table 1 (Watch List Tanks) has been added. This table lists the tanks identified as being on the Watch List.

Tables 2 through 5 (temperatures for tanks containing ferrocyanide, hydrogen, organic salts or having high heat loads) have been modified. These tables all now have columns for ASSUMED LEAKED DATED (or SOUND) and INTERIM STABILIZED DATE (or Not Applicable).

Former Table 5 (Single-Shell Tanks on Active Ventilation) has been deleted. A statement has been added to the new Table 5 (Single-Shell Tanks with High Heat Loads) that "all high heat load tanks are on active ventilations." Failure of any of the cooling systems for these tanks will be reported in the Summary section.

Figure 2 (Double-Shell Tanks Overall Waste Flow and Disposal) has been deleted. The figure has appeared in the document for four months and is no longer needed for reference. 


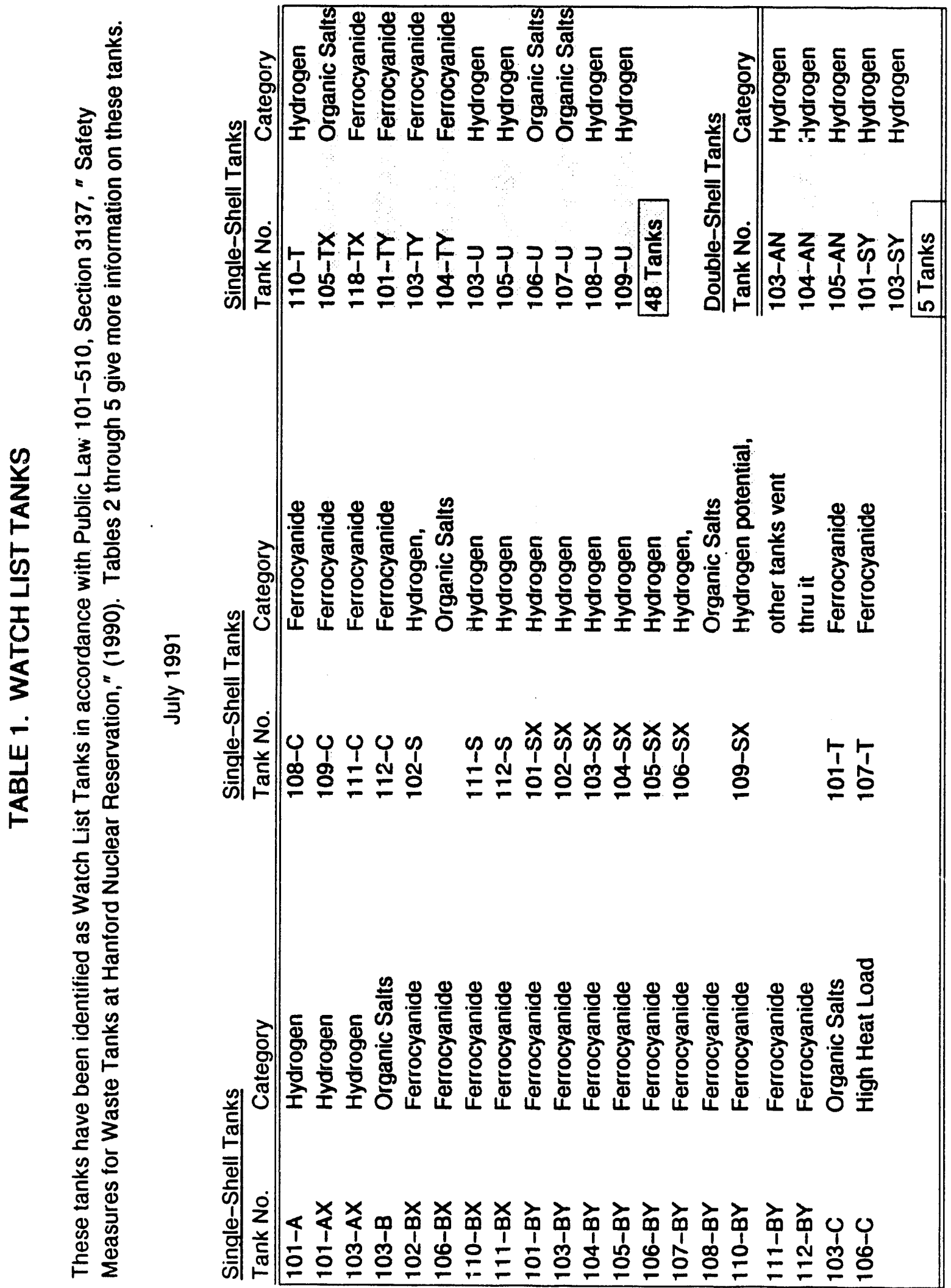


WHC-EP-0182-40

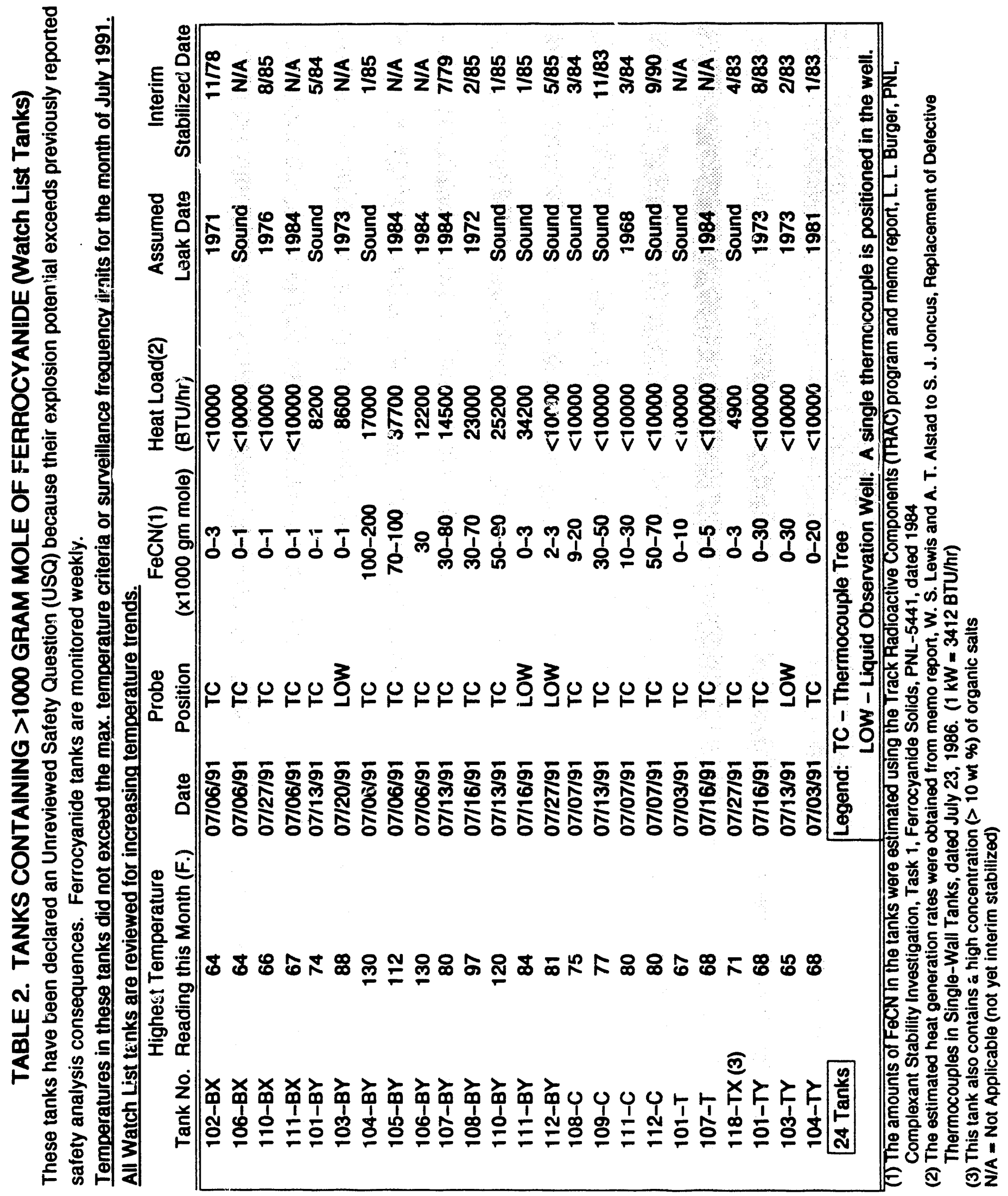


WHC -EP-0182-40

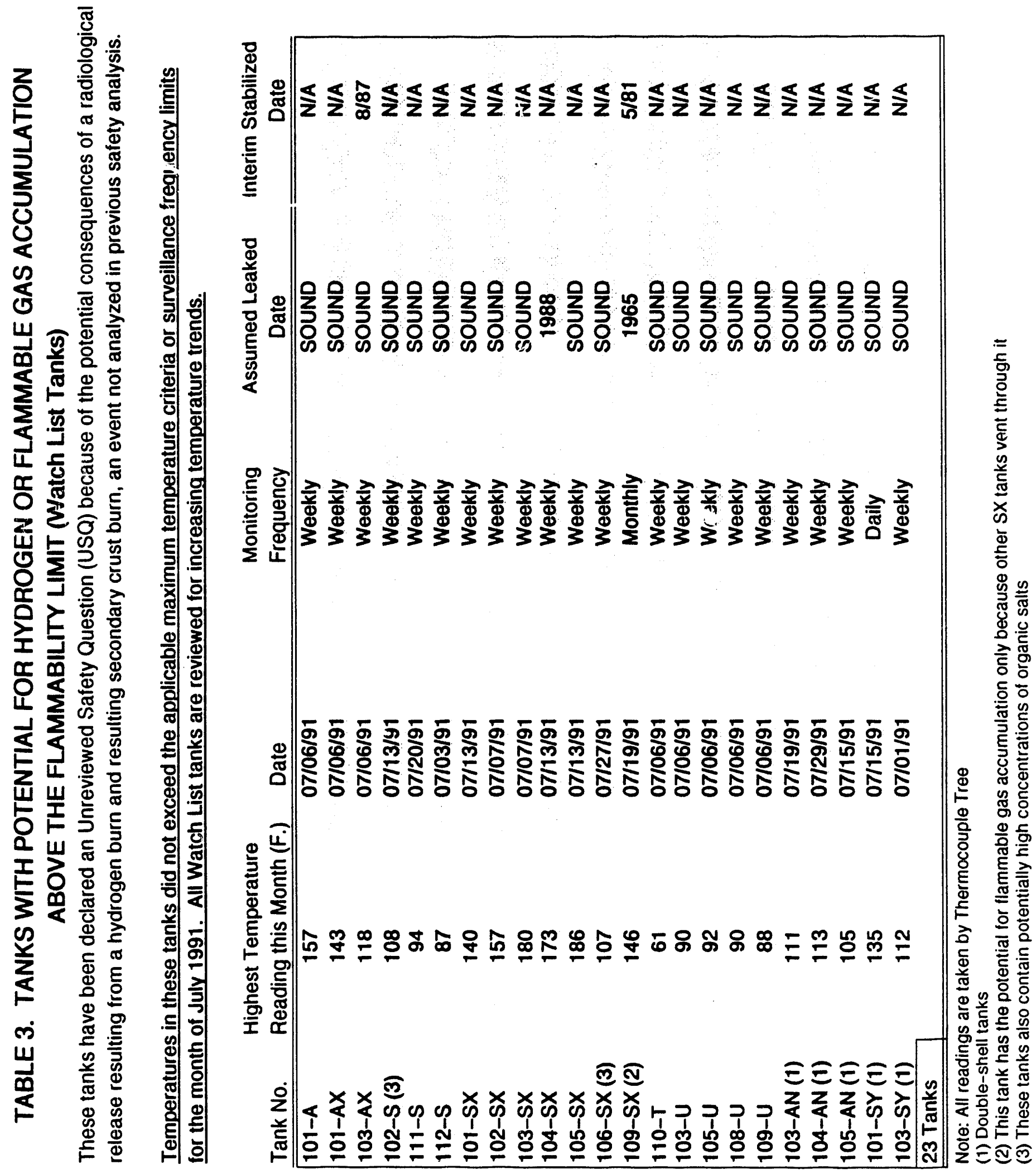




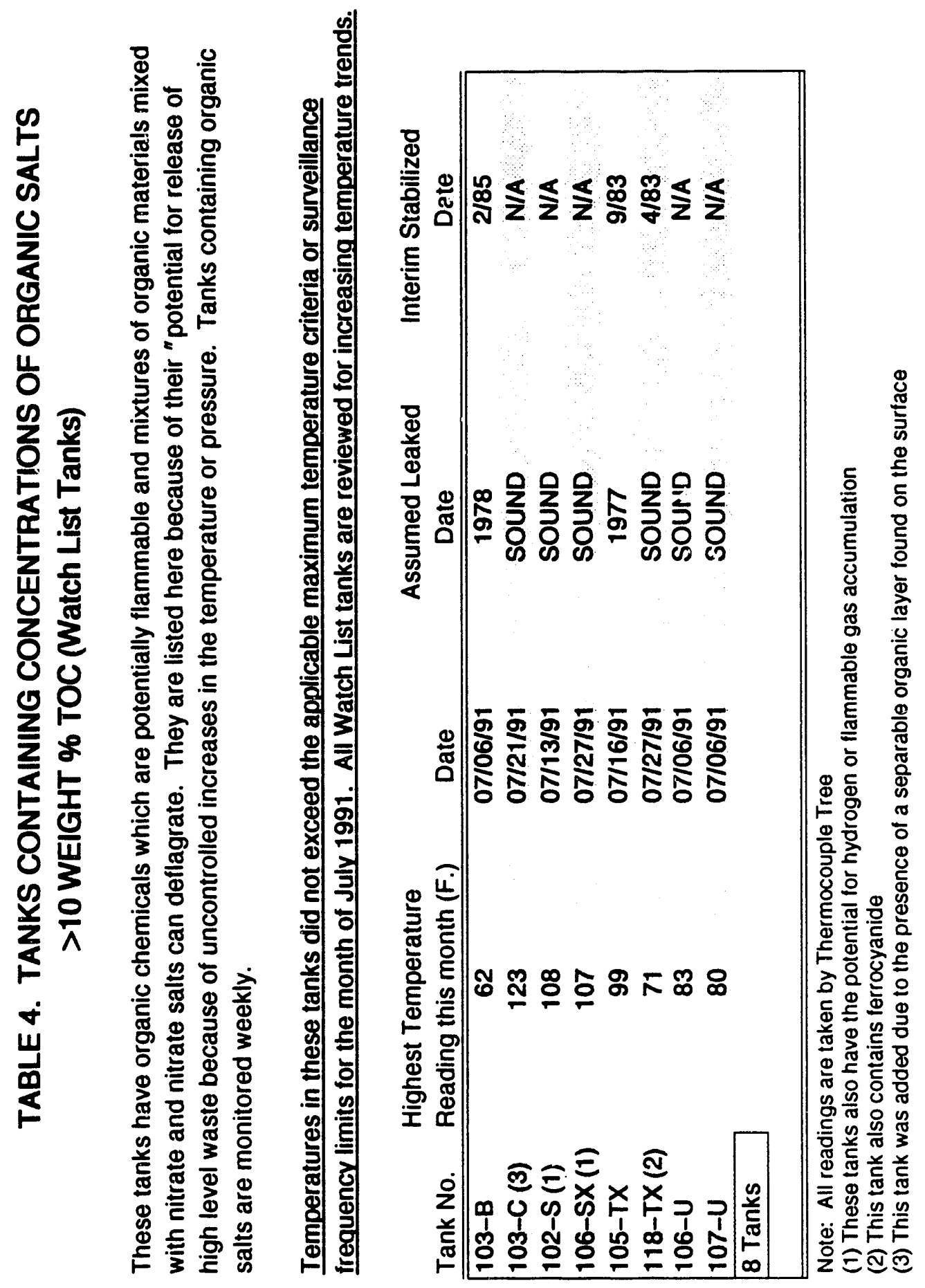


WHC -EP-0182-40

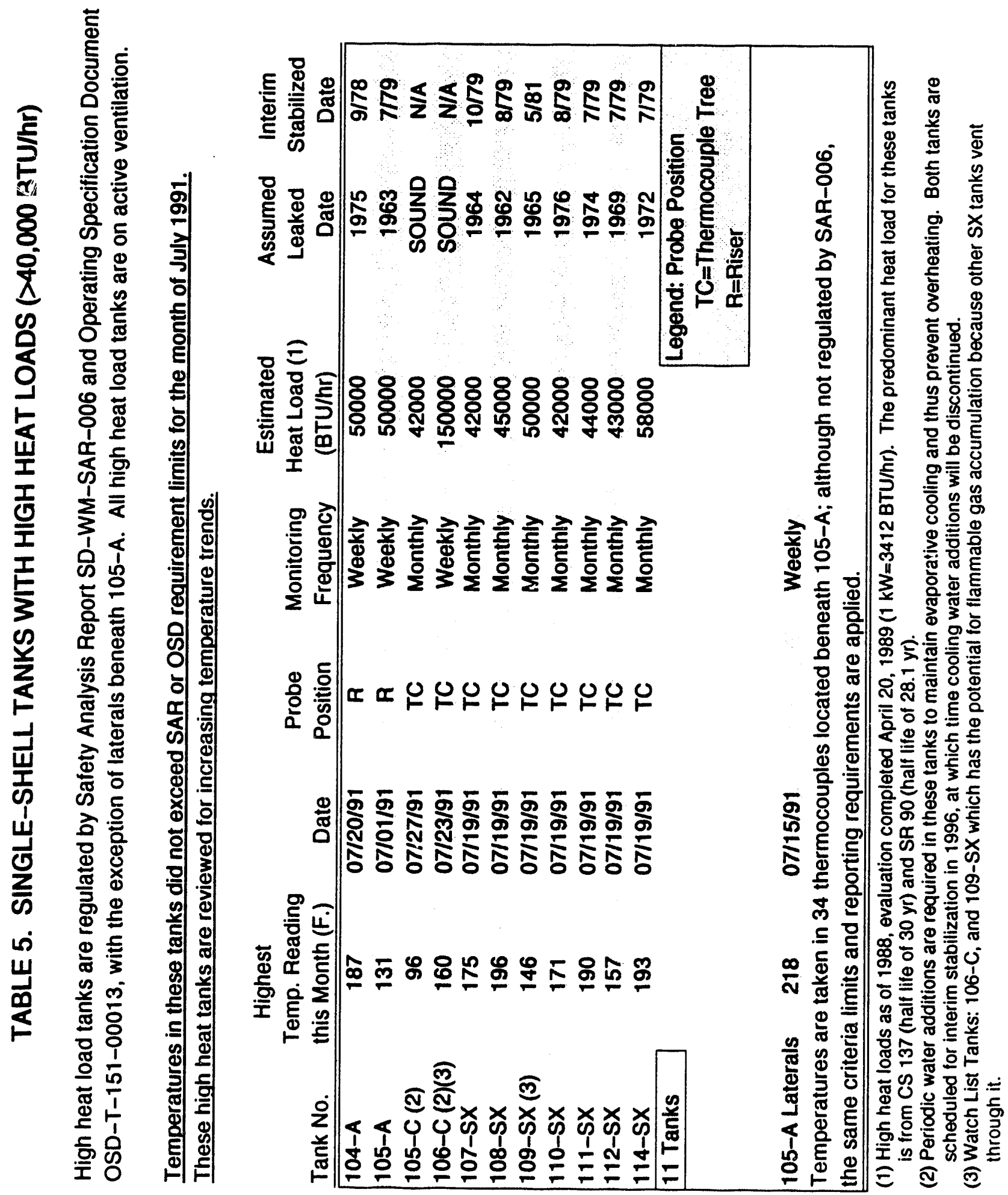




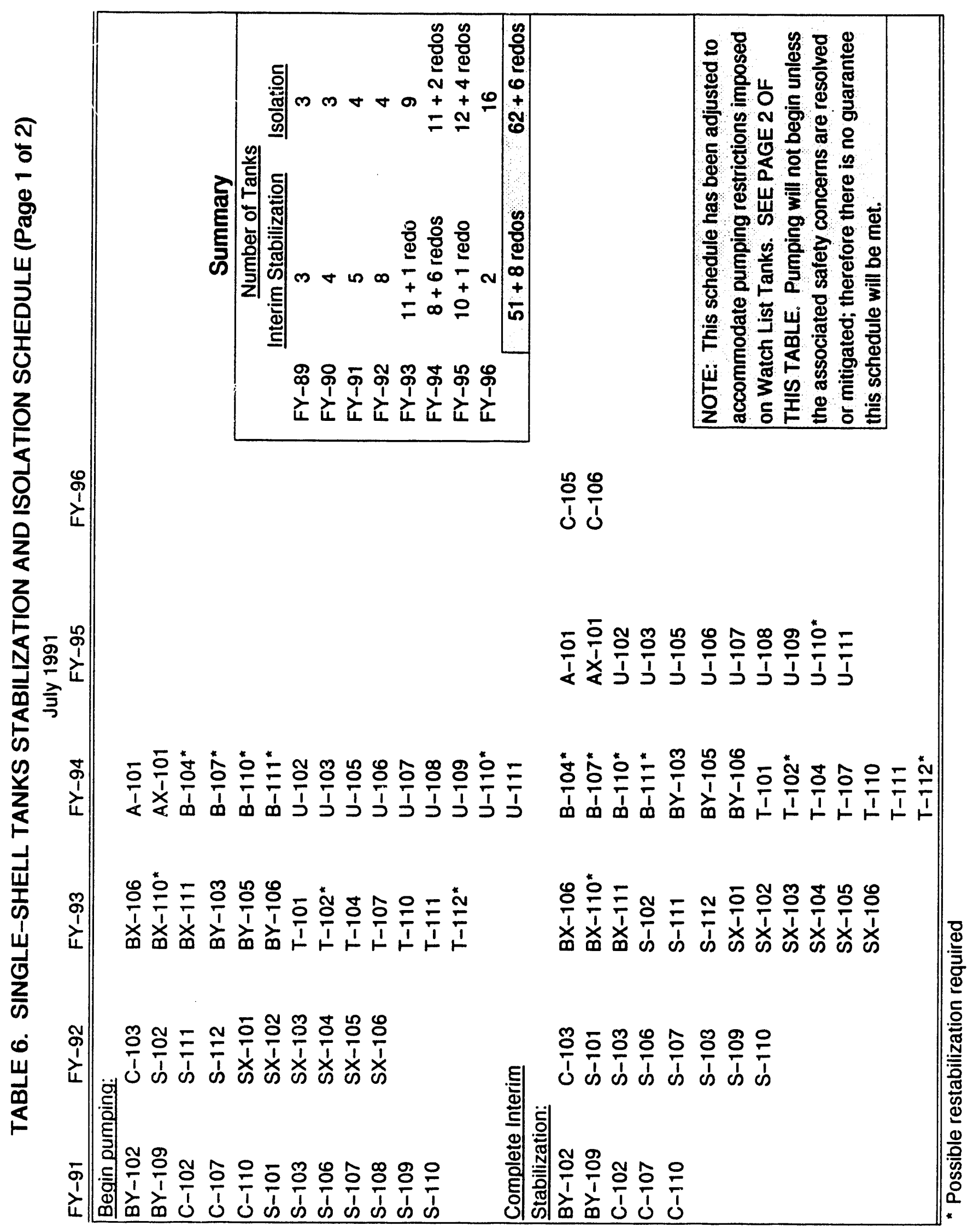


WHC-EP-0182-40

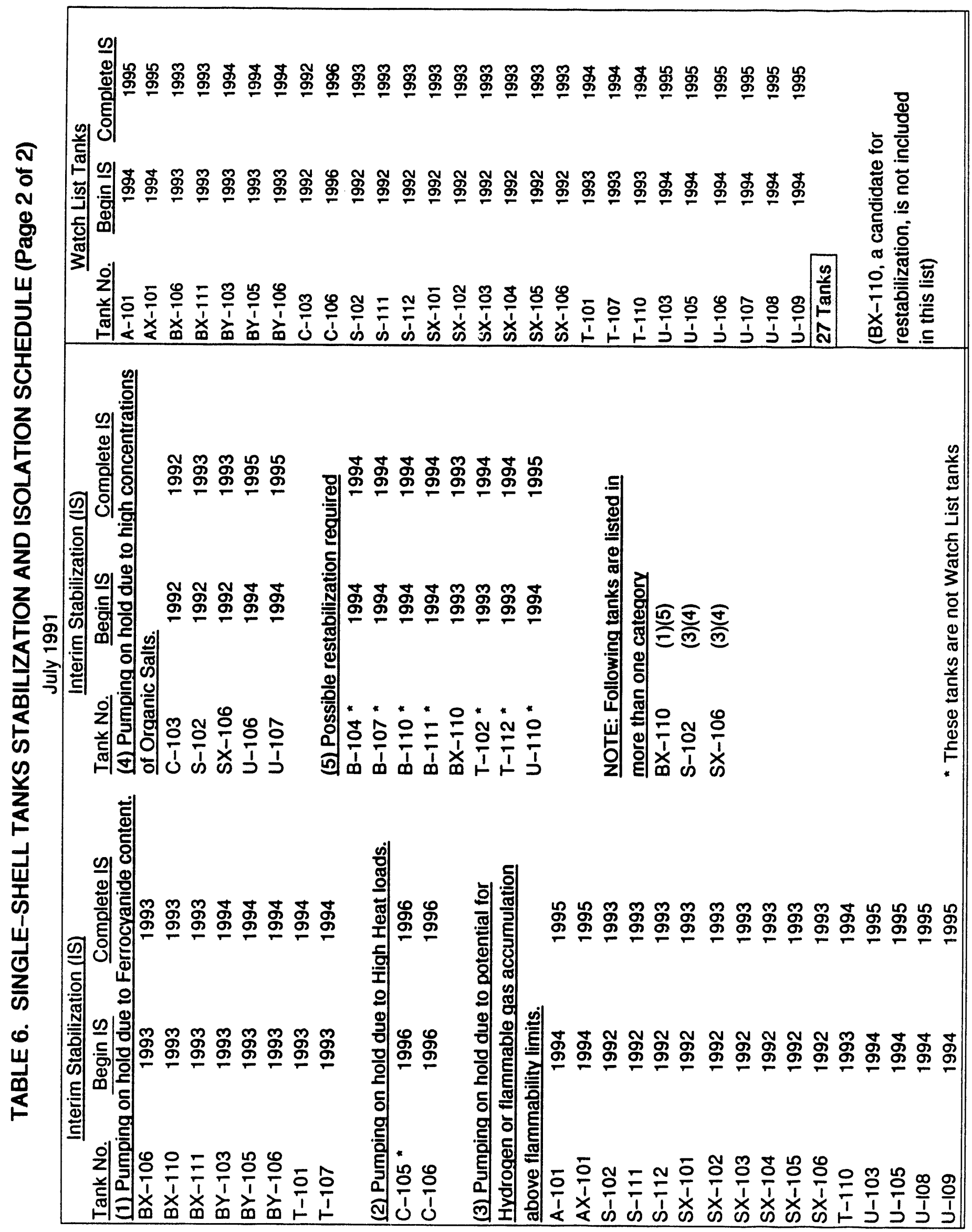


WHC-EP-0182-40

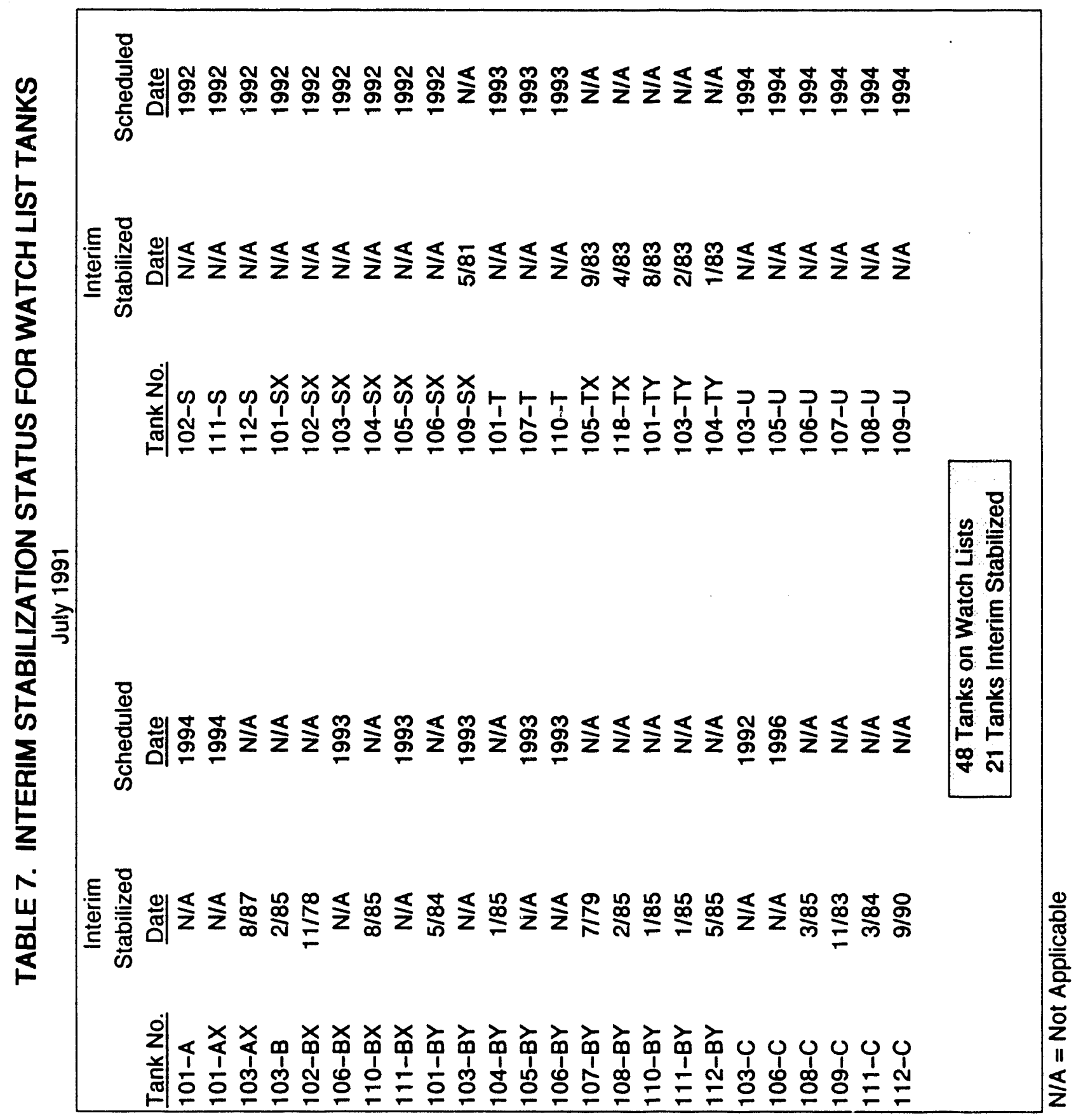




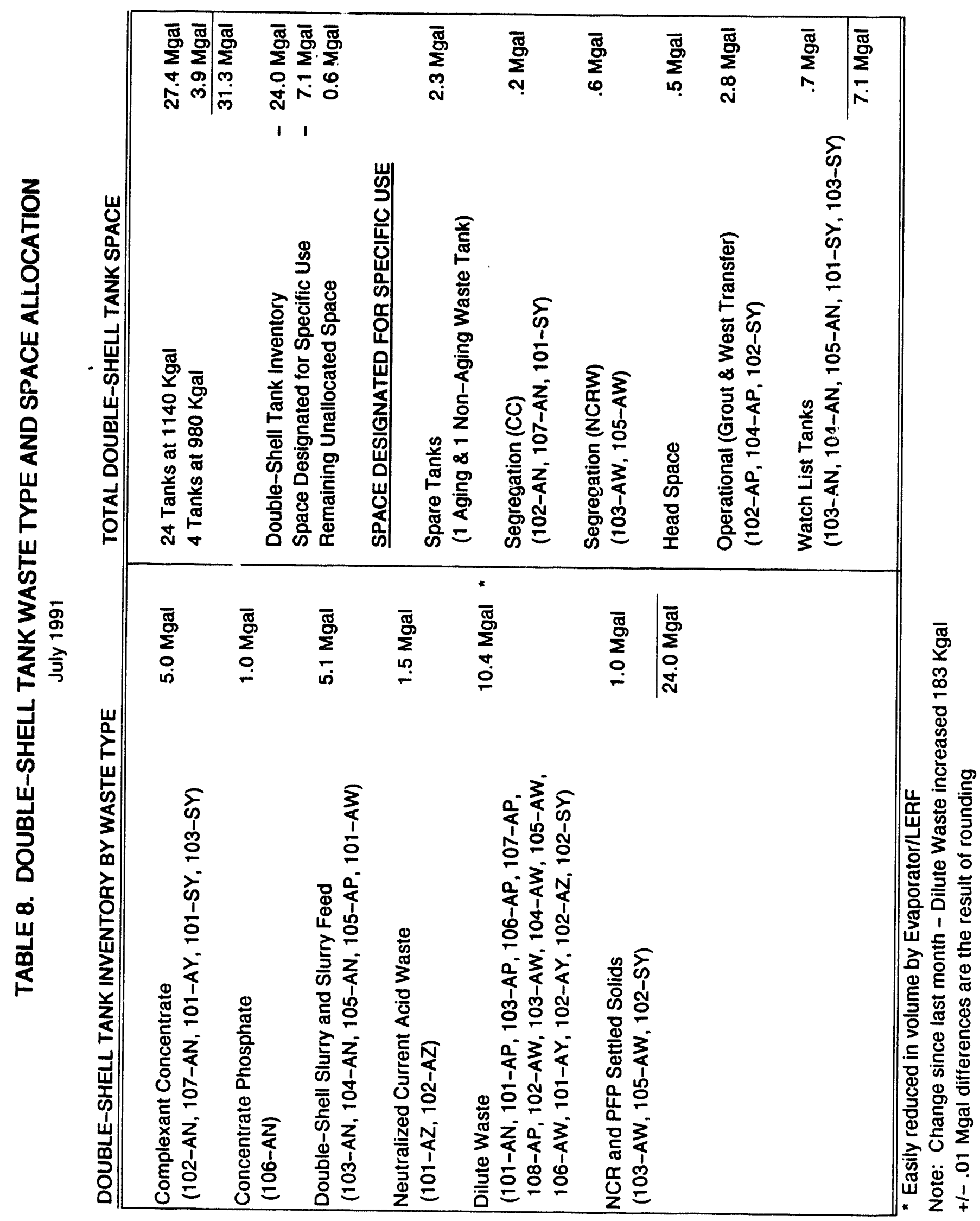




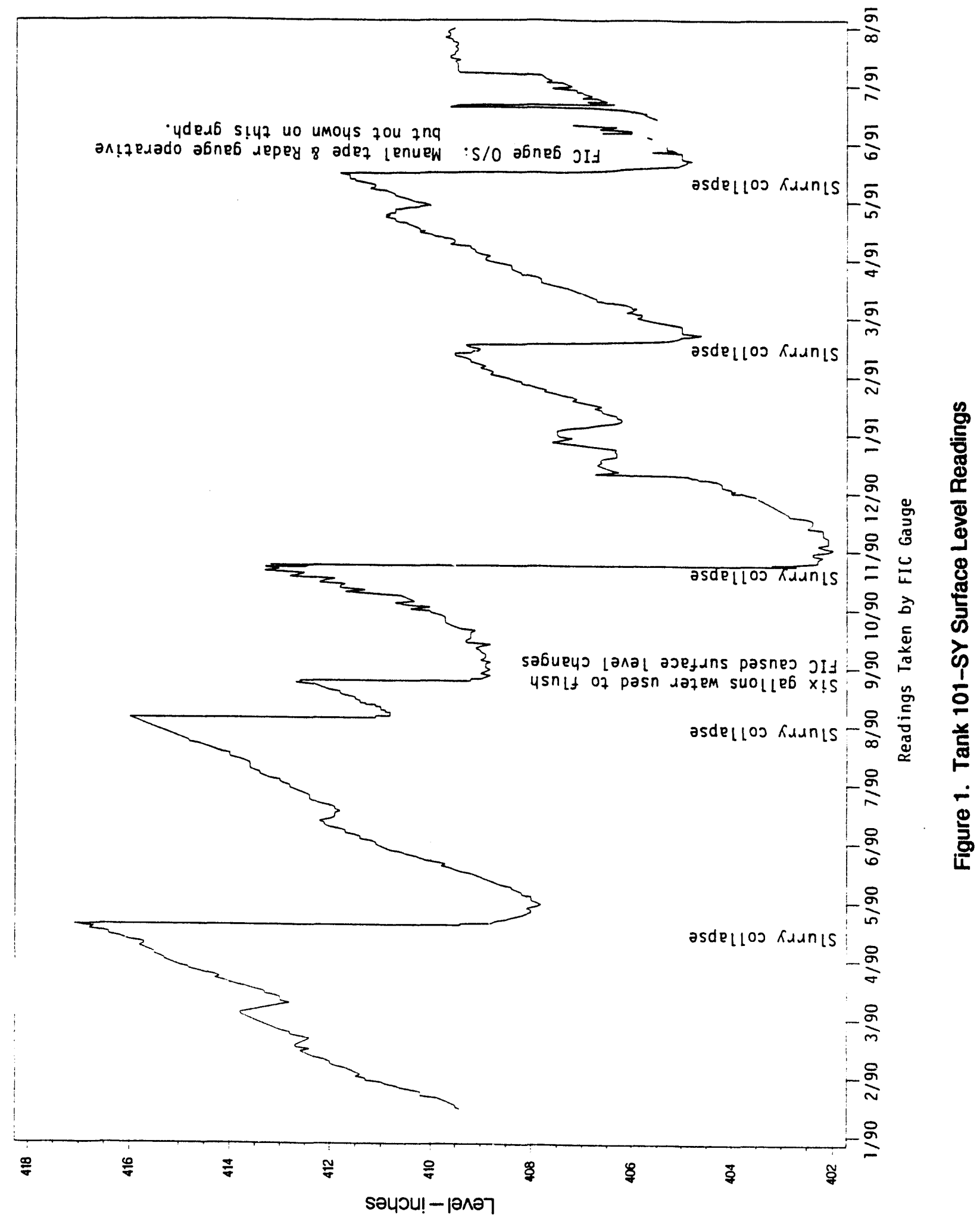


WHC-EP-0182-40

This page intentionally left blank. 
WHC-EP-0182-40

\section{APPENDIX A}

\section{TANK AND EQUIPMENT CODE/STATUS DEFINITIONS}


WHC-EP-0182-40

This page intentionally left blank. 
WHC-EP-0182-40

\section{TANK AND EQUIPMENT CODE/STATUS DEFINITIONS}

July 1991

\section{TANK STATUS CODES}

\section{WASTE TYPE}

$\begin{array}{ll}\text { AGING } & \text { Aging Waste (Neutralized Current Acid Waste [NCAW]) } \\ \text { CC } & \text { Complexant Concentrate Waste } \\ \text { CP } & \text { Concentrated Phosphate Waste } \\ \text { DC } & \text { Dilute Complexed Waste } \\ \text { DN } & \text { Dilute Non-Complexed Waste } \\ \text { DSS } & \text { Double-She11 Slurry } \\ \text { DSSF } & \text { Double-She11 Slurry Feed } \\ \text { NCPLX } & \text { Non-Complexed Waste } \\ \text { PD/PN } & \text { Plutonium-Uranium Extraction (PUREX) Neutralized Cladding } \\ & \text { Removal Waste (NCRW) transuranic Waste (TRU) } \\ \text { PT } & \text { Plutonium Finishing Plant (PFP) TRU Solids }\end{array}$

TANK USE (DOUBLE-SHELL TANKS ONLY)

$\begin{array}{ll}\text { CWHT } & \text { Concentrated Waste Holding Tank } \\ \text { DRCVR } & \text { Dilute Receiver Tank } \\ \text { EVFD } & \text { Evaporate Feed Tank } \\ \text { GRTFD } & \text { Grout Feed Tank } \\ \text { SRCVR } & \text { Slurry Receiver Tank }\end{array}$

2. SOLID AND LIQUID VOLUME DETERMINATION METHODS
F Food Instrument Company (FIC) Automatic Surface Leve1 Gauge
$M \quad$ Manual Tape Surface Level Gauge
$P \quad$ Photo Evaluation
S Sludge Level Measurement Device

\section{DEFINITIONS}

\section{WASTE TYPES}

Aging Waste

(AGING)

Concentrated

Complexant (CC)

Concentrated Phosphate Waste (C.P)

Dilute Complexed Waste (DC)
High level, first cycle solvent extraction waste from the PUREX plant (NCAW).

Concentrated product from the evaporation of dilute complexed waste.

Waste originating from the decontamination of $100 \mathrm{~N}$ Area reactor. Concentration of this waste produces concentrated phosphate waste.

Characterized by a high content of organic carbon including organic complexants: ethylenediametetraacetic acid (EDTA), citric acid, $\mathrm{N}$-(hydroxyethylethylenediaminetriacetic acid) (HEDTA), and 
Dilute

Non-Complexed

Waste (DN)

Double-Shell

STurry (DSS)

Double-Shell

Slurry Feed (DSSF)

Non-complexed

(NCPLX)

PUREX Decladding (PD/PN)

PFP TRU Solids (PT)

Drainable

Interstitial

Liquid (DIL)

Supernatant

WASTE STATUS

In-Service Tank

Out-of-Service

Tank iminodiacetate (IDA) being the major compiexants used. Main sources of DC waste are saltwell liquid inventory.

Low activity liquid waste originating from $T$ and $S$ Plants, the 300 and 400 Areas, PUREX facility (decladcing supernatant and miscellaneous wastes), $100 \mathrm{~N}$ Area (sulfate waste), B Plant, saltwells, and PFP (supernatant).

Waste evaporated almost to its sodium aluminate saturation boundary or $6.5 \mathrm{M}$ hydroxide in the evaporator. For reporting purposes, DSS is considered a solid.

Waste evaporated just before reaching the sodium aluminate saturation boundary or $6.5 \mathrm{M}$ hydroxide in the evaporator. This form is not as concentrated as DSS.

General waste term applied to all Hanford site liquors not identified as complexed.

PUREX Neutralized Cladding Removal Waste (NCRW) is the solids portion of the PUREX plant neutralized cladding removal waste stream; received in Tank Farms as a slurry. Classified as transuranic (TRU) waste.

TRU solids from West Area cperations.

Interstitial liquid that is not held in place by capillary forces, and will therefore migrate or move by gravity.

The liquid above the solids in waste storage tanks.

The waste classification of a tank being used, or planned for use, for the storage of liquid (in excess of a minimum supernatant liquid hee1) in conjunction with production and/or waste processing.

A tank which does not meet the definition of an inservice tank. Before September 1988, these tanks were defined as inactive in this report. (Note: All single-shel! tanks [SST] are out of service.) 


\section{STABILIZATION (Single-Shell Tanks only)}

Interim

Stabilized

(IS)
A tank which contains less than $50,000 \mathrm{gal}$ of drainable interstitial liquid and less than 5,000 gal of supernatant 1 iquid.

\section{ISOLATION (Single-Shell Tanks only)}

Partially

Interim Isolated

(PI)

Interim Isolated (II)

\section{TANK INTEGRITY}

Sound

Assumed Leaker

\section{TANK INVESTIGATION}

Intrusion

A term used to describe the infiltration of 1 iquid into a waste tank.

The integrity classification of a waste storage tank for which surveillance data indicate no loss of liquid attributed to a breach of integrity.

The integrity classification of a waste storage tank for which surveillance data indicate a loss of liquid attributed to a breach of integrity.

\section{SURVEILLANCE INSTRUMENTATION}

Drywells

Laterals
Drywells are vertical carbon steel casings positioned radially around SSTs. Periodic monitoring is done by gamma radiation or neutron sensors :o obtain scan profiles of radiation or moisture in the soil as a function of well depth, which could be indicative of tank. These wells range between 50 and $250 \mathrm{ft}$ in depth, and are monitored between the range of 50 to $150 \mathrm{ft}$. The wells are sealed when not in use.

Laterals are horizontal drywells positioned under single-shell waste storage tanks to detect radionuclides in the soil which could be indicative of tank leakage. These drywells are monitored by radiation detection probes. Laterals are 4-in. inside diameter steel pipes located 8 to $10 \mathrm{ft}$ below 
Surface Levels

illtomatic FIC

Annulus

Liquid Observa-

tion Well (LOW)

Thermocouple (TC) the tank's concrete base. There are three laterals per tank. Laterals are located only in $A$ and $S X$ farms.

The surface level measurements in all waste storage tanks are monitored by manual or automatic conductivity probes, and recorded and transmitted or inputted to the Computer Automated Surveillance System (CASS).

An automatic waste surface level measurement device is manufactured by the Food Instrument Company (FIC). The instrument consists of a conductivity electrode (plummet) connected to a calibrated steel tape, a steel tape reel housing and a controller that automatically raises and lowers the plummet to obtain a waste surface level reading. The controller can provide a digital display of the data and also transmit the reading to the CASS. Some tanks have gauges connected to CASS and others are read manualiy.

The annulus is the space between the inner and outer shells on DSTs. Drain channels in the insulating and/or supporting concrete carry any leakage to the annulus space where conductivity probes are installed. Alarms from the annunciators are received by CASS. Continuous Air Monitoring (CAM) alarms are also located in the annulus. The annulus conductivity probes and radiation detectors are the primary means of leak detection for all DSTs.

In-tank liquid observation wells are used for monitorirg the interstitial liquid level (ILL) in single-shell waste storage tanks. The wells are constructed of fiberglass, tefzel-reinforced epoxypolyester resin, sized to extend to within 1 in. of the bottom of the tank steel liner. They are sealed at their bottom ends and have a nominal outside diameter of $3.5 \mathrm{in}$. Three probes are used to monitor changes in the ILL: acoustic; gamma; and neutron, which can indicate intrusions or leakage by increases or decreases in the ILL. There are 58 LOWs (57 are in operation) installed in SSTs that contain or are capable of containing greater than 50,000 gal of drainable interstitial 1iquid, and in two DSTs only. The LOWs installed in two DSTs (102-SY and 103-AW Tanks on1y) are used for special surveillance purposes onty.

A thermocouple is a thermoelectric device used to measure temperature. More than one thermocouple on a device (probe) is called a thermocouple tree. In 
In-tank

Photography
DSTs there may be one or more thermocouple trees in risers in the primary tank. In addition, in DSTs only, there are thermocouple elements installed in the insulating concrete, the lower primary tank knuckle, the secondary tank concrete foundation, and in the outer structural concrete. These monitor temperature gradients within the concrete walls, bottom of the tank, and the domes. In SSTs, there may be one or more thermocouple trees installed directly in a tank. A single thermocouple may be installed in a riser, or lowered down an existing riser or LOW. There are also thermocouple laterals beneath Tank 105-A in which temperature readings are taken in 34 thermocouples.

In-tank photographs are taken to aid in resolving in-tank measurement anomalies and determine tank integrity. Photographs help determine sludge and liquid levels by visual examination.

\section{INVENTORY AND STATUS BY TANK - COLUMN CALCULATIONS (SINGLE-SHELL TANKS)}

\section{COLUMN HEADING}

Total Waste Solids Volume plus Supernatant liquid.

Supernatant Drainable Liquid Remaining minus Drawlable Interstitial. Liquid

Drainable Interstitial Supernatant is usually derived by subtracting the solids level measurement from the liquid level measurement.

Drainable Liquid Remaining minus Supernatant.

Drainable Interstitial Liquid is calculated based on the saltcake and sludge volumes, using average porosity values or actual data for each tank, when available.

Total Jet

Pumped

Cumulative total pumped 1979 to date.

Drainable

Liquid

Remaining

Pumpable

Liquid

Remaining

Sludge

Supernatant plus Drainable Interstitial.

Drainable Liquid Remaining less undrainable heel volume.

Solids formed during sodium hydroxide additions to waste. Sludge usually was in the form of suspended solids when the waste was originally received in the tank from the waste generator. In-tank photographs may be used to estimate the volume. 
Saltcake $\quad$ Results from crystalization and precipitation after concentration of liquid waste, usually in an evaporator. If saltcake is layered over siudge, it is only possible to measure total solids volume. In-tank photographs may be used to estimate the saltcake volume.

Solids Volume Indicates the latest update of any change in the solids volume.

Solids Update Indicates the source or basis of the latest solids Source - See volume update.

Footnote

Last Photo Date of latest in-tank photographs taken.

Date

Change Since Indicates any change made since the previous month. Last Monthly Explanation for the change follows the Inventory and Report Status by Tank section. 
WHC-EP-0182-40

APPENDIX B

TANK FARM CONFIGURATION, STATUS AND FACILITY CHARTS 
WHC-EP-0182-40

This page intentionally left blank. 


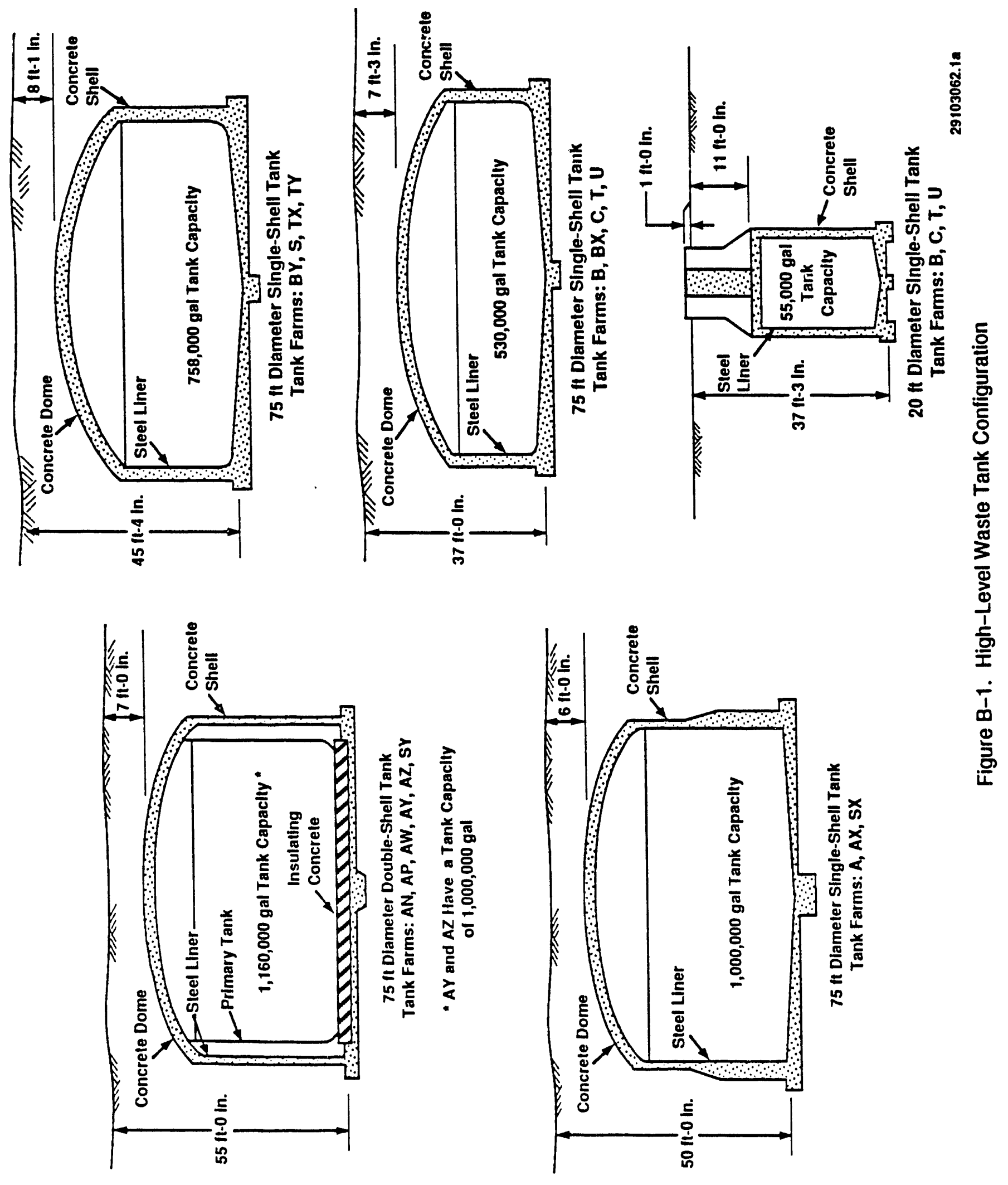




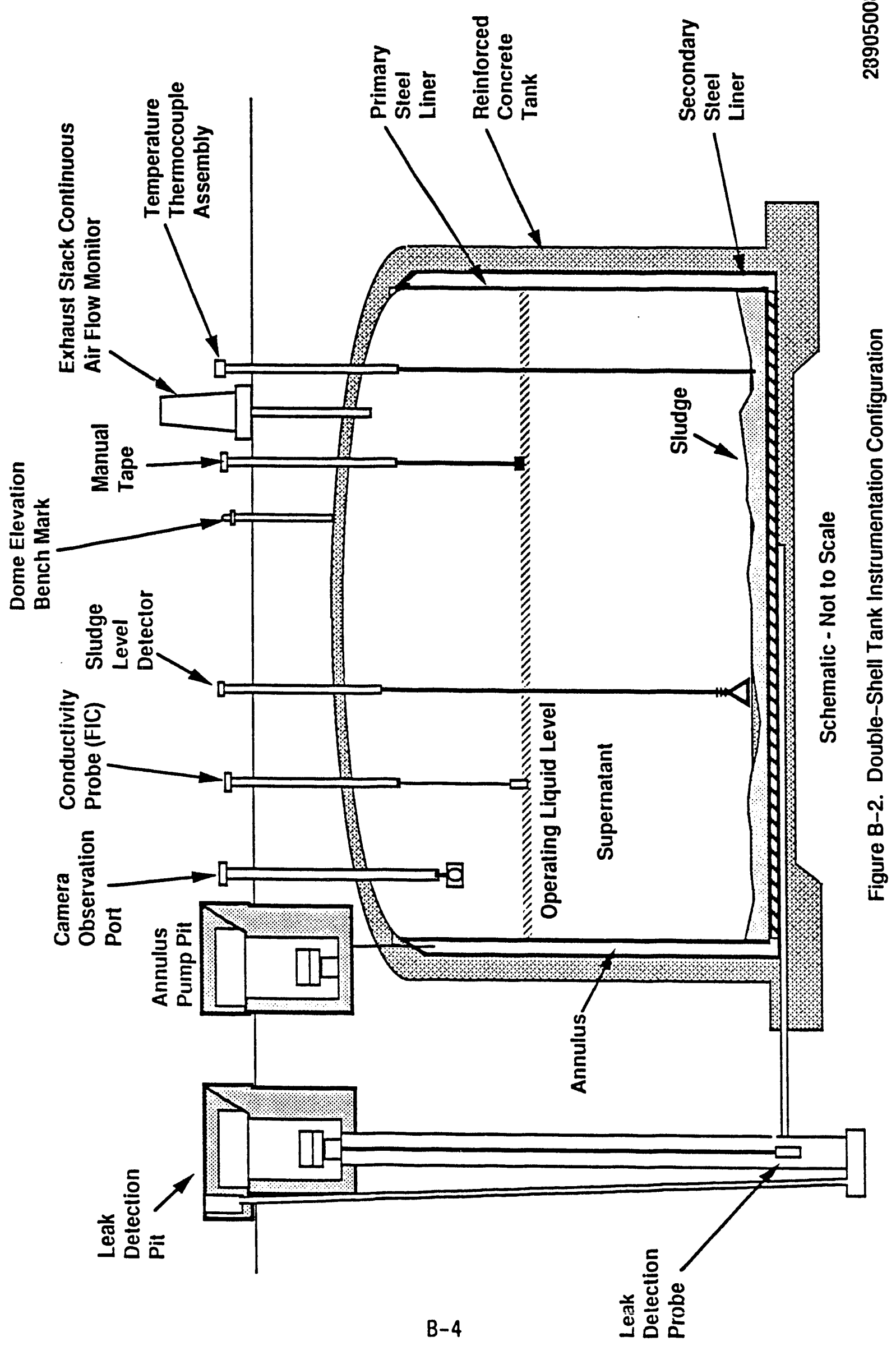




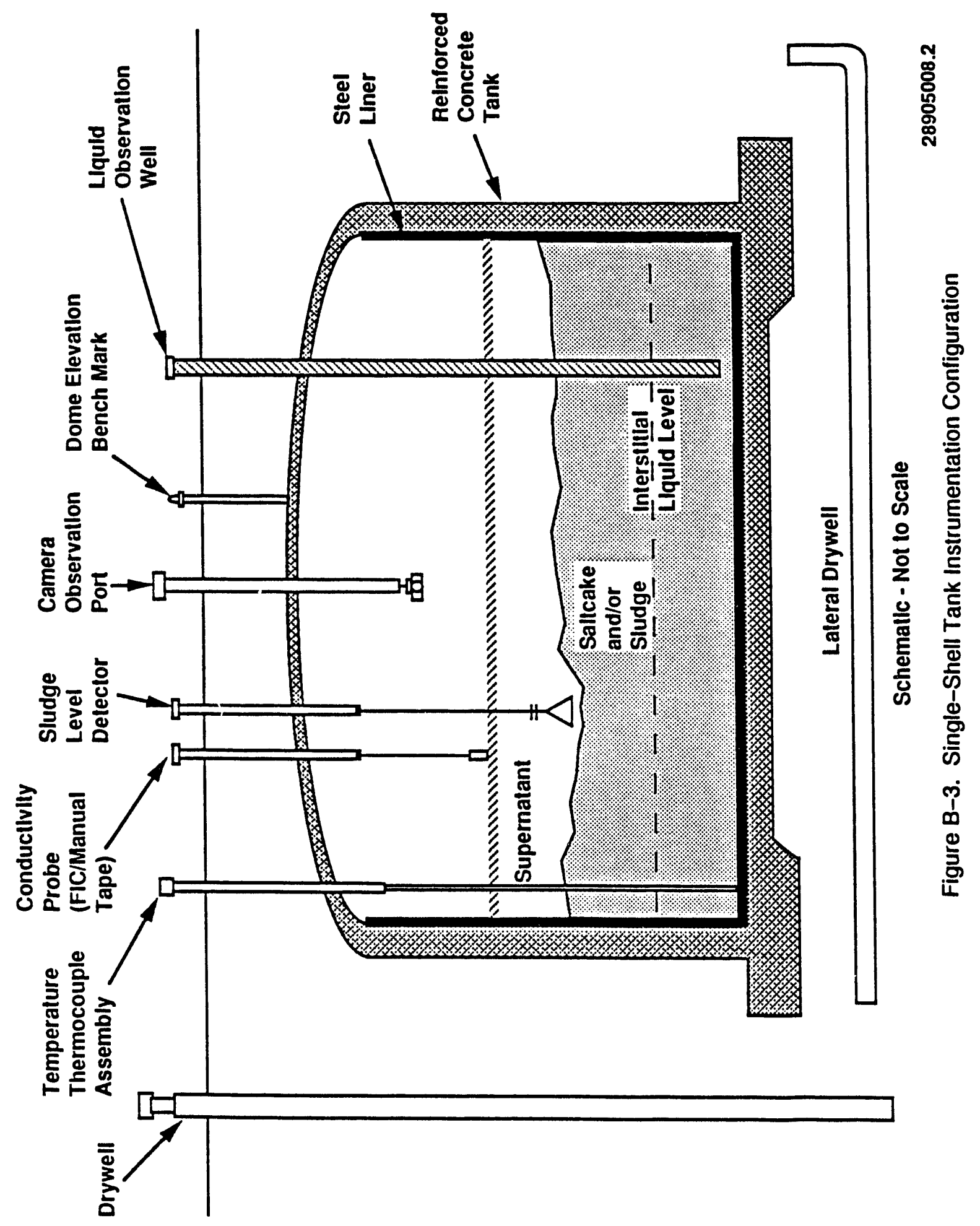


WHC-EP-0182-40

This page intentionally left blank.

B-6 
WHC-EP-0182

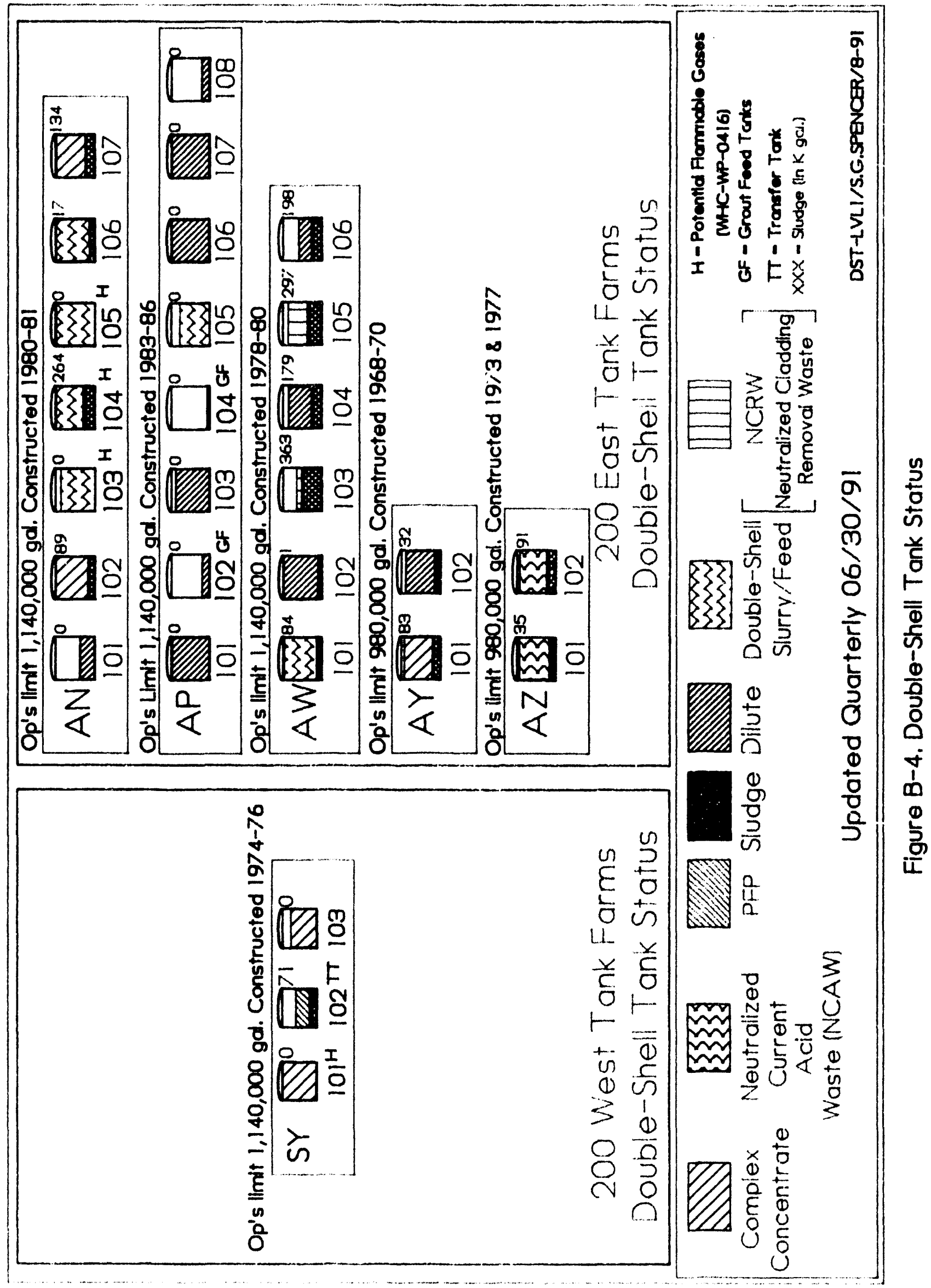

$B-7 / 8$ 
WHC-EP-0182

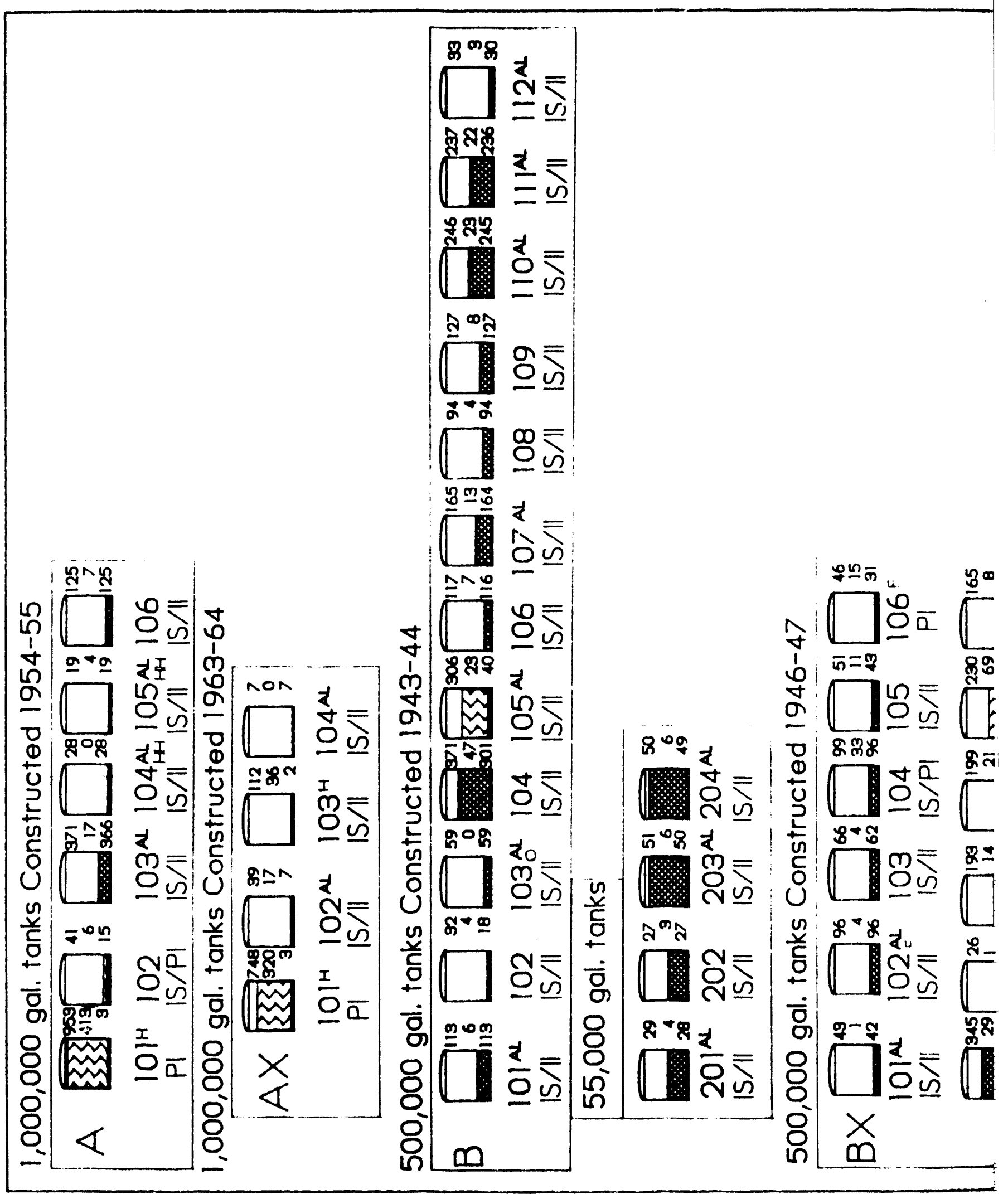




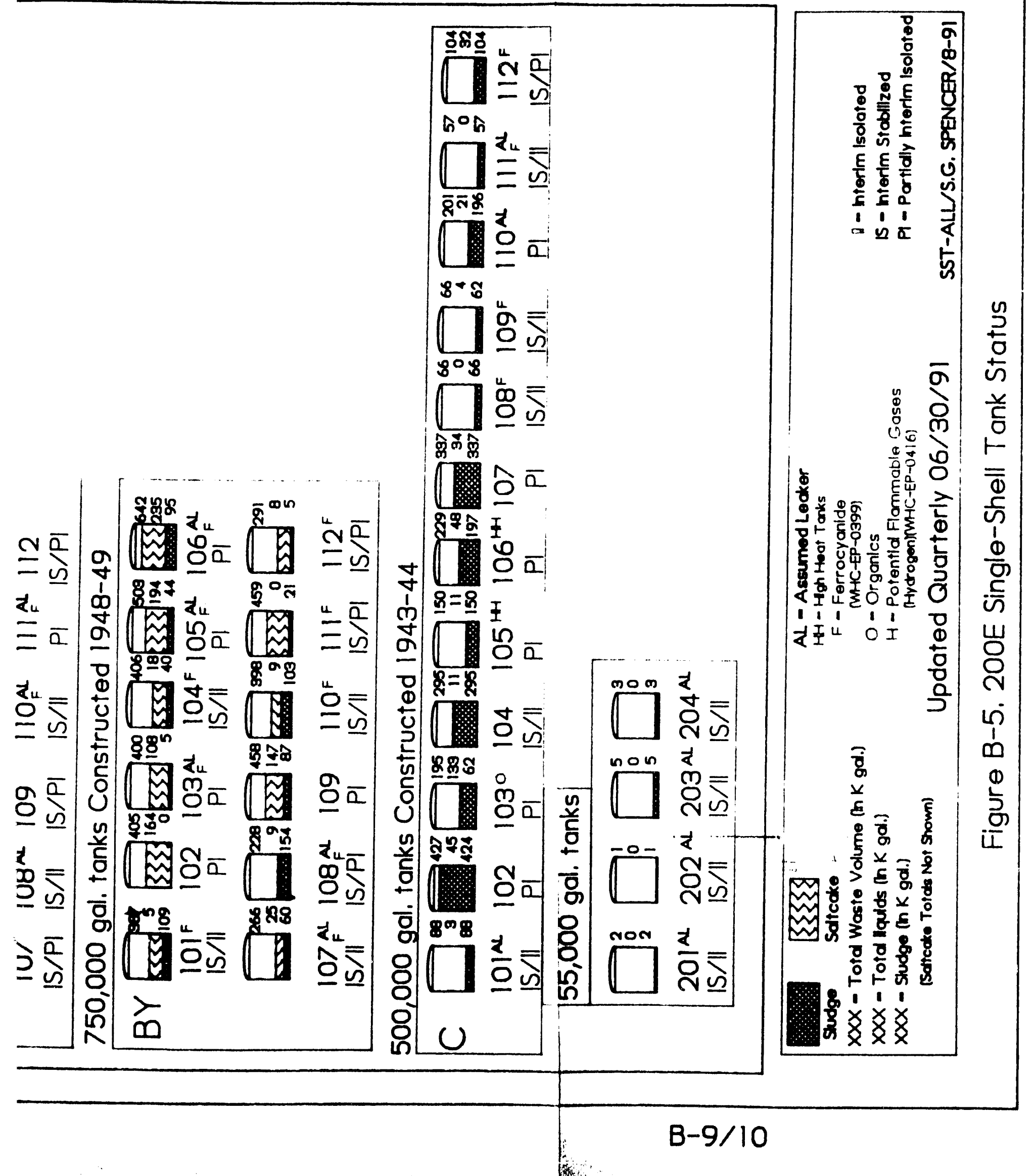


WHC-EP-0182

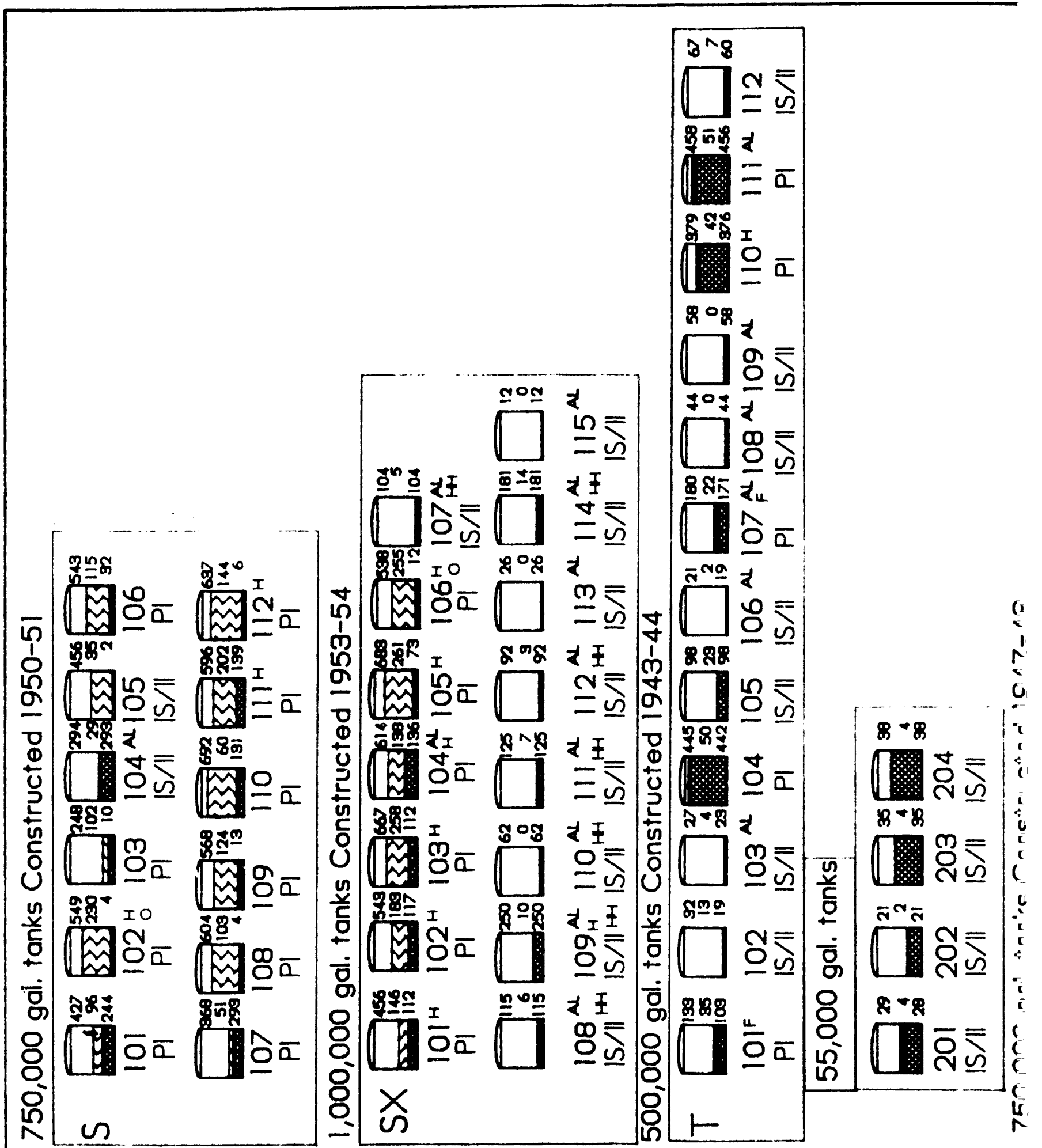




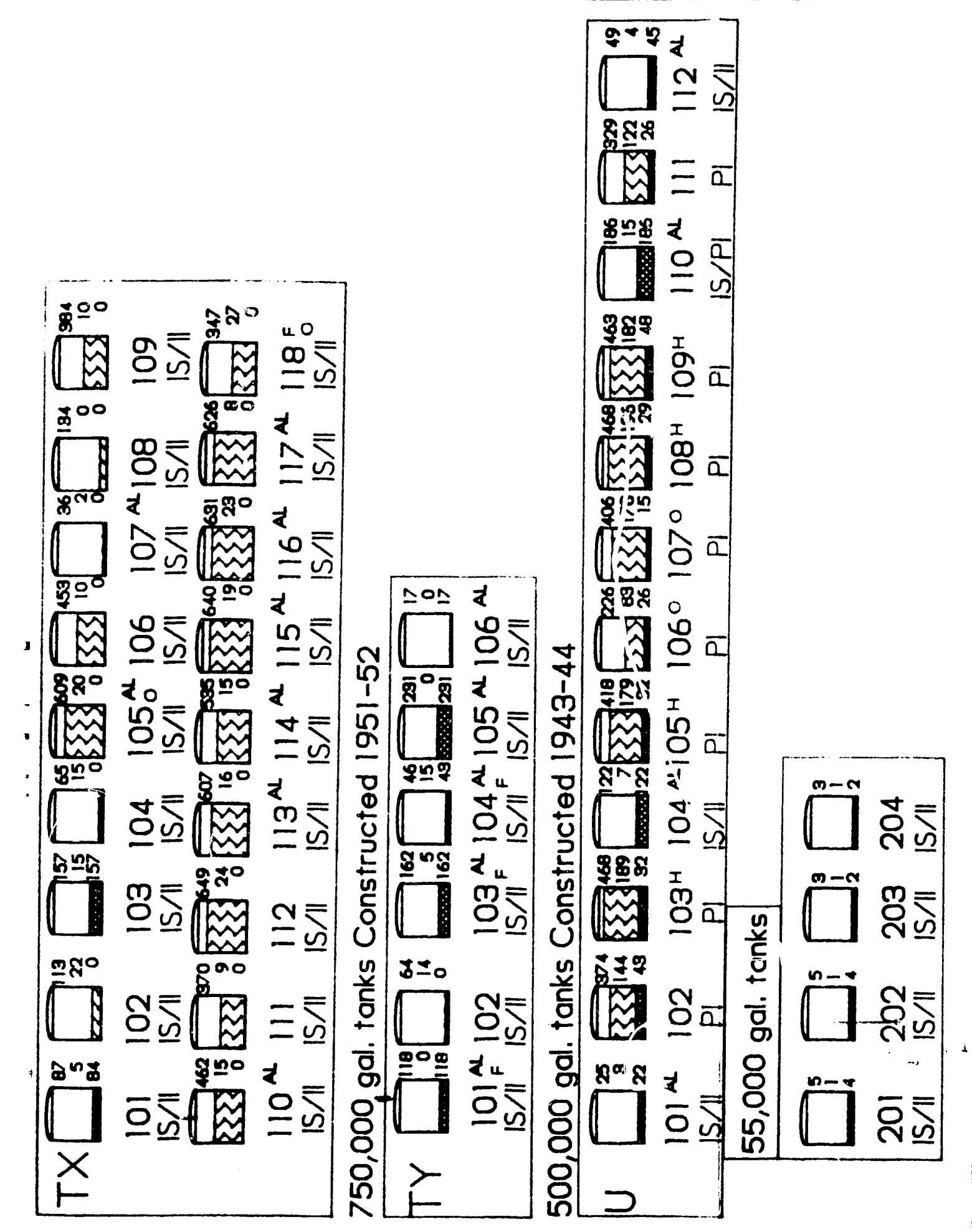




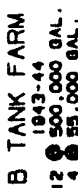

23:

28.

$\Rightarrow 20$

(2)

要求

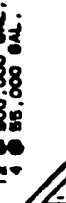

-

(1)
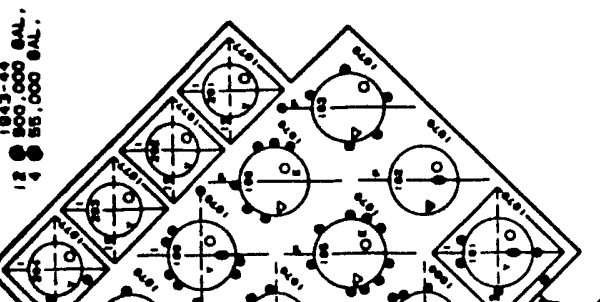

.
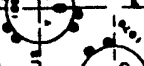

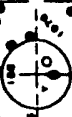

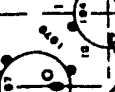

.

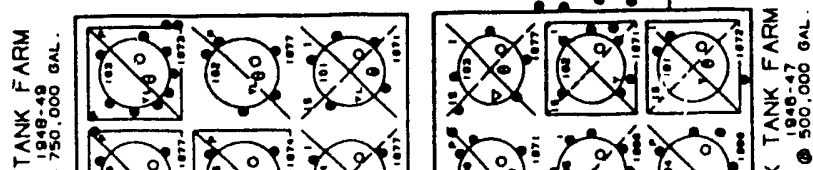

亩:

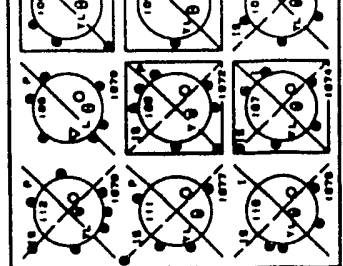

2.
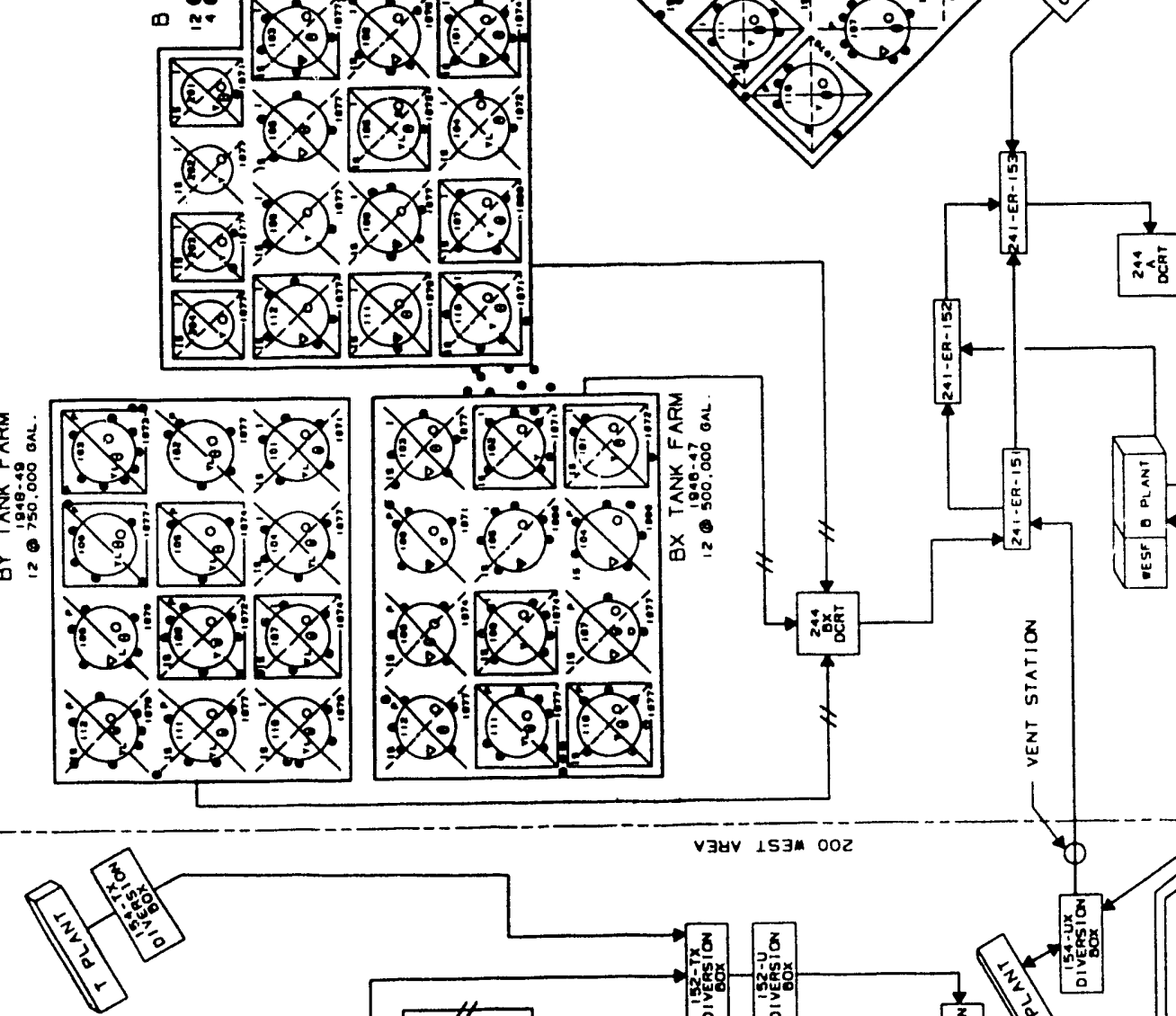

384 153m 002
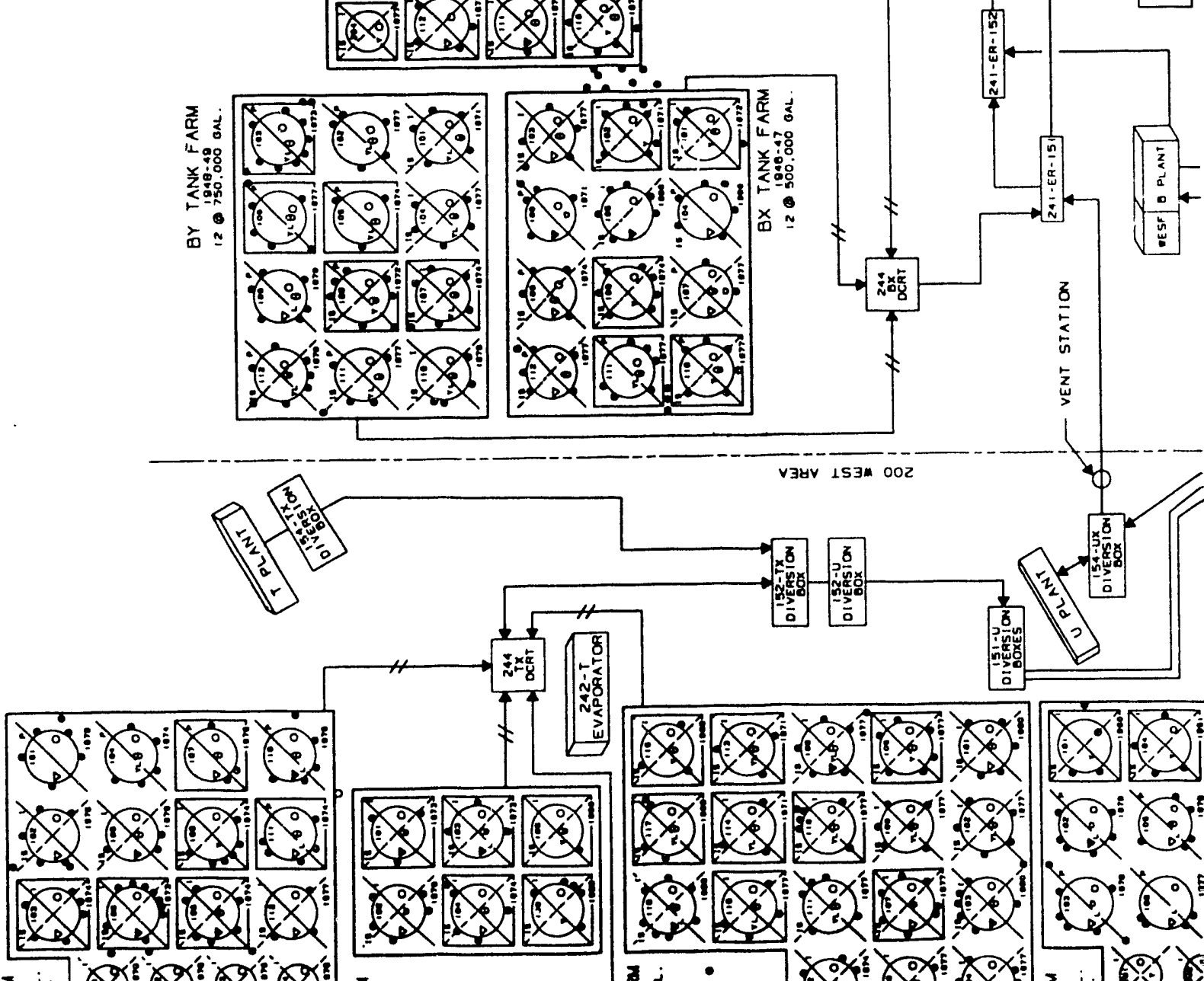

ख

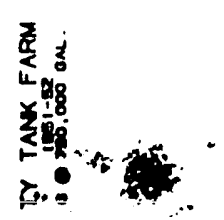

促

2) (6)

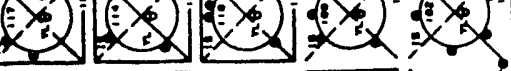
1

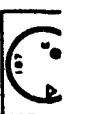




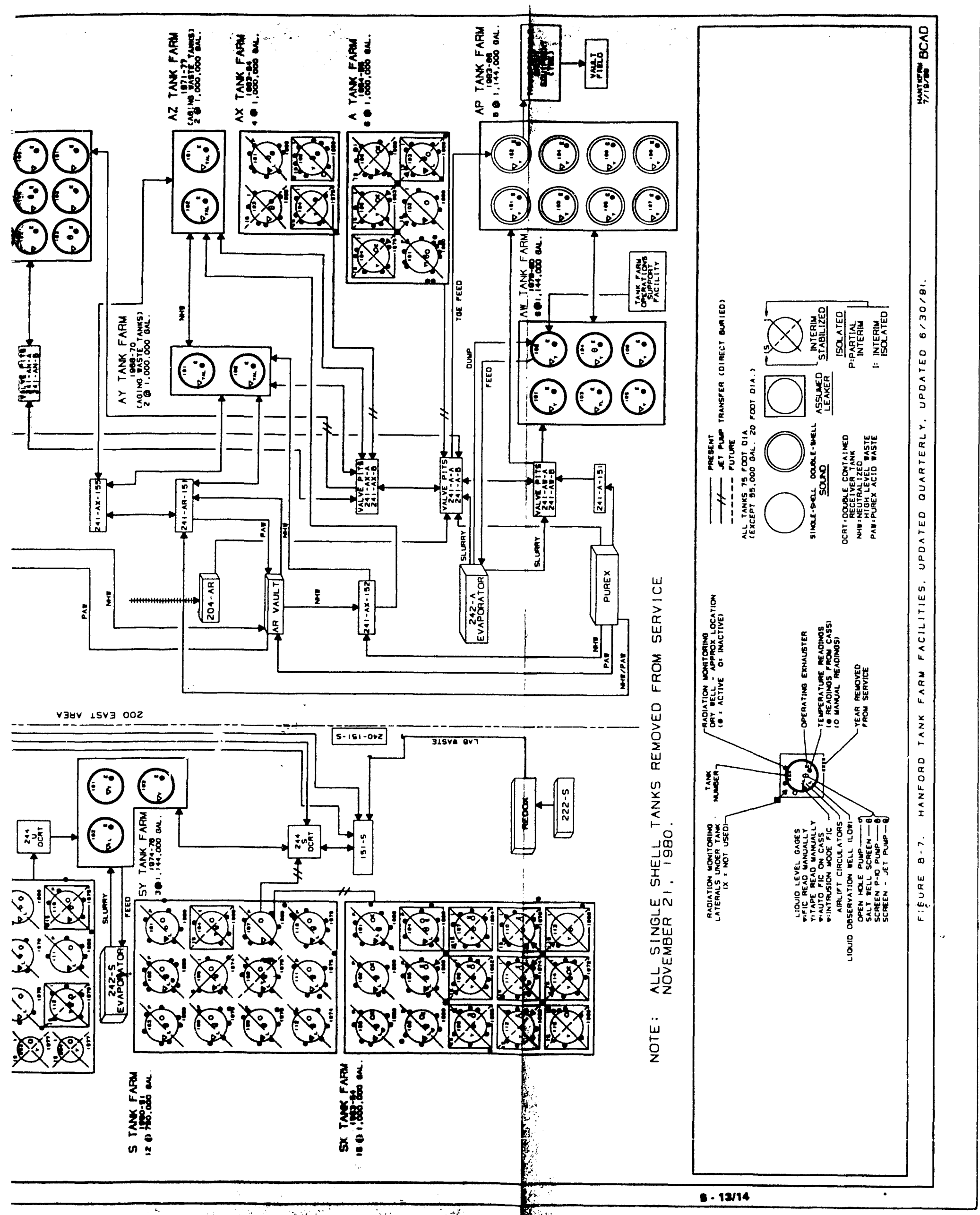


WHC-EP-0182-40

\section{APPENDIX C}

MONTHLY SUMMARY

TANK USE SUMMARY

INVENTORY SUMMARY BY TANK FARM

INVENTORY AND STATUS BY TANK 
WHC-EP-0182-40

This page intentionally left blank. 


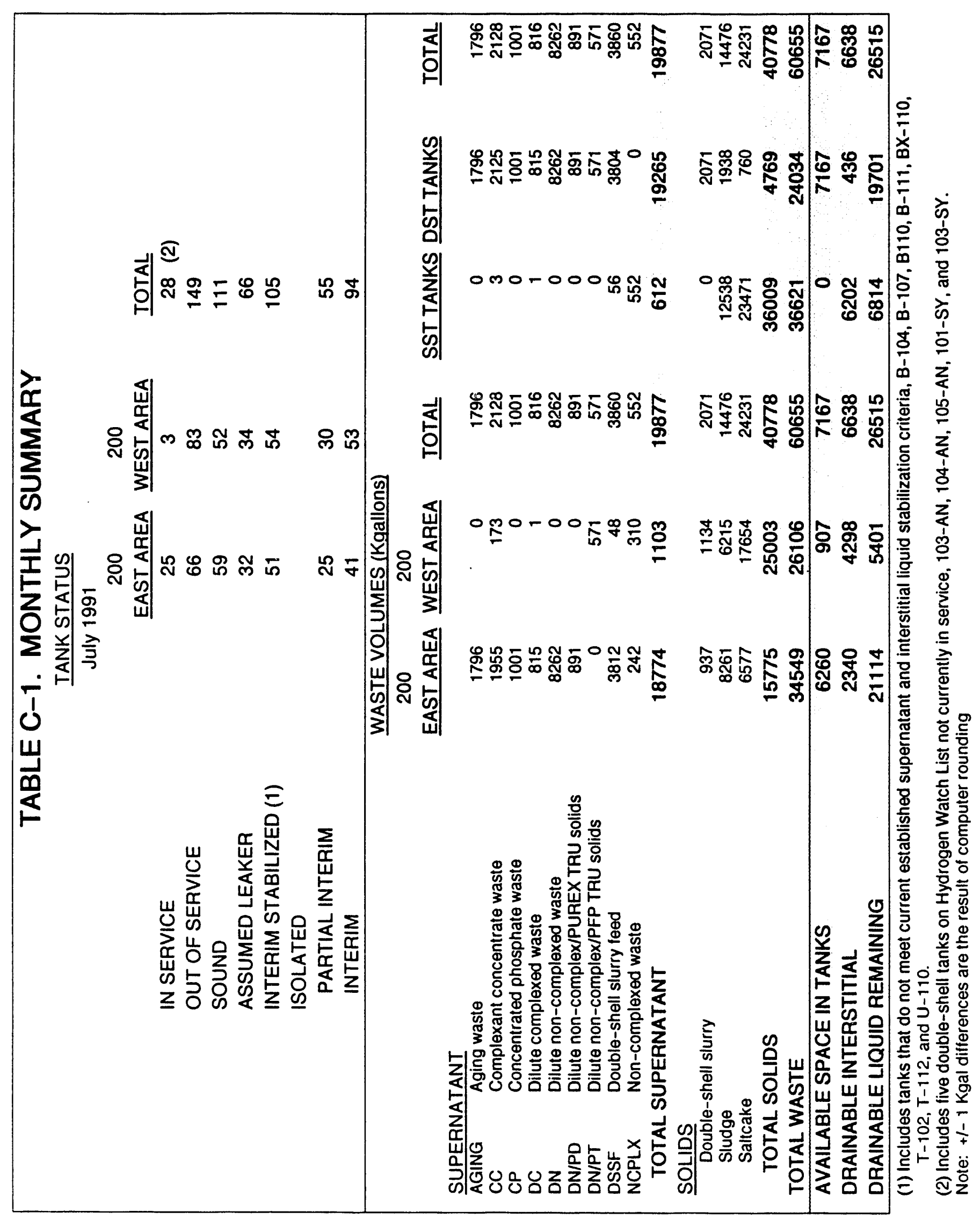




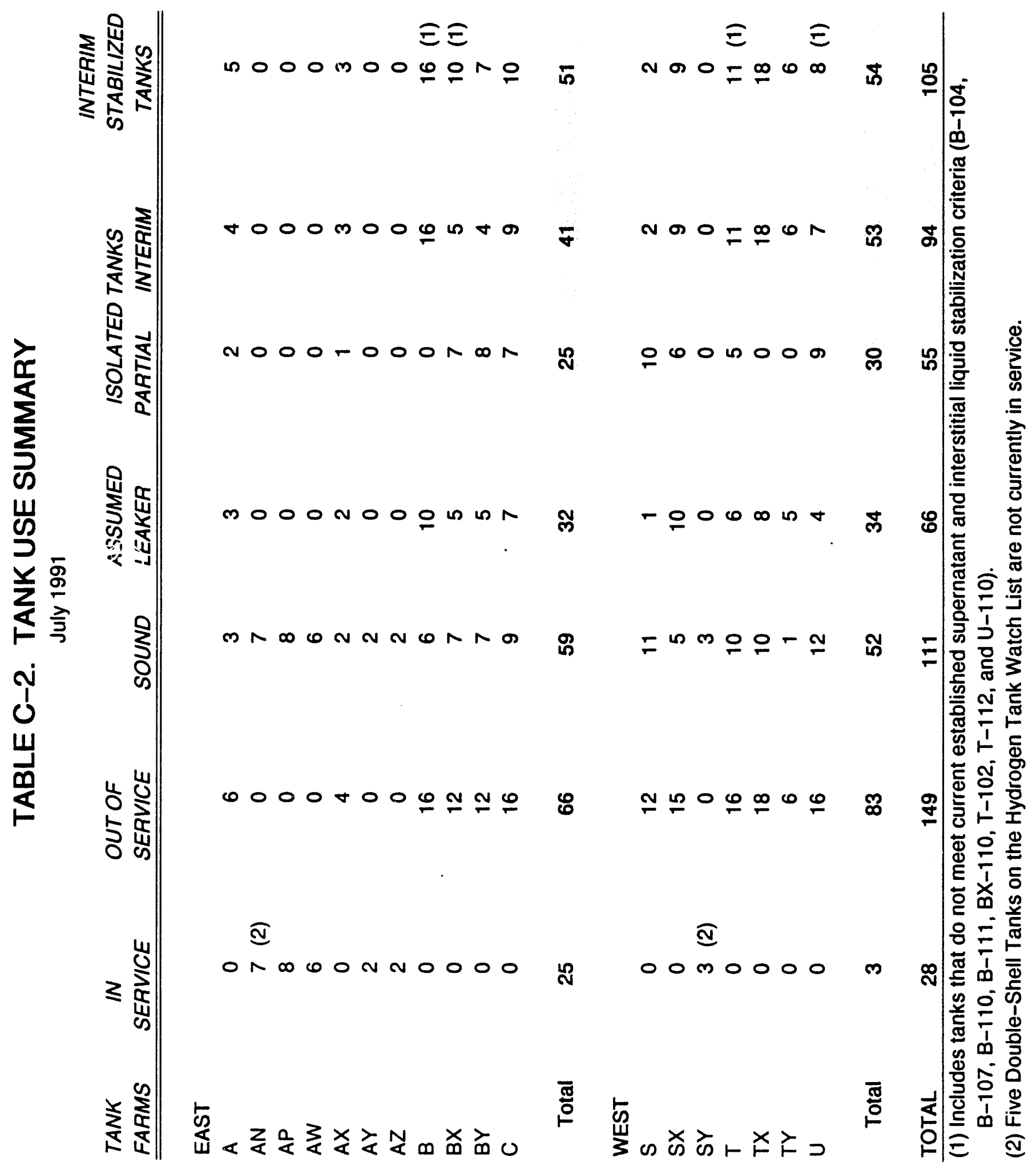




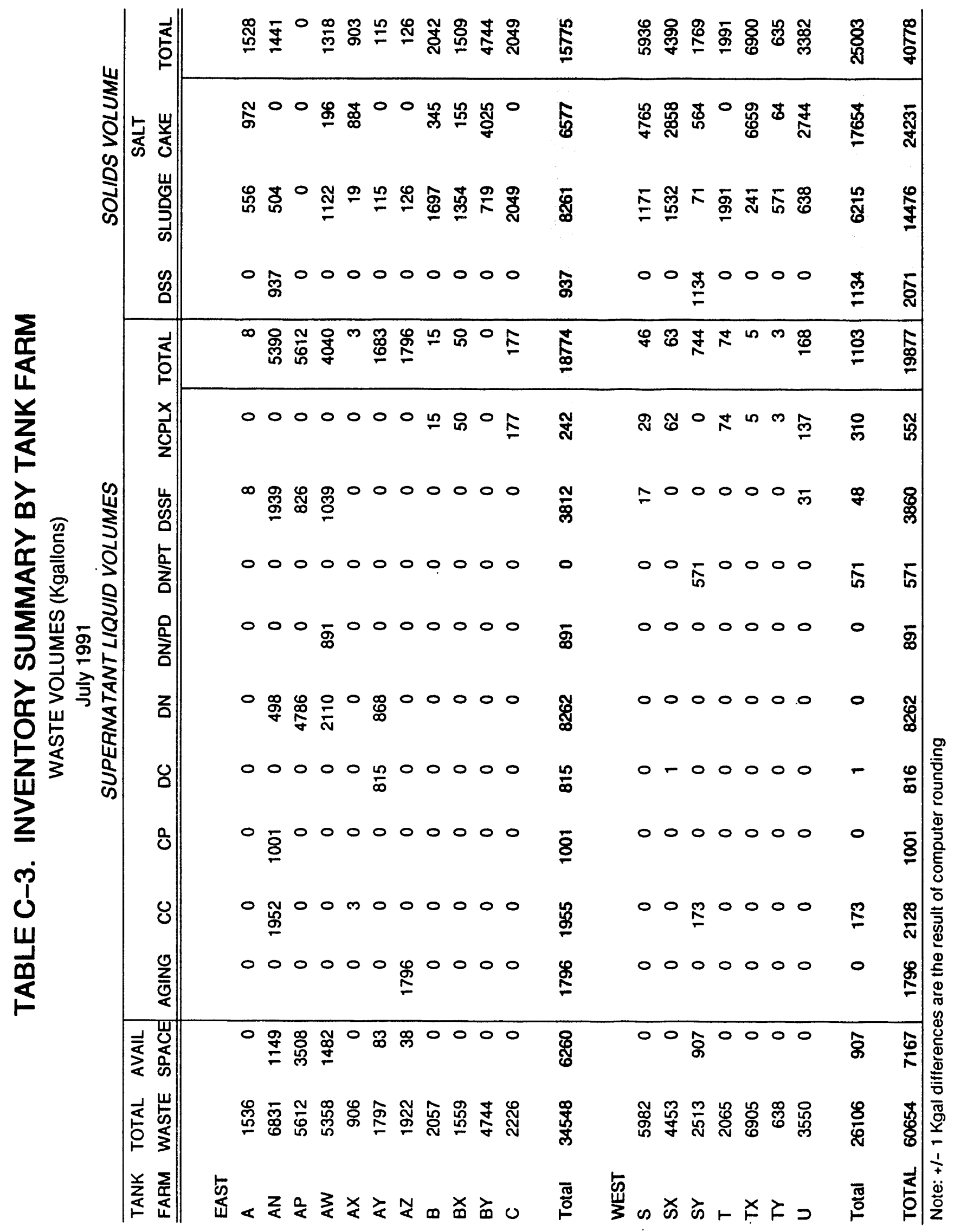


WHC-EP-0182-40

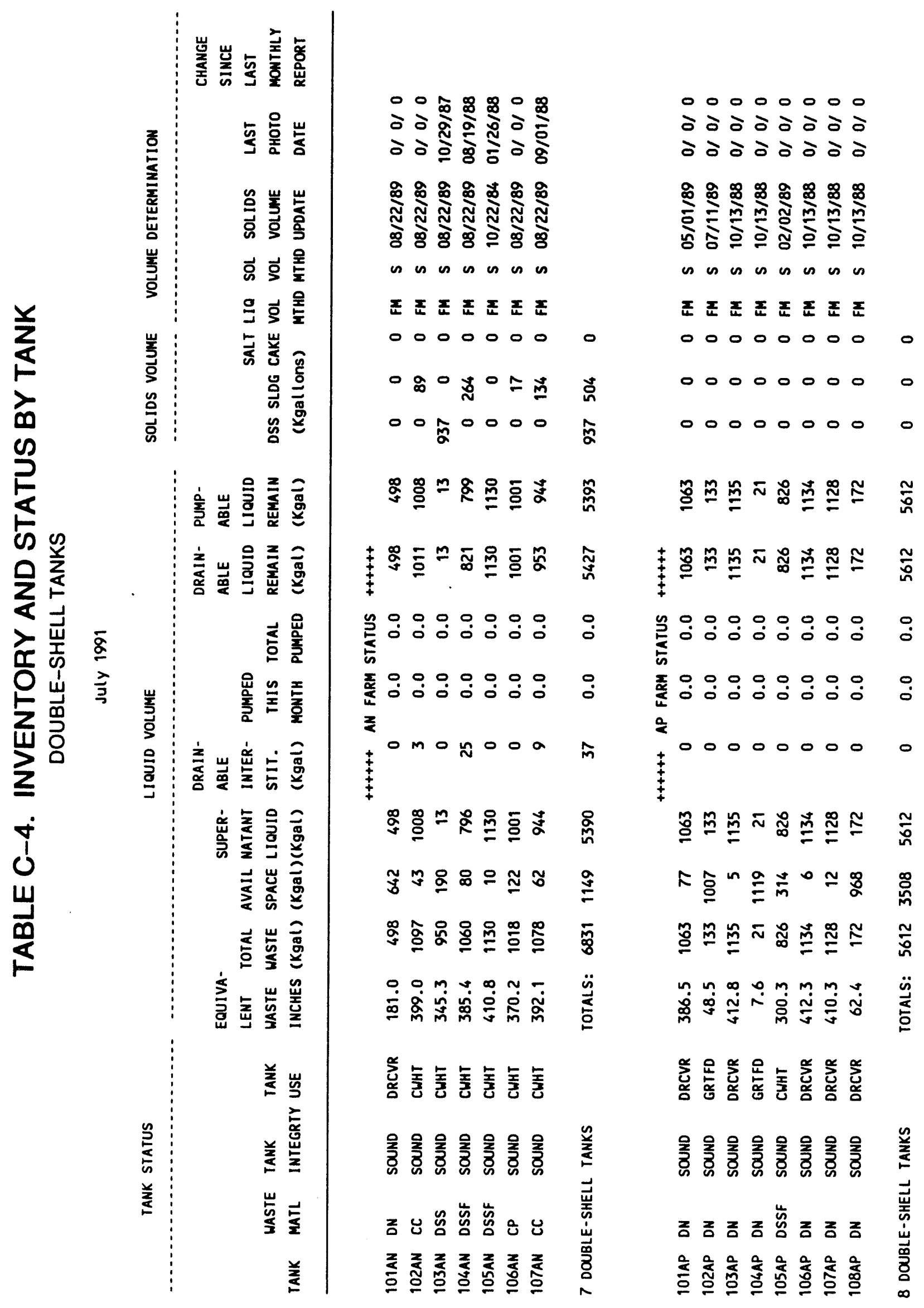


WHC-EP-0182-40

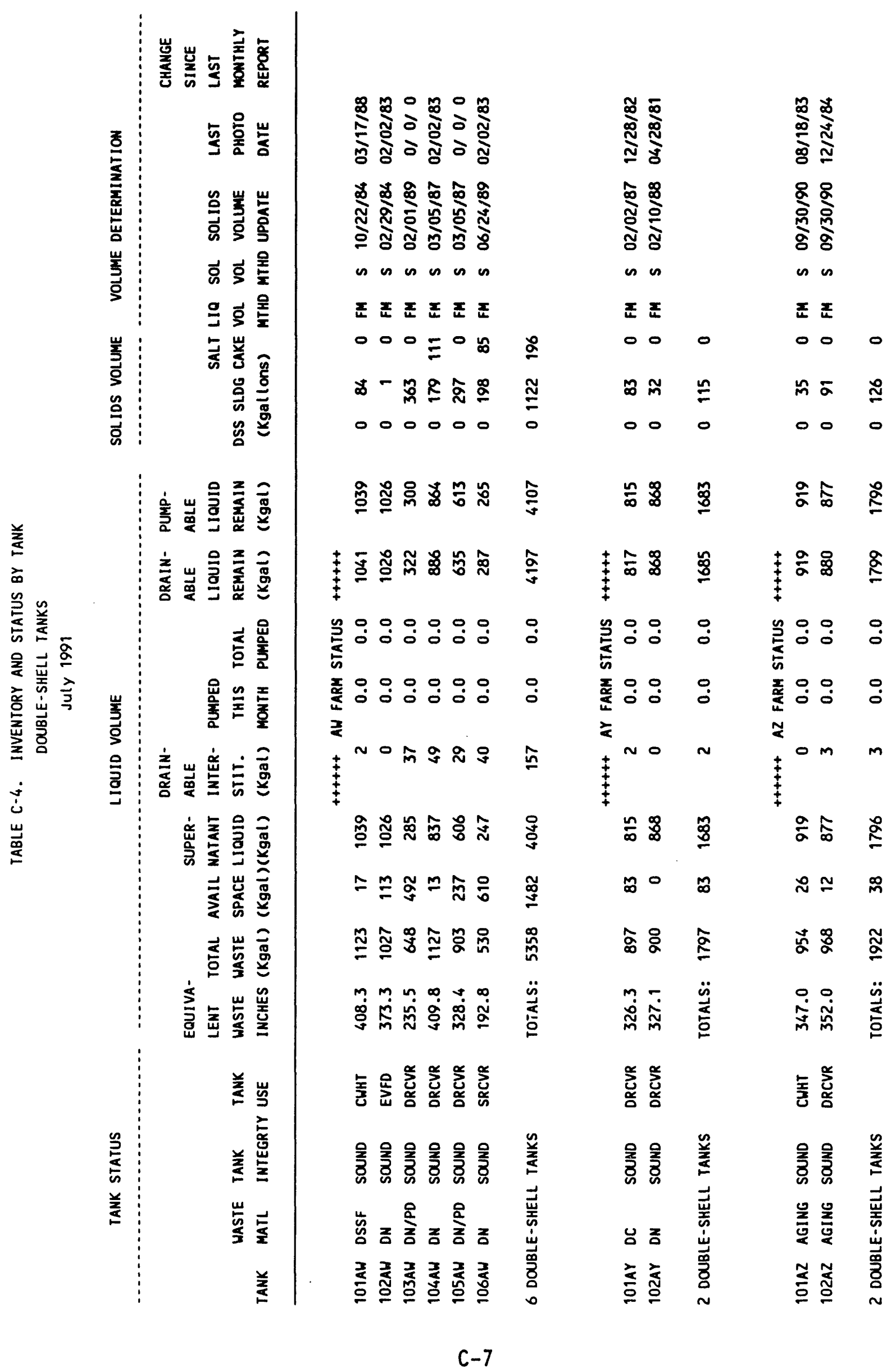


WHC-EP-0182-40

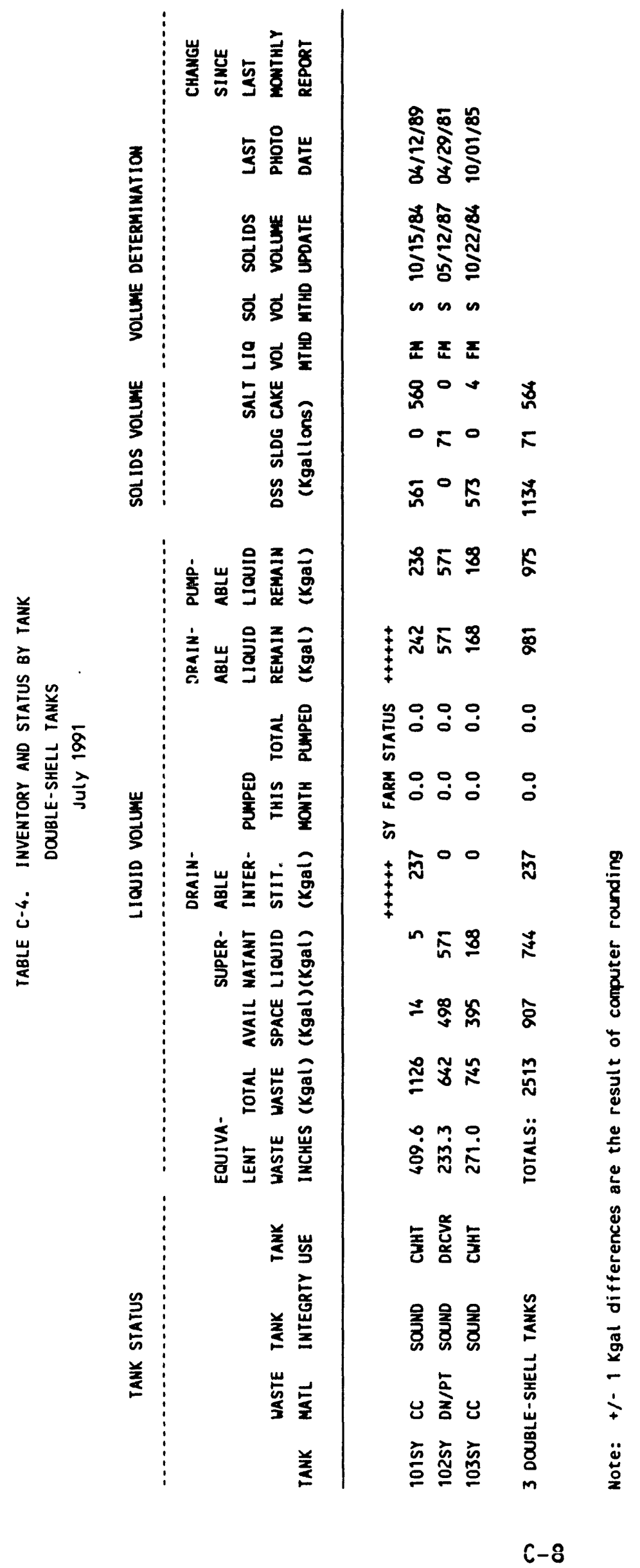




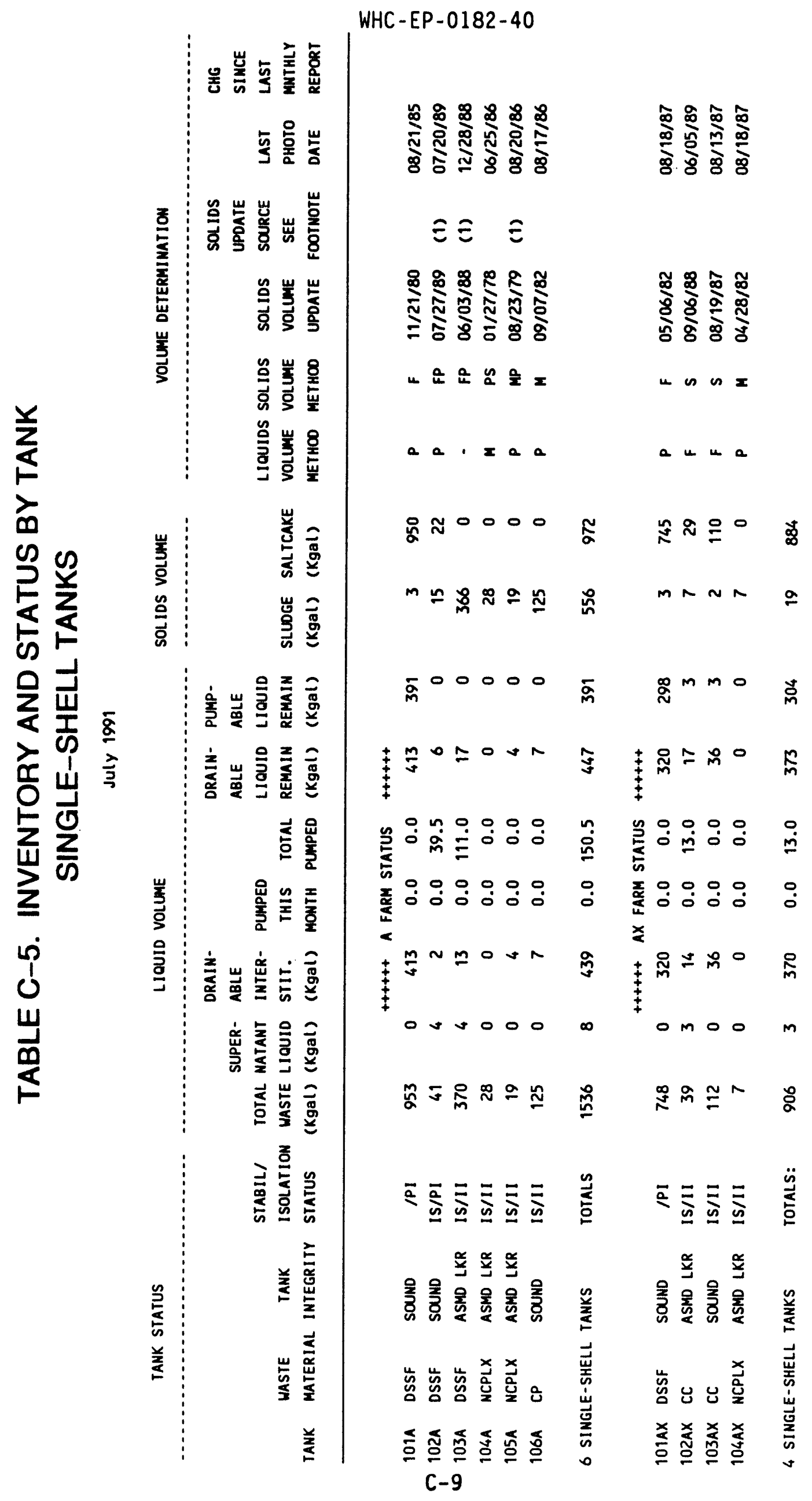




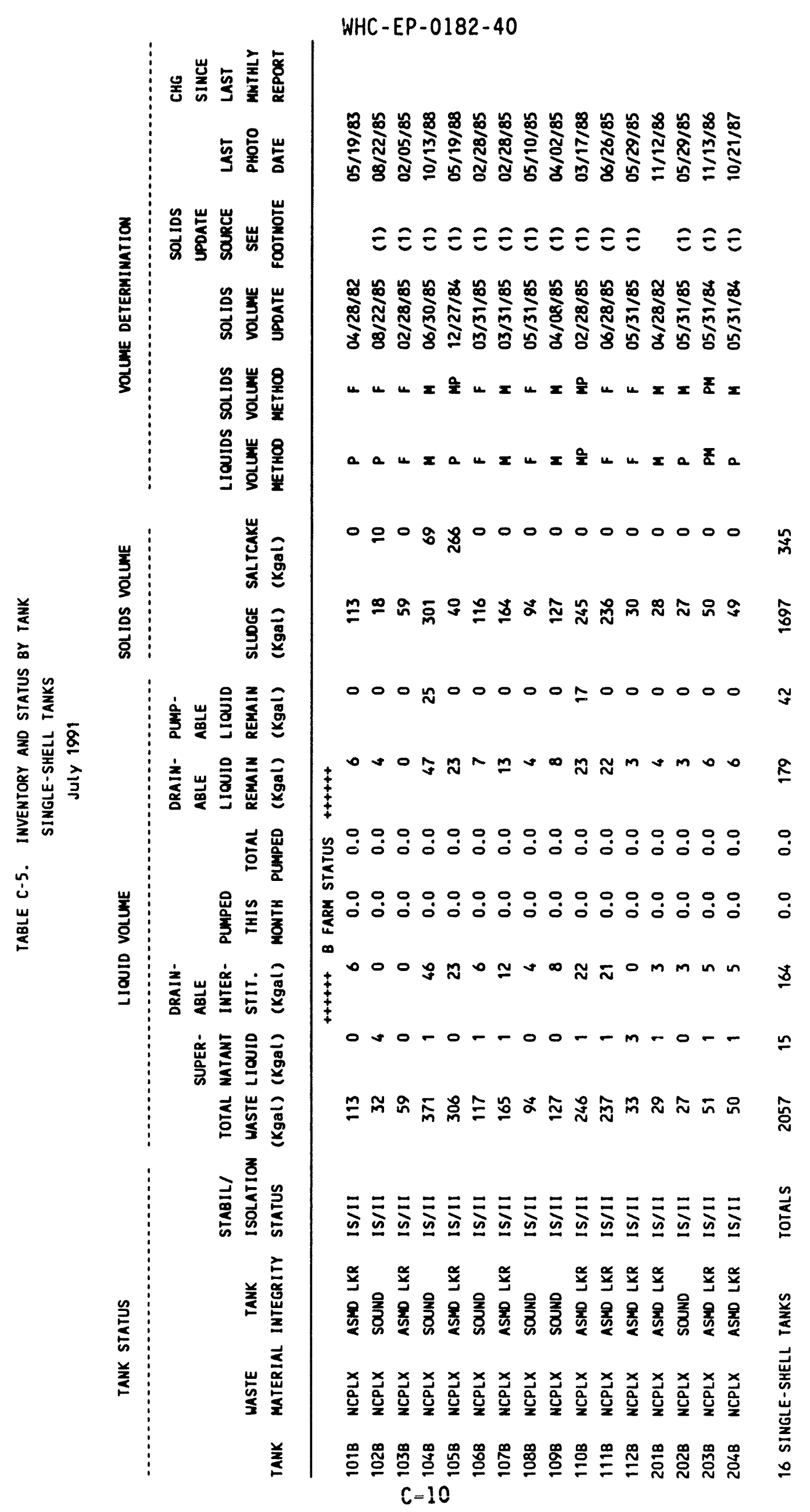


WHC - EP - 0182-40

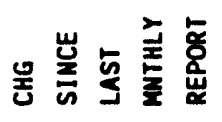

旁言呟

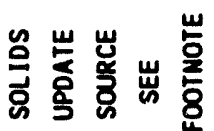

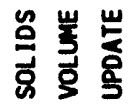

崖宸 宫宁产

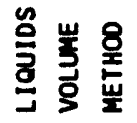

崖

美

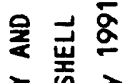

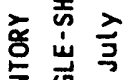

焉旁

悉

岕

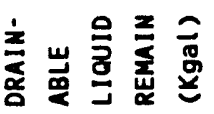

点 商

崖

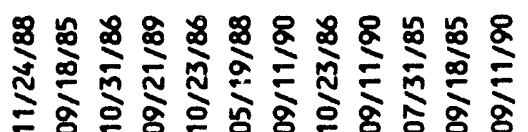

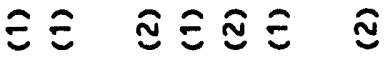

ณ ณ

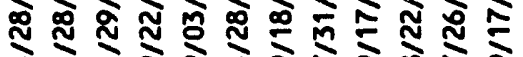

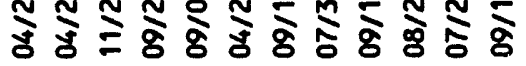

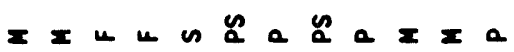

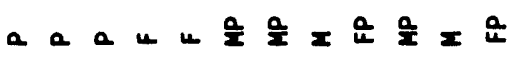

$0000 m 00000 \frac{2}{2}$

$\underline{n}$

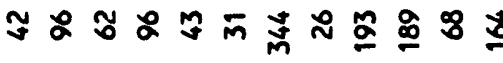

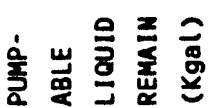

音

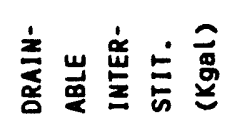

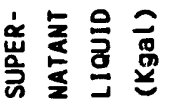

善

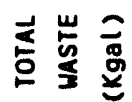

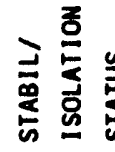

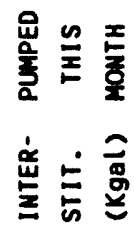

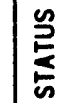

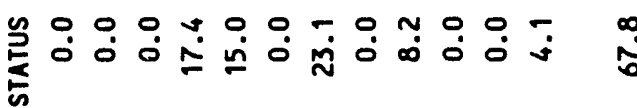

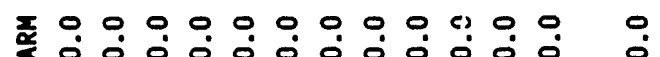

要

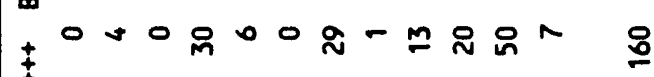

絜

$-0 \sin n=00-a-0$

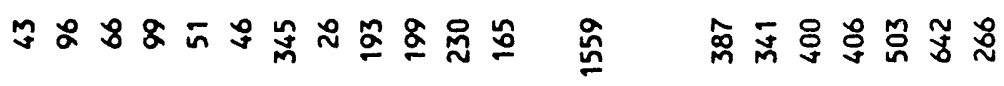

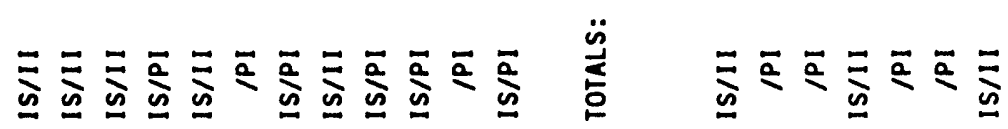

美尊 $\cong$

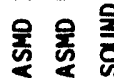

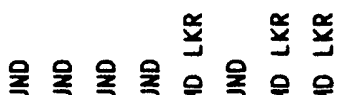

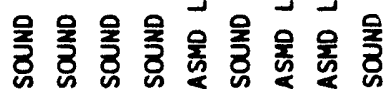

崖敦

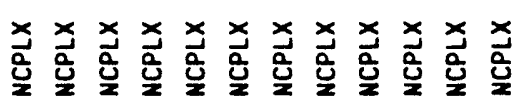

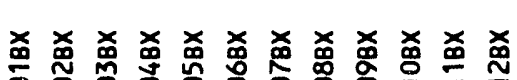

盖

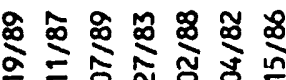

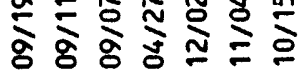

ฐิ ฐ

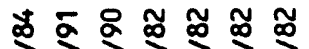

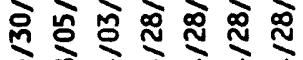

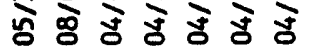

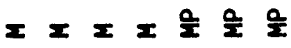

a 울 울 a a a a

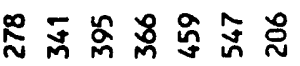

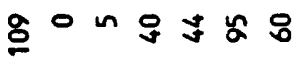

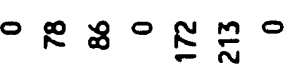

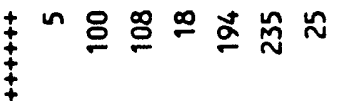

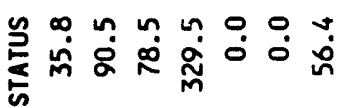

준연

商

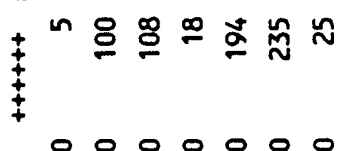

0000000

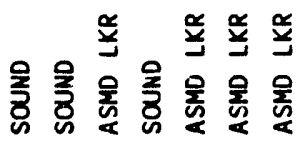

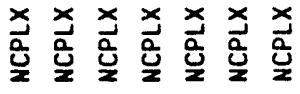

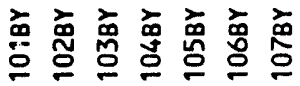




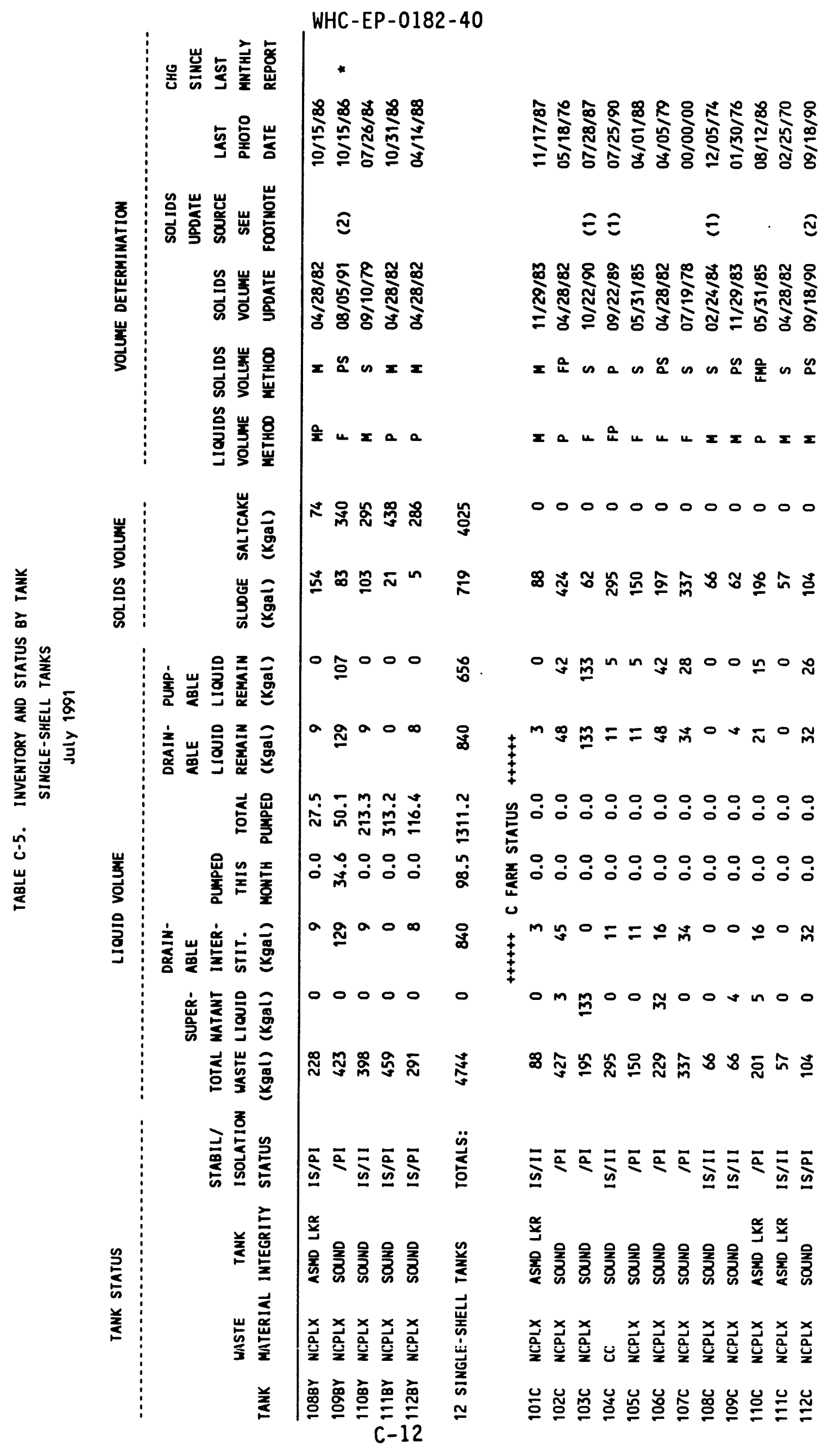




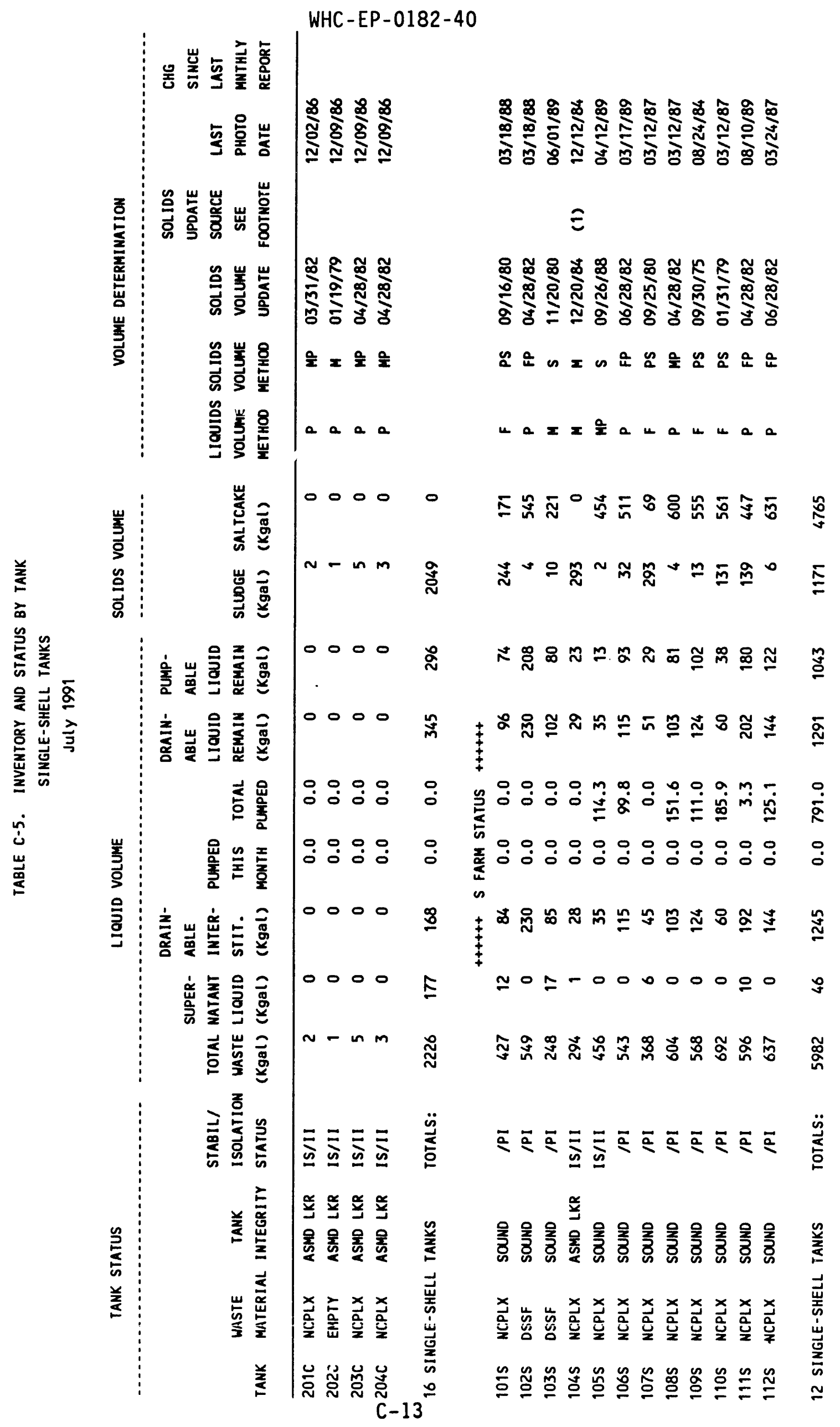




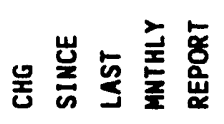

旁害宸

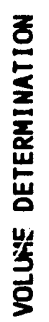

盖兽

旁旁

是焉㐫

咅岕言

$\sum^{2}$

نُ

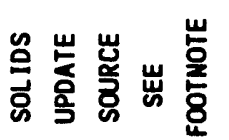

苨崖容

올 울

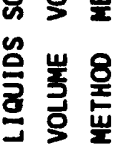

崖

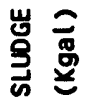

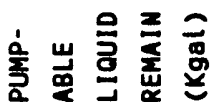

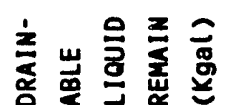

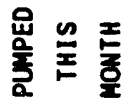

WHC - EP- $0182-40$

జ

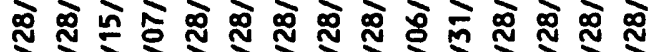

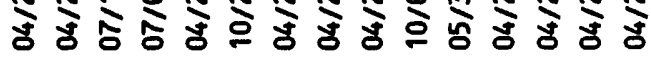

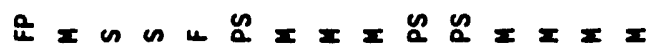

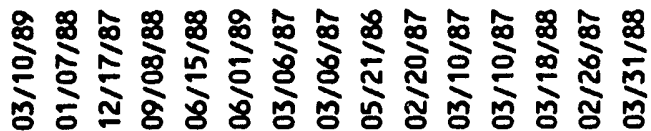

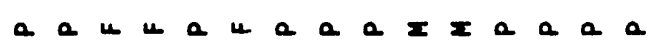

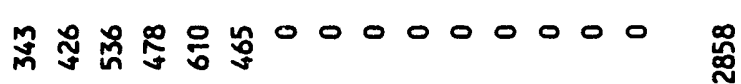

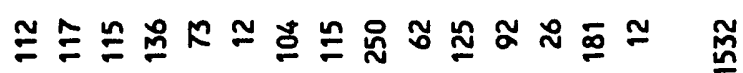

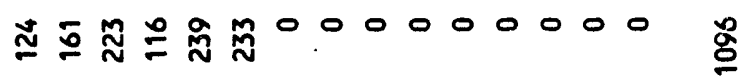

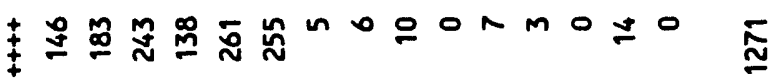

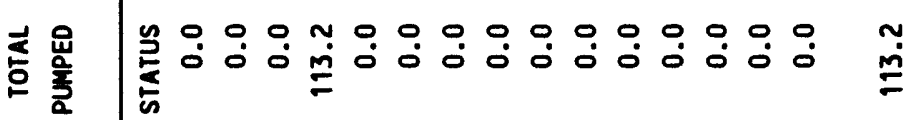

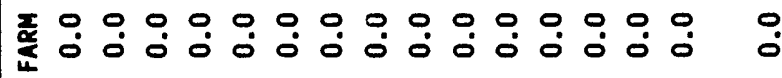
x

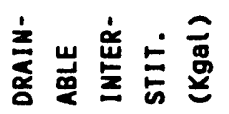

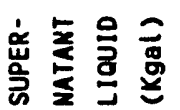

吉崖喜

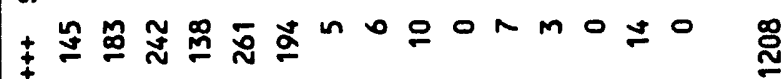
$+$

要总总总

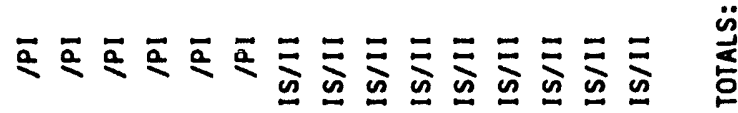

美

美总

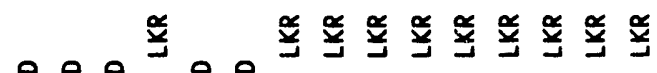

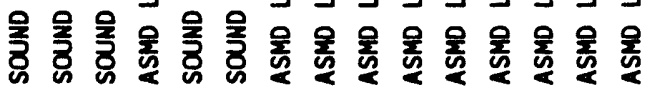

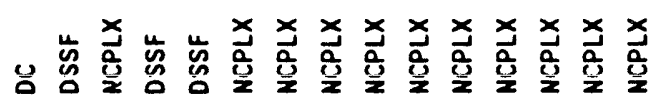

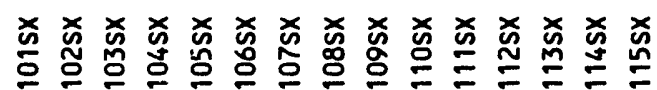

C-14 


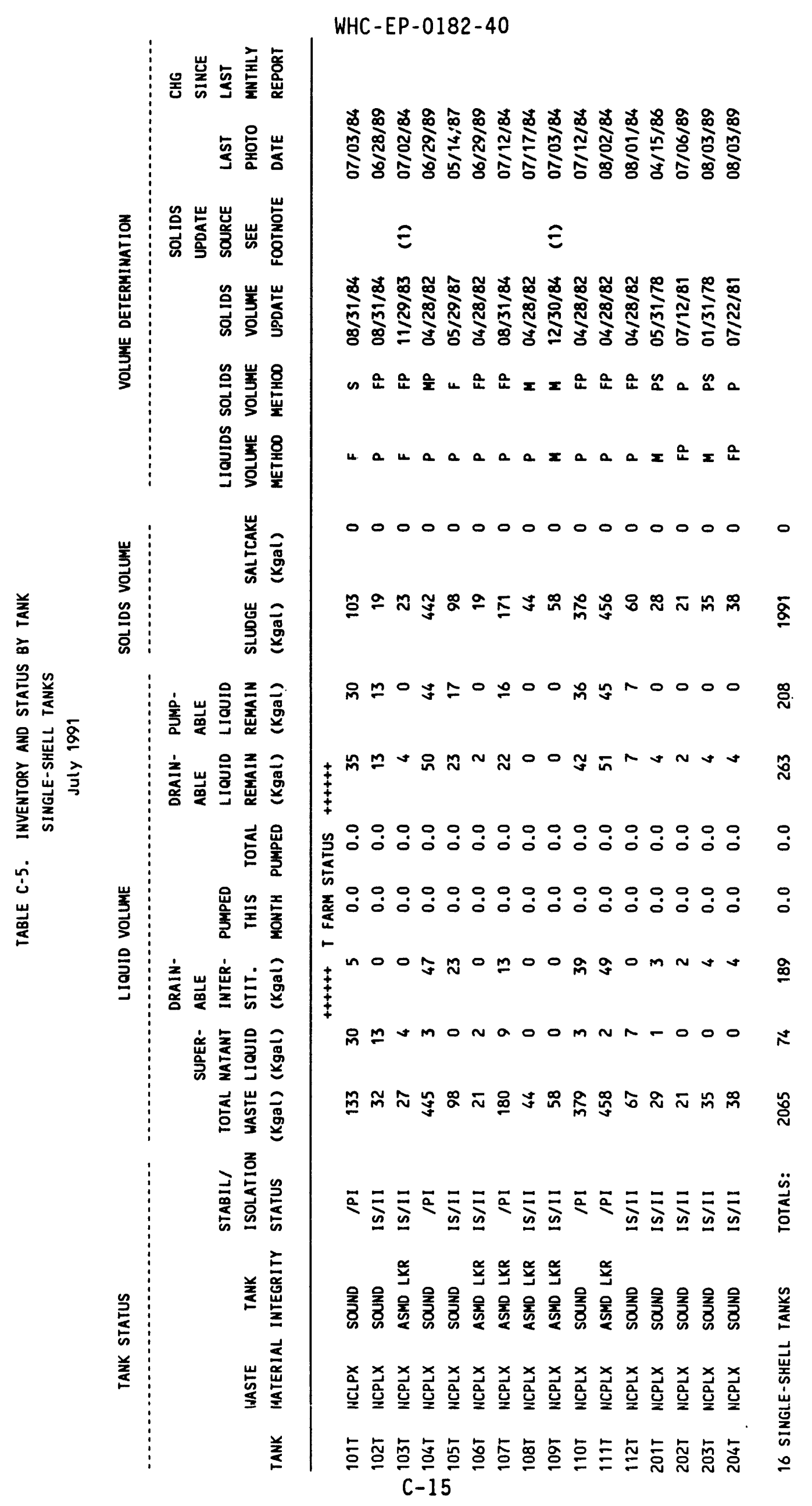




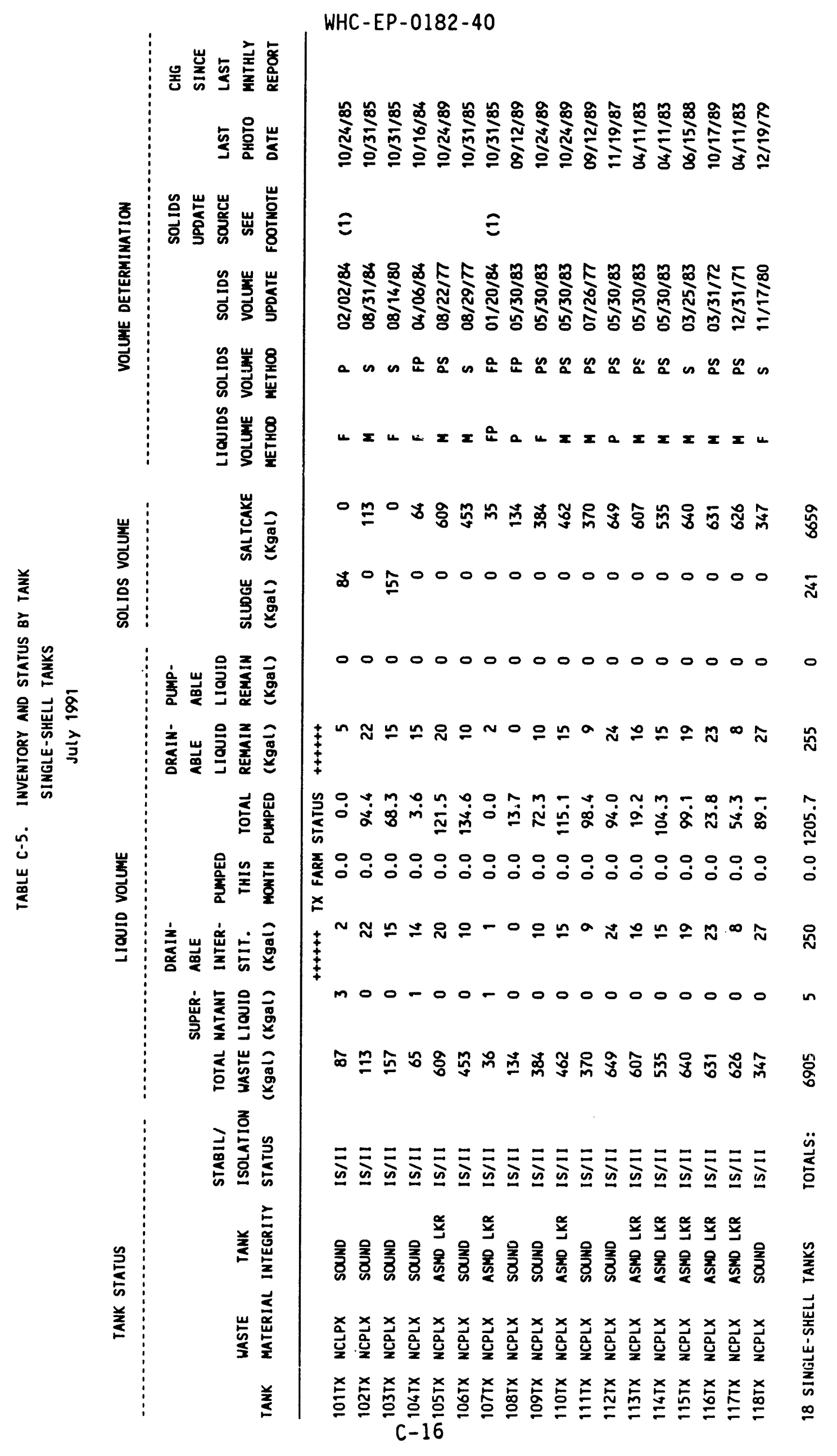




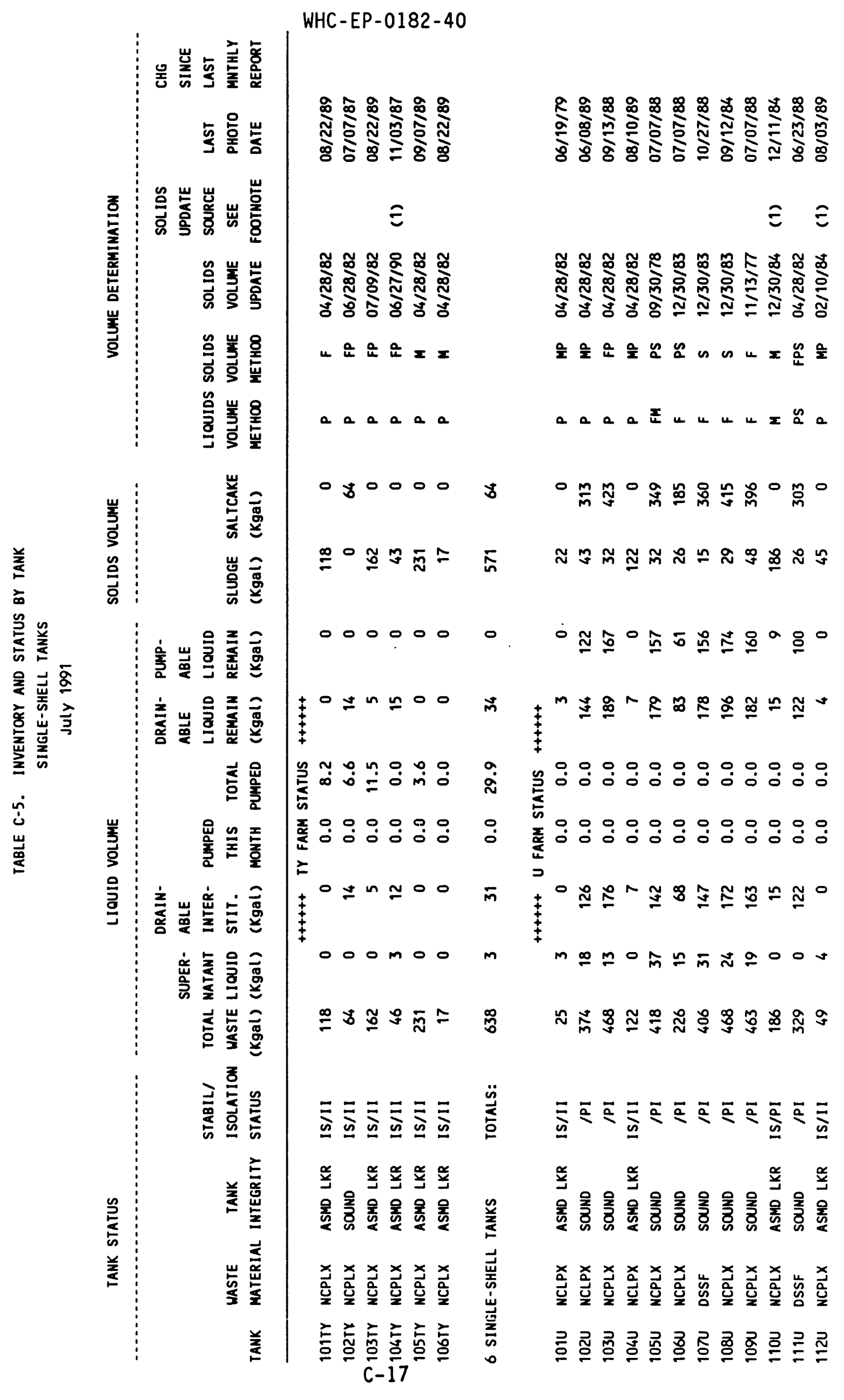




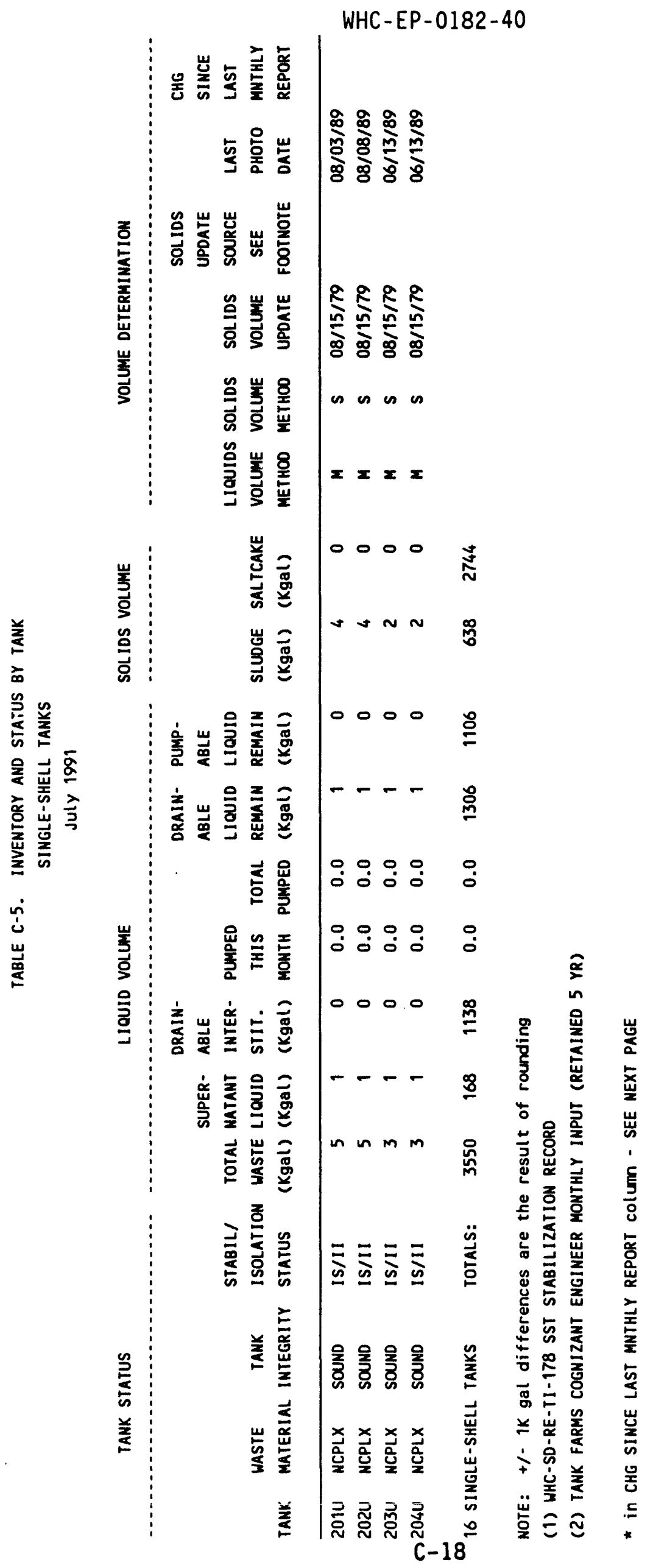




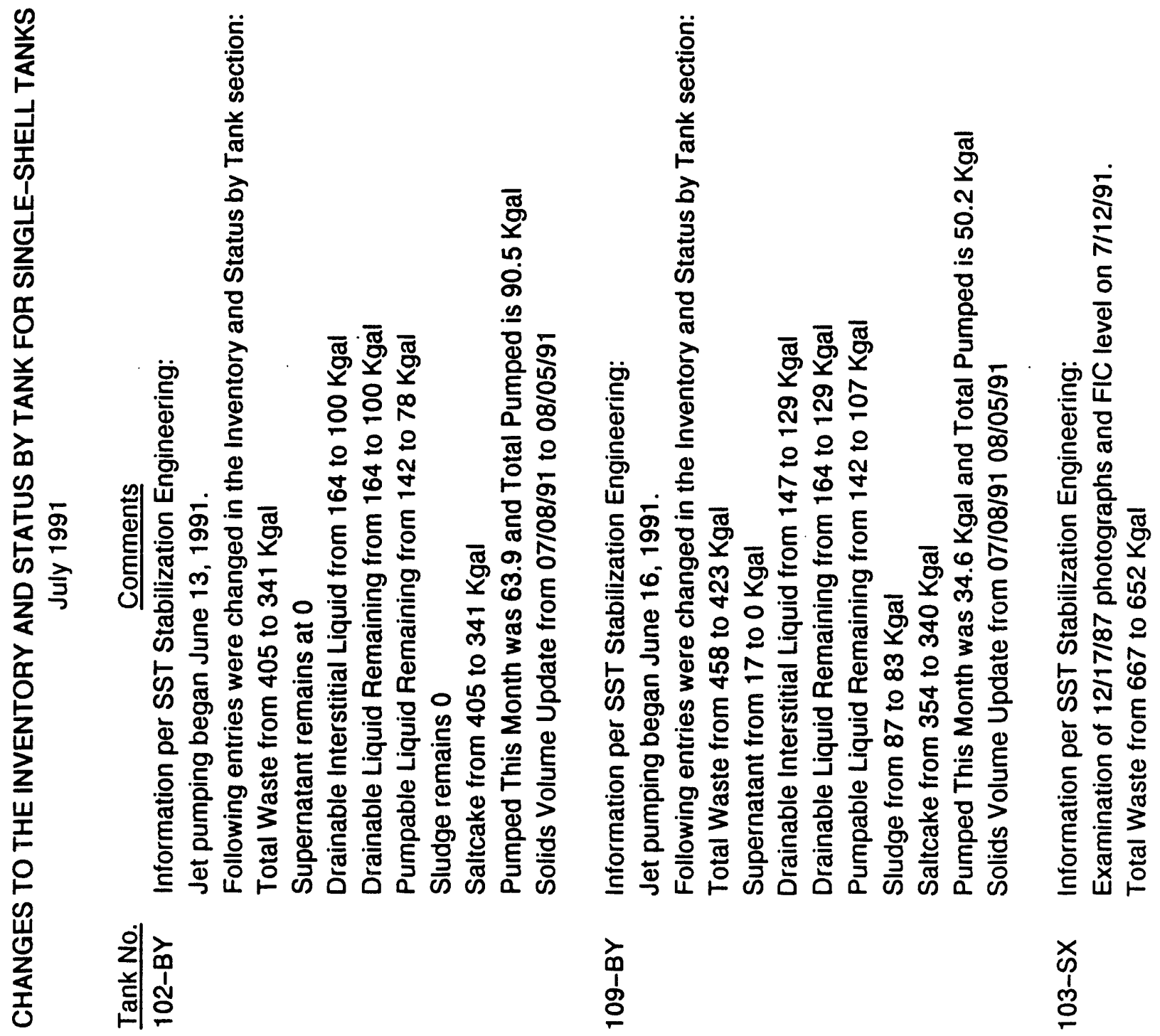


WHC-EP- $0182-40$

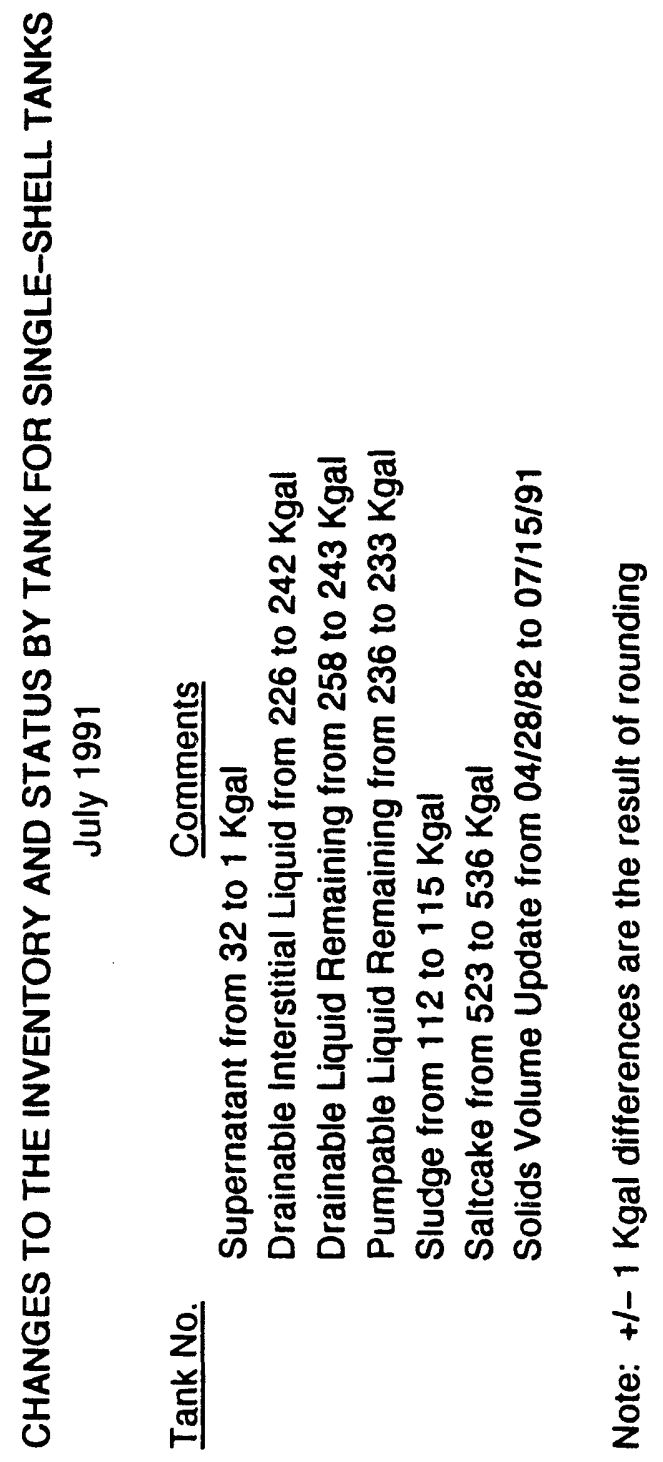


WHC-EP-0182-40

APPENDIX D

PERFORMANCE SUMMARY

D-1 
WHC-EP-0182-40

This page intentionally left blank.

D-2 


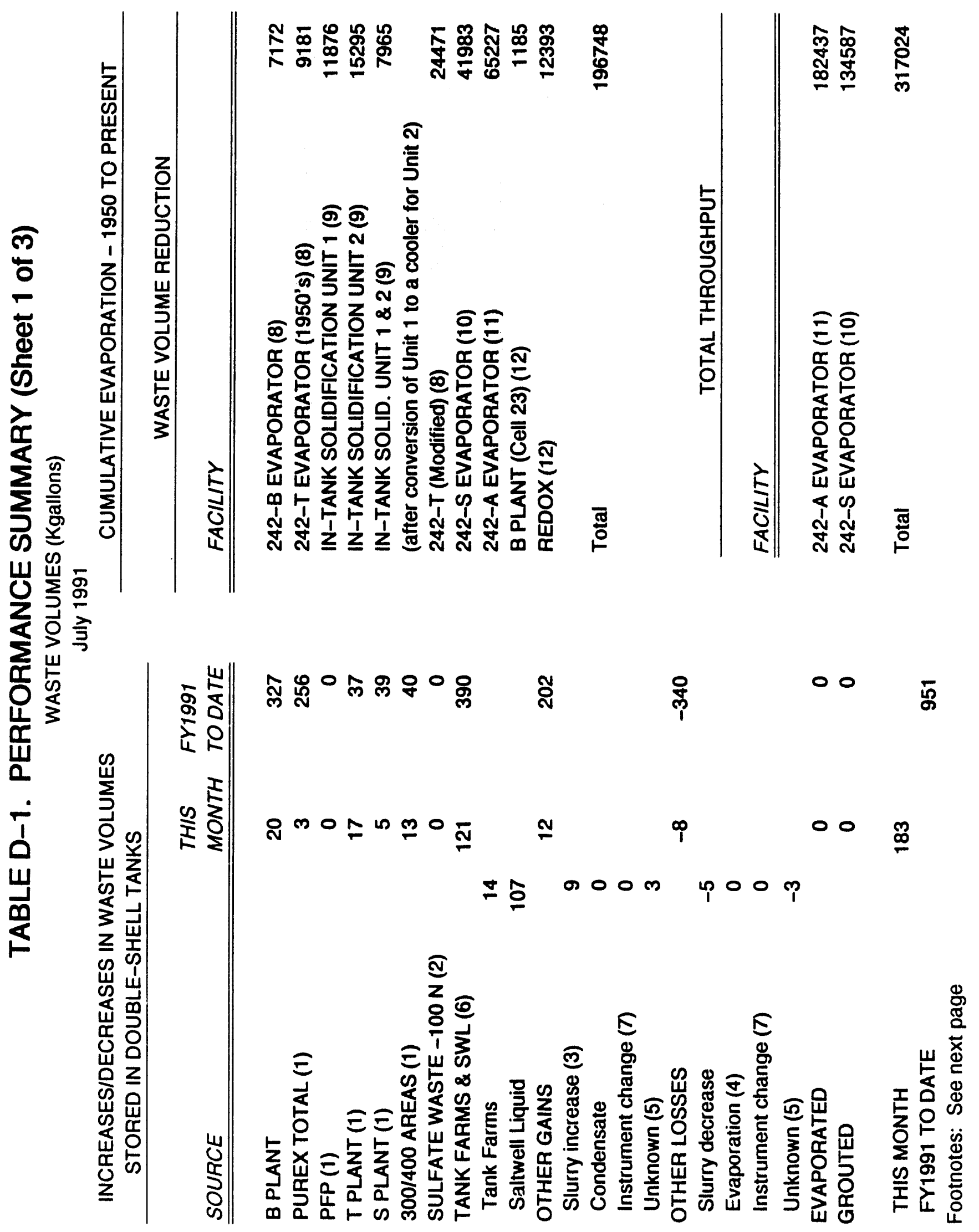


TABLE D-1. Performance Summary. (sheet 2 of 3 )

Footnotes:

\section{INCREASES/DECREASES IN WASTE VOLUMES}

(1) Including Flush

(2) Sulfate waste is generated from ion exchange backflushing and sand filter clean out, resulting in sulfate waste $\left(\mathrm{Na}_{2} \mathrm{SO}_{4}\right)$.

(3) Slurry increase/growth is caused by gas generation within the waste. The gas which is trapped in the waste expands the waste in the tank causing the surface level and volume to increase.

(4) Aging waste tanks

(5) Unknown waste gains or losses may be due to rounding calculations, clean water slowly leaking through a valve, changes in levels due to ambient temperature changes, different measuring devices being used by Tank Farm operators, transfers taking place during the end of the month, Tank Farm activities such as miscellaneous water additions not associated with facility waste generation, or the addition of water which is added to aging waste tanks and then evaporated off.

(6) Tank Farms miscellaneous flushes.

(7) Liquid level measurement instrument changes from the automatic FIC to manual tape (and vice versa) result in unusual gains or losses because the manual tape may rest on an uneven crust surface giving a different reading from that of the automatic F.C. These instrument changes are made when the automatic FIC is out of service and the reading from the manual tape is used for reporting purposes. The reported reading reverts back to the automatic FIC when it is repaired.

\section{WASTE VOLUME REDUCTION}

(8) Currently inoperative. These evaporator systems (242-B and 242-T) were installed in 1952 in each of the two operating areas to remove water from the waste, and ran for approximately $4 \mathrm{yr}$ after which both units were shut down. The 242-T Evaporator was reactivated in December 1965, and shut down again in April 1976.

(9) Currently inoperative. These two in-tank solidification (ITS) units accomplished in-tank heating. ITS Unit \#l started up March 1965, and ITS Unit 2 started up February 1968. In August 1971, ITS Unit 1 was converted from an evaporator to a cooler for ITS Unit 2. Both units were shut down June 1974 . 
TABLE D-1. Performance Summary. (sheet 3 of 3 )

(10) Currently inoperative. The 242-S Evaporator-Crystallizer was started up November 1973, and shut down March 1980, when its processing project was completed. It is in standby mode with no future mission. This evaporator operates under a vacuum, employing evaporative concentration with subsequent crystallization and precipitation of salt crystals.

(11) Currently inoperative. The 242-A Evaporator-Crystallizer was started up March 1977, and shut down April 1989 because of regulatory issues, and has remained shut down for subsequent upgrading. It is planned that the upgrade will be completed and the evaporator restarted in December 1991. This evaporator operates under a vacuum, employing evaporative concentration with subsequent crystallization and precipitation of salt crystals.

(12) Currently inoperative. Additional concentration of wastes was obtained by using the concentrators at REDOX and B Plant. The REDOX concentrator was used from July 1967 to June 1972, while the B Plant concentrator was used from July 1967 to February 1968. 
WHC-EP-0182-40

This page intentionally left blank. 
WHC-EP-0182-40

\section{APPENDIX E}

\section{LIQUID STATUS AND PUMPABLE LIQUID} REMAINING IN TANKS 
WHC-EP-0182-40

This page intentionally left blank. 


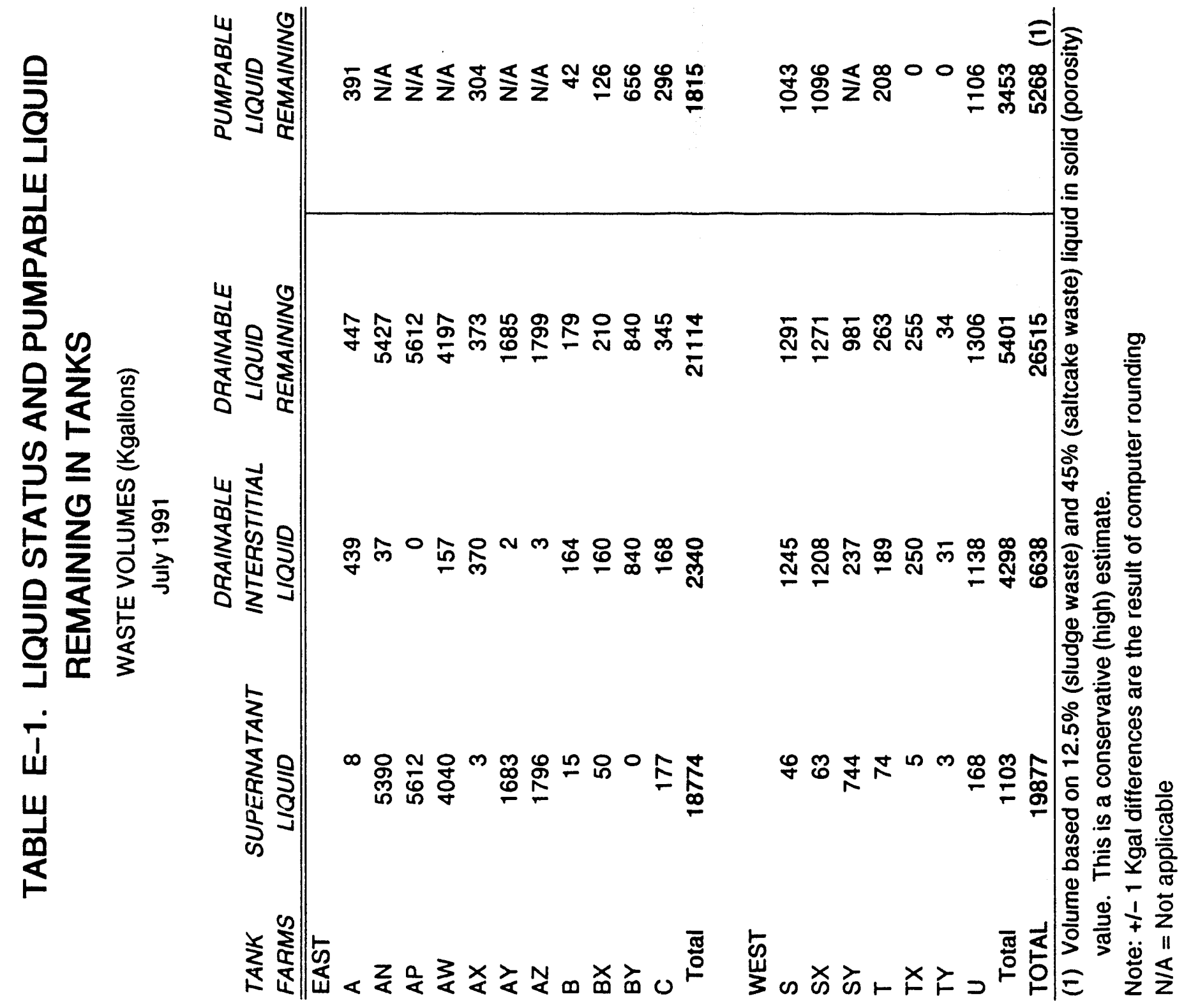


WHC-EP-0182-40

This page intentionally left blank. 
WHC-EP-0182-40

APPENDIX F

PUMPING RECORD

F-1 
WHC-EP-0182-40

This page intentionally left blank. 


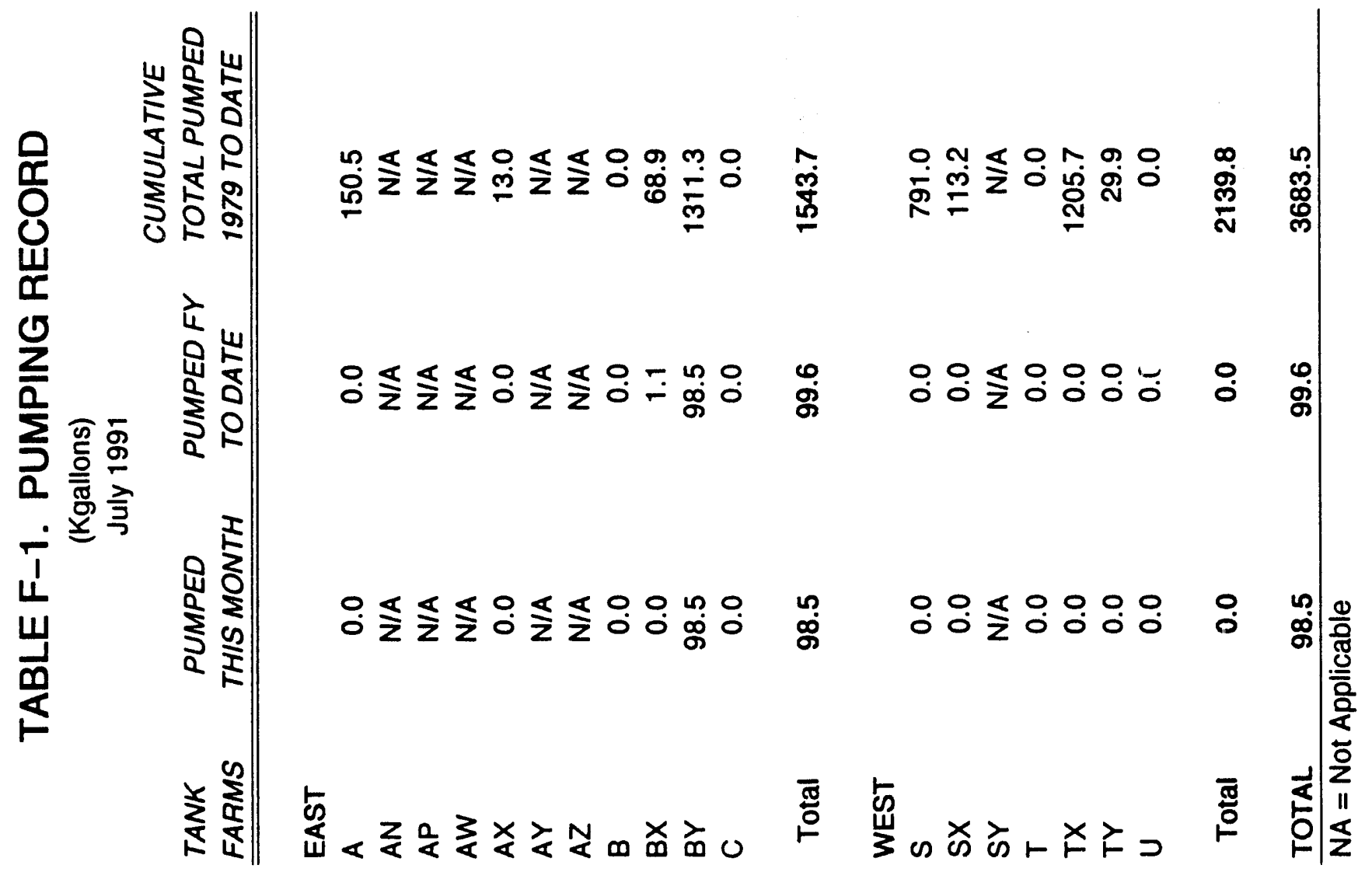


WHC-EP-0182-40

This page intentionally left blank. 
WHC-EP-0182-40

APPENDIX G

CATCH TANKS AND SPECIAL SURVEILLANCE FACILITIES

G-1 
WHC-EP-0182-40

This page intentionally left blank. 


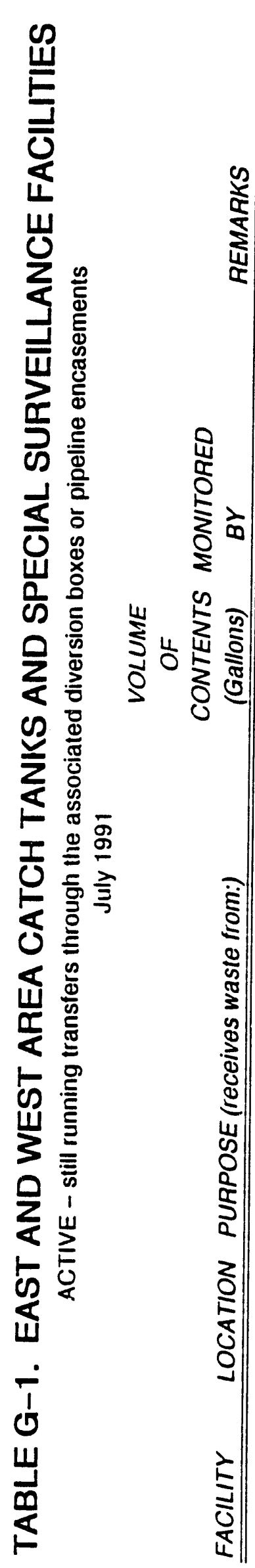

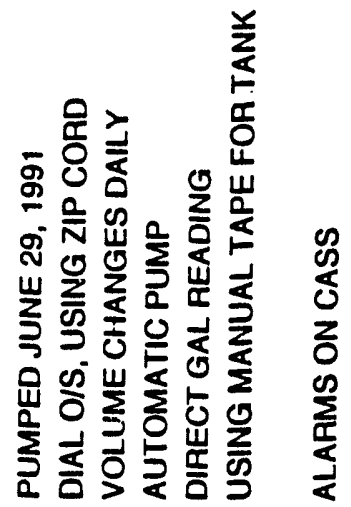

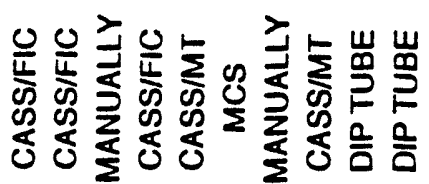

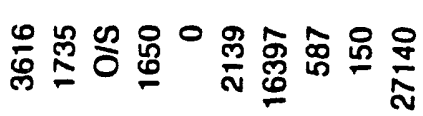

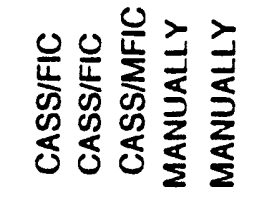

窇苍

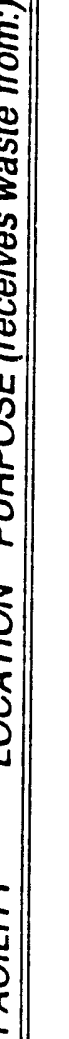

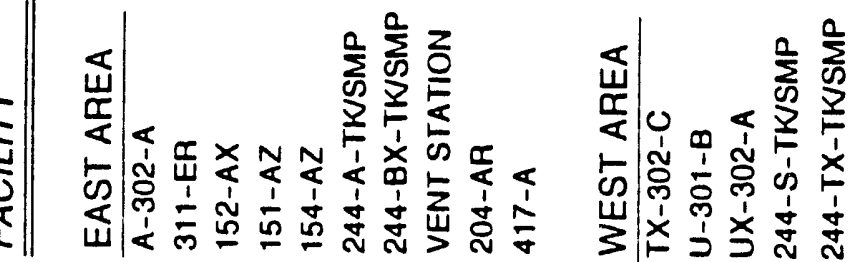

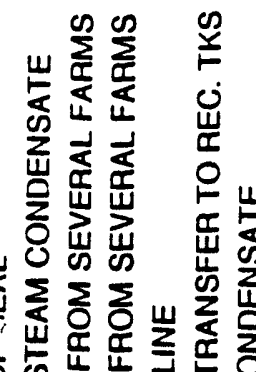

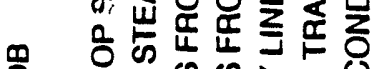

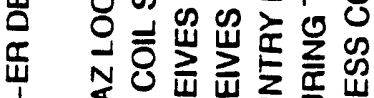

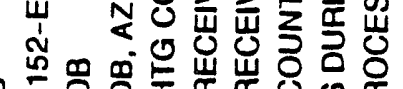

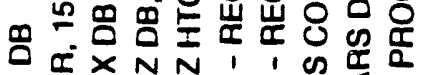

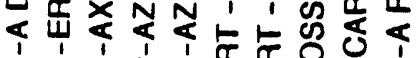

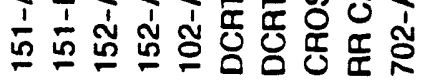

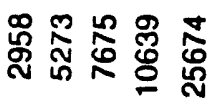

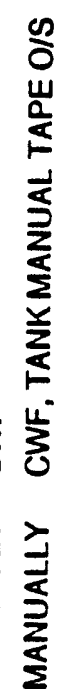

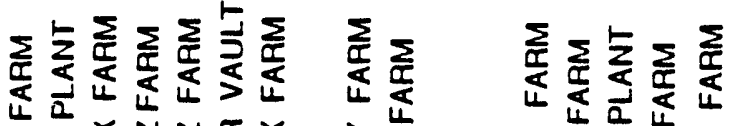

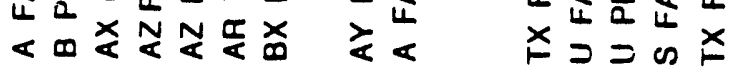

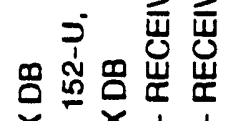

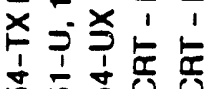

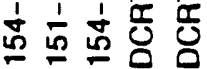
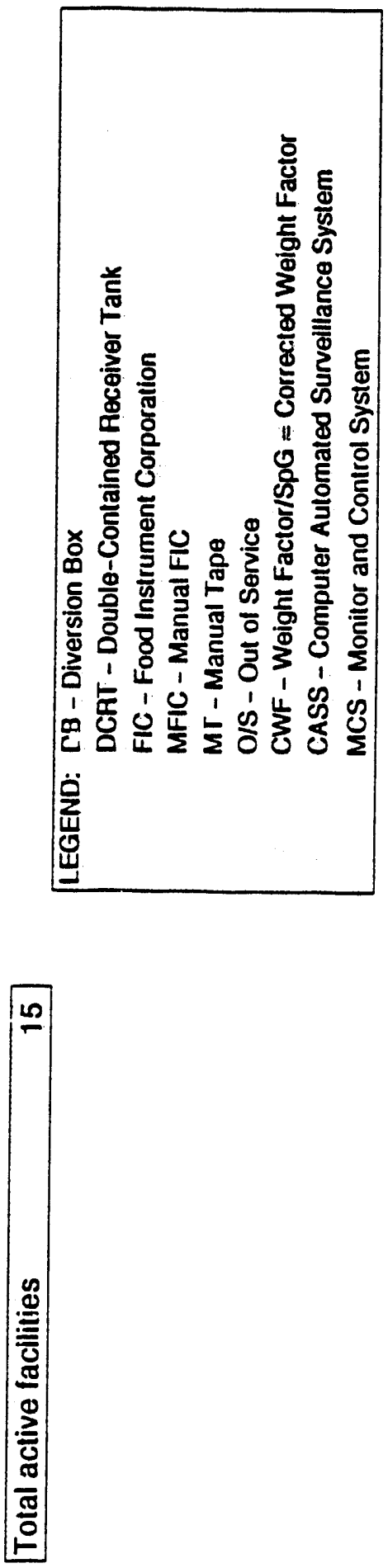
WHC-EP-0182-40

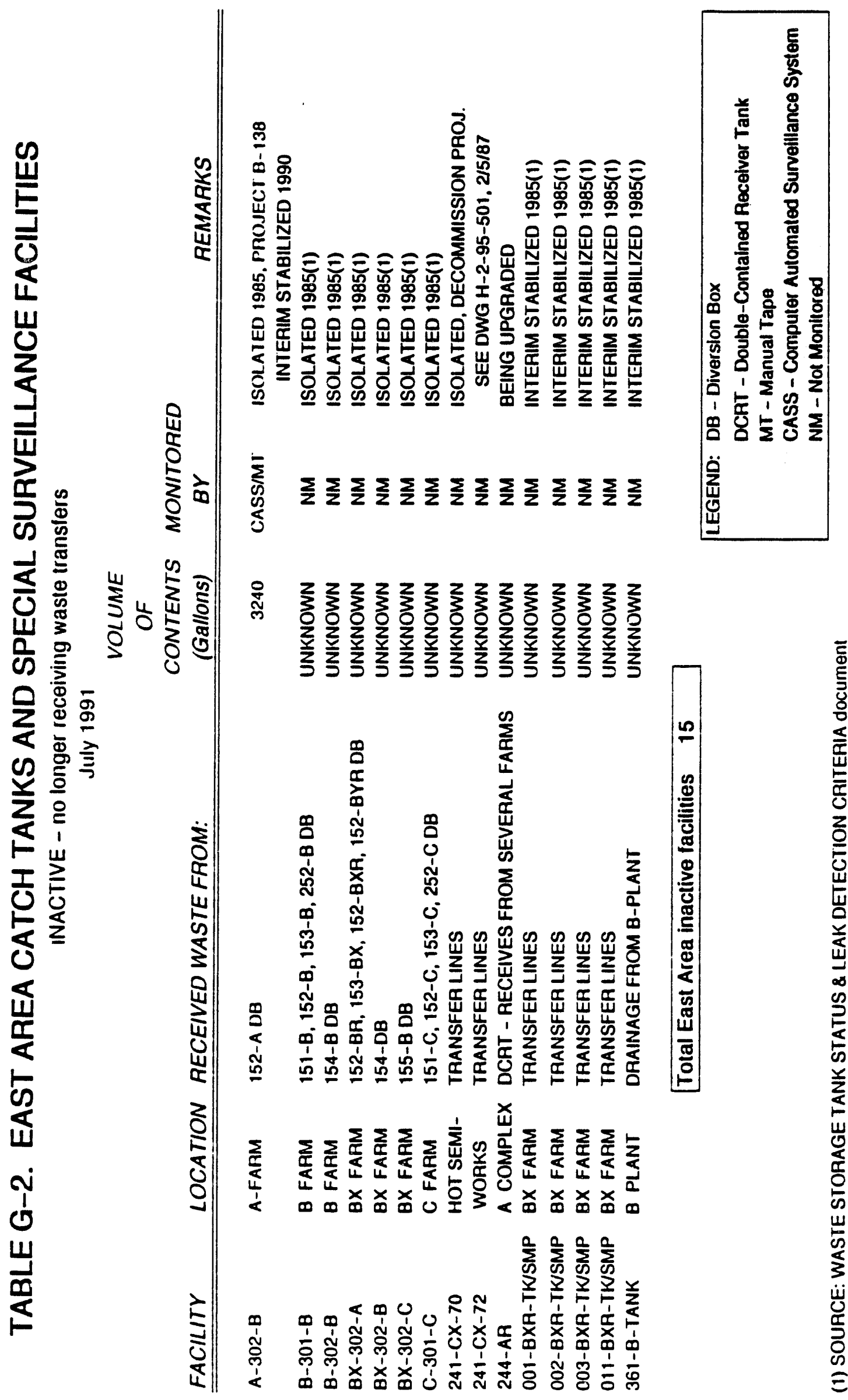


WHC-EP-0182-40

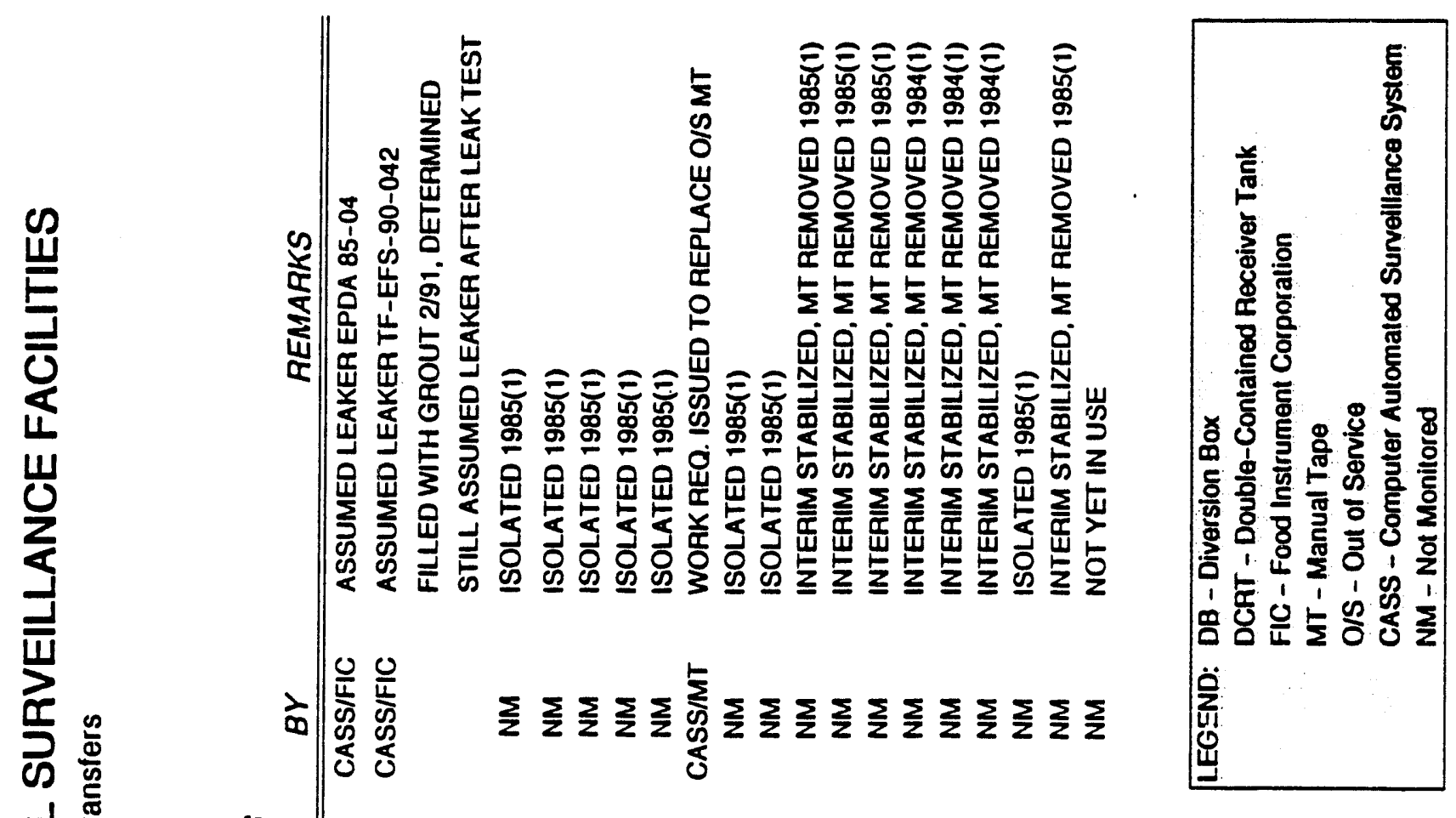

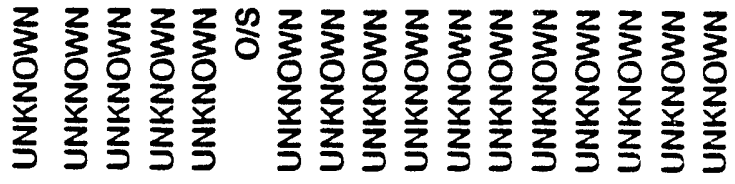

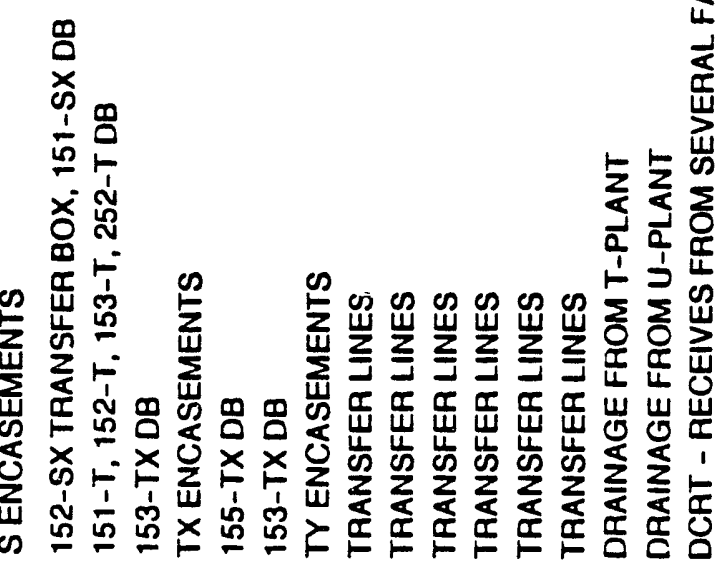

㟧

3

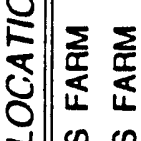

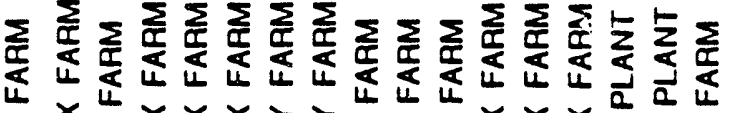

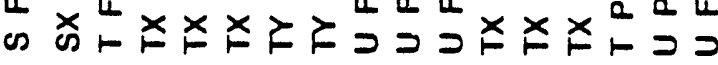

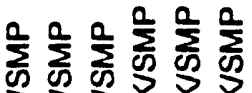

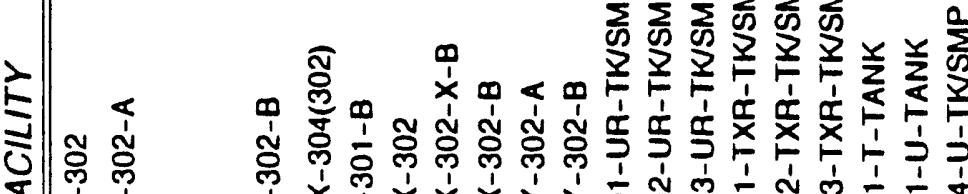
प्रा|ण के

倇

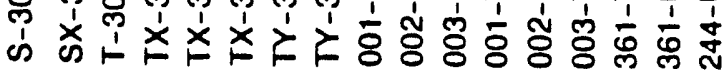


WHC-EP-0182-40

This page intentionally left blank.

G-6 
WHC-EP-0182-40

\section{APPENDIX H}

\section{LEAK VOLUME ESTIMATES}

H-1 
WHC-EP-0182-40

This page intentionally left blank. 
TABLE H-1. LEAK VOLUMES ESTIMATED AND REPORTED BEFORE 1989 (39 Tanks) (5) (Sheet 1 of 2)

\begin{tabular}{|c|c|c|c|c|}
\hline TANK & $\begin{array}{c}\text { LEAK } \\
\text { IDENTIFIED (3) }\end{array}$ & $\begin{array}{l}\text { VOLUME (2) } \\
\text { (Gallons) }\end{array}$ & $\begin{array}{l}\text { ASSOCIATED } \\
137 \mathrm{CS}(4)\end{array}$ & $\begin{array}{r}\text { INTERIM } \\
\text { STABILIZED }\end{array}$ \\
\hline $241-A-103$ & 1987 & 5500 & & $8 / 88$ \\
\hline $241-A-104$ & 1975 & 2500 & & $9 / 78$ \\
\hline $241-A-105$ & 1963 & 5000 (1) & & $7 / 79$ \\
\hline $241-A X-102$ & 1988 & 3000 & & 9/88 \\
\hline $241-B-107$ & 1980 & 8000 & & $3 / 85$ \\
\hline $241-B-110$ & 1981 & 10000 & & $12 / 84$ \\
\hline $241-B-201$ & 1980 & 1200 & & $8 / 81$ \\
\hline $241-B-203$ & 1983 & 300 & & $6 / 84$ \\
\hline $241-B X-102$ & 1971 & 70000 & 50000 & $11 / 78$ \\
\hline $241-8 X-108$ & 1974 & 2500 & 500 & $7 / 79$ \\
\hline $241-B Y-103$ & 1973 & $<5000$ & & N/A \\
\hline $241-B Y-108$ & 1972 & $<5000$ & & $2 / 85$ \\
\hline $241-C-101$ & 1980 & 20000 & & $11 / 83$ \\
\hline $241-C-201$ & 1988 & 550 & & $3 / 82$ \\
\hline $241-C-202$ & 1988 & 450 & & $8 / 81$ \\
\hline $241-C-203$ & 1984 & 400 & & $3 / 82$ \\
\hline $241-C-204$ & 1988 & 350 & & $9 / 82$ \\
\hline $241-S X-104$ & 1988 & 6000 & & N/A \\
\hline $241-S X-107$ & 1964 & $<5000$ & & $10 / 79$ \\
\hline $241-S X-108$ & 1962 & 2400 & 20000 & $8 / 79$ \\
\hline $241-S X-109$ & 1965 & 5000 & & $5 / 81$ \\
\hline $241-S X-110$ & 1976 & 5500 & & $8 / 79$ \\
\hline $241-S X-111$ & 1974 & 2000 & 2000 & $7 / 79$ \\
\hline $241-S X-112$ & 1969 & 30000 & 40000 & $7 / 79$ \\
\hline $241-S X-113$ & 1962 & 15000 & 8000 & $11 / 78$ \\
\hline $241-S X-115$ & 1965 & 50000 & 40000 & $9 / 78$ \\
\hline $241-T-106$ & 1973 & 115000 & 40000 & $8 / 81$ \\
\hline $241-T-108$ & 1974 & $<1000$ & & $11 / 78$ \\
\hline $241-T-111$ & 1984 & $<1000$ & & N/A \\
\hline $241-T X-107$ & 1984 & 2500 & & $10 / 79$ \\
\hline $241-T Y-101$ & 1973 & $<1000$ & & $8 / 83$ \\
\hline $241-T Y-103$ & 1973 & 3000 & 700 & $2 / 83$ \\
\hline $241-T Y-104$ & 1981 & 1400 & & $1 / 83$ \\
\hline $241-T Y-105$ & 1960 & 35000 & 4000 & $2 / 83$ \\
\hline $241-T Y-106$ & 1959 & 20000 & 2000 & $11 / 78$ \\
\hline $241-U-101$ & 1959 & 30000 & 20000 & $9 / 79$ \\
\hline $241-U-104$ & 1961 & 55000 & 90 & $10 / 78$ \\
\hline $241-U-110$ & 1975 & 8100 & & $12 / 84$ \\
\hline $241-U-112$ & 1980 & 8500 & & 9/78 \\
\hline Subtotal & & 542000 & anks) & \\
\hline
\end{tabular}


TABLE H-1. Leak Volumes Estimated and Reported Before 1989 (39 Tanks). (sheet 2 of 2)

\section{Footnotes:}

(1) Perhaps as much as 1 Mgal of clean cooling water was sprayed into single-shell Tank 241-A-105 in the 1970's to aid in evaporative cooling. It is likely that much of this water $(50,000$ to $800,000 \mathrm{gal})$ did not evaporate and, therefore, may have leached or entrained some of the sludge and added to the waste released from this tank. In accordance with Washington Administrative Code 173-303-070 (2)(a)( $\left.i)^{1}\right)^{1}$, this leachate is also a waste. Past practice was to exclude the cooling water from the leak volume estimate. This practice has been continued in current reports for the following reasons:

1. Estimates of cooling water additions have varied from approximately 100,000 gal up to $1.5 \mathrm{Mgal}$

2. There is no accurate method to estimate the amount of cooling water that leaked from the tank (as of October 1990, the estimates ranged from 50,000 to $800,000 \mathrm{gal}$ )

3. There is no method to accurately determine the amount of additional waste that was released by being dissolved or entrained from the cooling water that leaked from the tank. The waste content (concentration) in the cooling water that leaked should be less than in the original liquid waste in the tank (the sludge is relatively insoluble).

(2) These volumes do not include (with some exceptions) such things as (a) cooling/raw water leaks; (b) intrusions (rain infiltration) and subsequent leaks; (c) leaks inside the tank farm but not through the tank liner (surface leaks, pipeline leaks, leaks at the joint for the overflow or fill lines, etc.); and (d) leaks from catch tanks, diversion boxes, encasements, etc.

(3) In many cases a leak was suspected long before it was identified or confirmed. In 1984, the criteria designations of "suspected leaker," "questionable integrity," and "confirmed leaker" were merged into one category now reported as "assumed leaker."

(4) Source: ERDA-1538 (Final Environmental Statement, Waste Management). The ${ }^{137} \mathrm{Cs}$ leakage can be used to estimate the amount of other radionuclides leaked.

(5) There is effort currently in progress to reevaluate these leak volume estimates.

'WAC, 1989, Dangerous Waste Regulations, Washington Administrative Code 173-303, Hashington State Departiment of Ecology, 01ympia, Washington. 
TABLE H-2. LEAK VOLUMES ESTIMATED IN 1989 (27 Tanks)

\begin{tabular}{|c|c|c|c|}
\hline TANK & $\begin{array}{c}\text { LEAK } \\
\text { IDENTIFIED }\end{array}$ & $\begin{array}{l}\text { VOLUME } \\
\text { (Gallons) }\end{array}$ & $\begin{array}{c}\text { INTERIM } \\
\text { STABILIZED }\end{array}$ \\
\hline 241-B-204 & 1984 & 400 & $6 / 84$ \\
\hline $241-B Y-107$ & 1984 & 15100 & $7 / 79$ \\
\hline $241-C-111$ & 1968 & 5500 & $3 / 84$ \\
\hline $241-S-104$ & 1968 & 24000 & $12 / 84$ \\
\hline $241-T-103$ & 1974 & $<1000$ & $11 / 83$ \\
\hline $241-T-109$ & 1974 & $<1000$ & $12 / 84$ \\
\hline Subtotal & & 47000 & (6 Tanks) \\
\hline $241-B-112$ & 1978 & 2000 & $5 / 85$ \\
\hline $241-C-110$ & 1984 & 2000 & N/A \\
\hline Subtotal & & 4000 & (2 Tanks) \\
\hline $241-A X-104$ & 1977 & -- & $8 / 81$ \\
\hline 241-B-101 & 1974 & -- & $3 / 81$ \\
\hline $241-B-103$ & 1978 & -- & $2 / 85$ \\
\hline 241-B-105 & 1978 & -- & $12 / 84$ \\
\hline $241-B-111$ & 1978 & -- & $6 / 85$ \\
\hline $241-B X-101$ & 1972 & -- & $9 / 78$ \\
\hline $241-B X-110$ & 1976 & -- & $8 / 85$ \\
\hline $241-B X-111$ & 1984 & -- & N/A \\
\hline $241-B Y-105$ & 1984 & -- & N/A \\
\hline $241-B Y-106$ & 1984 & -- & N/A \\
\hline $241-S X-114$ & 1972 & -- & $7 / 79$ \\
\hline $241-T-107$ & 1984 & -- & N/A \\
\hline 241-TX-105 & 1977 & -- & $9 / 83$ \\
\hline $241-T X-110$ & 1977 & -- & $4 / 83$ \\
\hline $241-T X-113$ & 1974 & -- & $4 / 83$ \\
\hline $241-T X-114$ & 1974 & -- & $4 / 83$ \\
\hline 241-TX-115 & 1977 & -- & $9 / 83$ \\
\hline $241-T X-116$ & 1977 & -- & $4 / 83$ \\
\hline $241-T X-117$ & 1977 & -- & $3 / 83$ \\
\hline Subtotal & & 150000 & (a) (19 Tanks) \\
\hline Subtotal & & 201000 & Table G-2 \\
\hline Subtotal & & 542000 & Table G-1 \\
\hline TOTAL & & 750000 & (b) \\
\hline
\end{tabular}

(a) Estimate rounded to nearest 10000 gal.

(b) Rounded to nearest $50000 \mathrm{gal}$.

$\mathrm{N} / \mathrm{A}=$ not applicable (not yet interim stabilized) 
WHC-EP-0182-40

This page intentionally left blank.

$H-6$ 


\section{DISTRIBUT ION}

Number of copies

\section{OFFSITE}

7

U.S. Department of Energy-Headquarters 1000 Independence Avenue SW Washington, D.C. 20585
A. Griffith
R. Hansen
G. Hardcastle
J. S. Kang
J. C. Lehr
J. C. Tseng
H. F. Walter

EM-322

$E H-361$

TREV/II/343

EH-222

GTN $/ \mathrm{J}-112$

EM-351

EM-442

$E M-35$

EM-343 FORS / 3G-089

TREV I I $/ 368$

TREV II $/ 160$

TREV II $/ 366$

U.S. Department of EnergyOak Ridge Operations office

P. 0. Box 2001

Oak Ridge, TN 37831

W. D. Adams

$\mathrm{EW}-40$

$4 \quad$ U.S. Department of Energy-

Savannah River Site

P. 0. Box A

Aiken, SC 29802

C. Anderson

C. W. Terrell

L. Sjostrom

V. Wheeler

707-H, Room 3

704-S

704-S

$3 \quad$ U.S. Department of Energy-

Idaho Operations

785 D.0.E. Place

Idaho Falls, ID 83402

C. Enos

J. E. Solecki

MS -1139

G. Woodall

MS -115

MS-1139

1 Oregon State Water Resources

Department

Ground Water Hanford Studies

3850 Port land Road

Salem, OR 97310

R. 0. Patt 


$$
\begin{gathered}
\text { WHC-EP-0182-40 } \\
\text { Distribution (continued) }
\end{gathered}
$$

\section{Number of copies}

\section{OFFSITE}

1

Washington State Department of

Ecology

OTympia, WA 98504-8711

R. Stanley

PV-11

1

Washington State Department of Health Radiation Protection Section Industrial Park Building 5

01ympia, WA 98504

A. Conklin

1

Massachusetts Institute of Technology

77 Massachusetts Avenue

Cambridge, MA 02139

Mujid S. Kazimi

Professor and Head

Department of Nuclear Engineering

3

Los Alamos National Laboratory

P. 0. Box 1663

Los Alamos, NM 87545

T. Larson

C-920

A. Nuels

H. Sulliva

$\mathrm{N}-6$

N-6

3

Oak Ridge National Laboratories

P. 0. Box 2008

Oak Ridge, TN 37831

D. 0. Campbe 11

MS -6268

C. Forsberg

MS-6273

T. S. Kress

MS-8088

1

Lawrence Livermore National Laboratory Box 808, East Avenue

Livermore, CA 94550

B. C. Hudson 


$$
\begin{gathered}
\text { WHC-EP-0182-40 } \\
\text { Distribution (continued) }
\end{gathered}
$$

\section{Number of copies}

\section{OFFSITE}

2

Brookhaven National Laboratory

Building 129

Upton, NY 11973

K. K. Bandyopadhyay

M. Reich

Sandia National Laboratories

Department 6463, 1515 Eubank, NE A1 buquerque, NM 87185

Scott Slezak

2

BDM International. Inc. 20030 Century Blvd, Suite 101 Germantown, MD 20874

P. Kiang

K. J. Mahoney

2

SAIC

20030 Century Blvd, Suite 201 Germantown, MD 20874

R. S. Daniels

J. R. Pearring

1

SAIC

1845 Terminal Drive, Suite 130 Richland, WA 99352

J. Michima

1

Harvard School of Public Health 665 Huntington Avenue Boston, MA 02115

M. First

1

Air Products and Chemicals, Inc. 7201 Hamilton Blvd. Allentown, PA 18195

G. Schmauch 
WHC-EP-0182-40

Distribution (continued)

Number of copies

\section{OFFSITE}

2

West Valley

P. 0. Box 191

West Valley, NY 14171

S. Ketola

D. K. Ploetz

MS-191

MS-305

General Accounting office

P. 0. Box 321

Richland, WA 99352

C. R. Abraham

2

\section{Defense Nuclear Facilities}

Safety Board

625 Indiana Ave, N.W.

Washington, D.C. 20004

Dan Burnfield

Dermot M. Winters, Geological Engineer

1

Westinghouse Idaho Nuclear Corporation

P. 0. Box 4000

Idaho Falls, ID 83403-4000

A. P. Hoskins

MS -5217

2

Westinghouse Savannah River Co.

Building 703-H

P. 0. Box 616

Aiken, SC 29802

P. D. d'Entremont

W. R. West

703-H

704-8H

1

C. Abrams

1987 Virginia Drive

Idaho Falls, ID 83404

1

F. Carlson

6965 North, 5th West

Idaho Falls, ID 8340 I

Distr-4 
WHC-EP-0182-40

Distribution (contirued)

\section{Number of copies}

\section{OFFSITE}

1

1

12

6
Joseph J. DiNunno, Engineering Consultant

44 Carriage Lane

Annapolis, MD 21401

D. Oakley

40912 th Street, SW, \#310

Washington, D.C. 20024

National Research Council. National

Academy of Sciences

2101 Constitution Ave., N. W.

Washington D.C. 20418

Robert S. Andrews, Senior Staff Officer

Board on Radioactive Waste Management

Waste Management External Advisory

Committee Members

Dr. Frank L. Parker

Professor of Environmental and Water Resources

Engineering

Vanderbilt University

P. 0. Box 1596, Station B

Nashville, TN 37235

Dr. Bruce R. Kowalski

Professor of Chemistry, Co-director of Center for Process Analytical Chemistry

University of Washington

Chemistry Department, B1dg 10

Seattle, WA 98195

Dr. Greg R. Choppin

Professor of Chemistry

Florida State University

Department of Chemistry, B-164

Tallahassee, FL 32306

Dr. Chester Grelecki

President, Chief Scientist

Hazards Research Corporation

200 Valley Road

Mt. Arlington, NJ 07856 


$$
\begin{gathered}
\text { WHC-EP-0182-40 } \\
\text { Distribution (continued) }
\end{gathered}
$$

Number of copies

\section{OFFSITE}

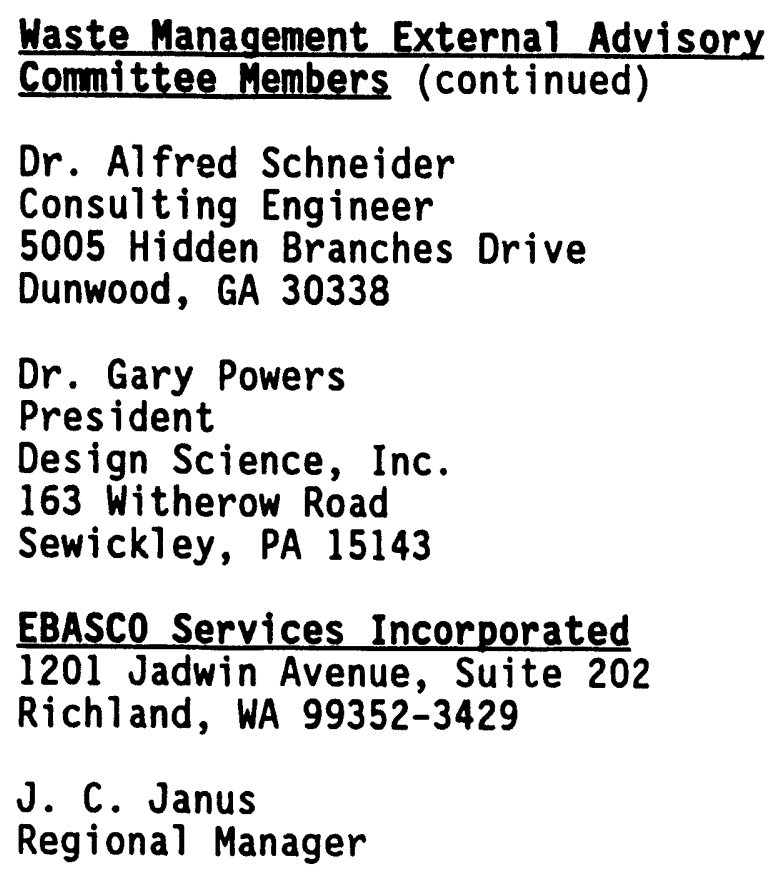

\section{ONSITE}

U.S. Department of Energy Field Office, Richland

G. E. Bishop

R2-62

G. J. Bracken

R4-04

R. E. Gerton

W. F. Hendrickson

A4-02

R. D. Hildebrand

A4-02

J. E. Little

A5-55

K. L. Morgan

A5-22

J. E. Newson

A7-75

G. W. Rosenwald

R2-62

R. Sweeney

A4-02

A. D. Toth

A4-02

Reading Room

R2-62

Al-65

Stone and Webster Engineering Co.

E. L. Richards 
WHC-EP-0182-40

Distribution (continued)

Number of copies

ONSITE

9

Pacific Northwest Laboratory

L. L. Burger

D. H. Denham (2)

L. C. Morgan

P7-25

R. D. Scheele

A3 -60

P. A. Scott

P7-25

J. C. Spanner

P7 -44

J. R. Weber

K2-05

R. S. Wegeng

K3-53

R6-31

Westinghouse Hanford Company

A. T. Alstad

R1-49

J. D. Anderson

N3-11

H. Babad

D. L. Becker

H4-23

D. B. Bechtold

H5-57

M. L. Bell

M. V. Berriochoa

T6-50

H4-23

D. C. Board (3)

B3-30

K. D. Boomer

G. L. Borsheim

S1-57

H5-49

V. C. Boyles

R2-11

D. R. Bratzel

R1-49

S. A. Bryan

T6-50

W. W. Burk

P7-25

J. G. Burk, Jr.

L6-13

J. H. Bussell

B3-25

K. G. Carothers

L7-05

R. J. Cash

$\mathrm{R} 1-51$

G. Christensen

$\mathrm{H} 4-23$

W. L. Cowley

$\mathrm{H} 4-23$

D. S. Cunningham

$\mathrm{H} 5-31$

SO-02

G. M. Crummel

R1-51

J. E. Dearing

H5-58

D. E. Deaton

SO- 04

J. L. Deichman

$\mathrm{H} 4-23$

D. R. Üickinson

L5-31

R. A. Dodd

R1-51

G. T. Dukelow

R2-97

G. L. Dunford

R1-51

J. A. Eaker

R1-51

W. G. Farley

H5-32

K. 0. Fein

$\mathrm{H} 5-34$

K. D. Fowler

R2-11 
WHC-EP-0182-40

Distribution (continued)

Westinghouse Hanford Company (continued)

G. L. Fox, Jr.

L5-01

G. T. Frater

R1-51

J. R. Freeman-Poll ard

H4-55

K. A. Gasper

H4-23

G. J. Gauck

R2-07

R. L. Gilchrist

L5-63

S. D. Godfrey

D. J. Green

W. 0 . Greenhalgh

V. W. Hall

R1-51

D. G. Hamrick

B. M. Hanlon (25)

H5-53

L5-31

L4-88

J. M. Hanson

R1-51

R1-80

H. D. Harmon

R2-40

J. M. Henderson

R2-52

SO-09

D. W. Hendrickson

R4-03

E. G. Hess

R3-09

$M . C$. Higginson

A4-25

J. G. Hill

R. C. Hill

R2-12

$\mathrm{H} 4-23$

N. A. Homan

H4-52

B. K. Horsager

S4-68

R. D. House

R2-83

K. J. Hul1

J. E. Hysjulien

M. N. Islam

G. D. Johnson

J. L. Juette

L. J. Julyk

S. E. Kelly

H5-71

H5-09

R3-80

H4-23

55-11

H5-53

R2-12

N. W. Kirch

R2-11

E. M. Koellermeier

N1-29

G. M. Koreski

M. Kummerer

E. L. Kunkler

$D$. L. Lenseigne

S. Marchetti

R. M. Marusich

R1-51

H5-32

H5- 10

R2-75

R2-50

H5-32

V. D. Maupin

R1-49

J. D. McCormack

L5-31

D. E. McKenney

R1-48

T. E. Mensinger

RI-08

N. R. Miller

B3-55

W. J. Millsap

H5-68

L. D. Muhlestein

N1-28

B. E. Opitz

R2-83

A. Padilla, Jr.

HO-32 
WHC-EP-0182-40

Distribution (continued)

Westinghouse Hanford Company (continued)

D. B. Pabst

B2-35

T. B. Powers

HO-31

A. L. Prignano

J. G. Propson

H4-57

T. E. Rainey

R2-18

R. E. Raymond (2)

R1-49

R. W. Reed

R1-80

J. H. Roecker

R1-51

J. A. Ryan

R2-28

F. A. Schmorde

H5-57

K. V. Scott

R2-88

J. E. Shapley

H5-52

R. A. Shea

$\mathrm{N} 1-83$

E. M. Sheen

S5-11

L7-05

P. K. Shen

HO-39

L. C. Shoemaker

A. T. Shook

L6-29

S. G. Spencer

T4-10

D. D. Stepnewski

SO-09

C. M. Stout

H5-32

J. N. Strode

B2-19

D. G. Sutherland

$\mathrm{R} 1-51$

L. M. Swanson

L5-55

J. F. Thompson

J. M. Thurman

H5-34

H5-71

R1-51

S. R. Tifft

H4-57

R. E. Vandercook

S6-07

R. J. Van Vleet

H5-32

J. A. Voogd

R. K. Welty

J. C. Wiborg

R4-03

RI -80

G. R. Wilson

R3-09

$\mathrm{H} 4-23$

D. D. Wodrich

R2-23

D. E. Wood

$\mathrm{B} 2-19$

W. H. Yunker

$\mathrm{N} 1-36$

272-AW Shift Office

S5-04

Publication Services (3)

R1-08

Central Files (2)

L8-04

Tank Farms Info Center

R1-28 
WHC-EP-0182-40

This page intentionally left blank.

Distr-10 

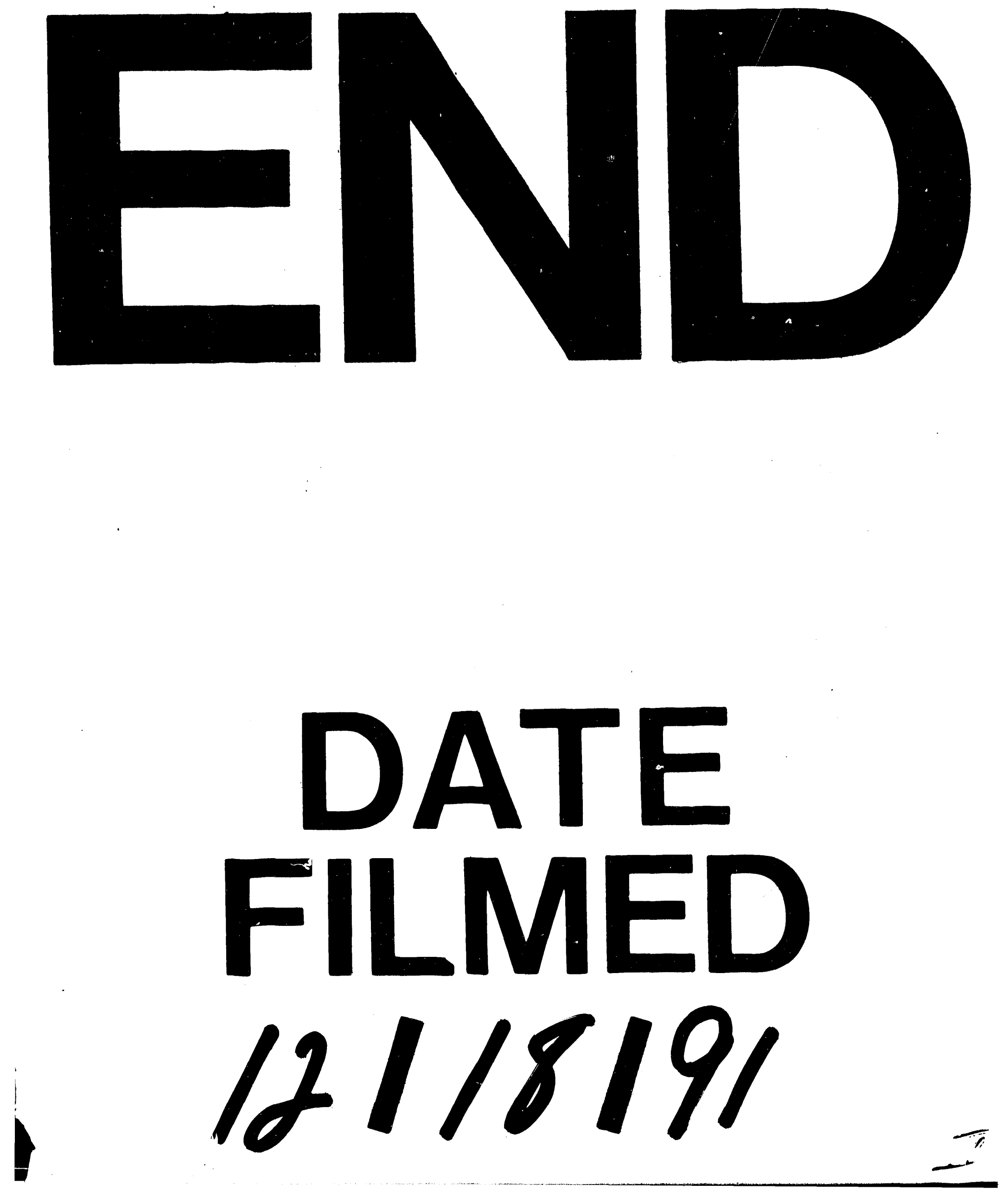
